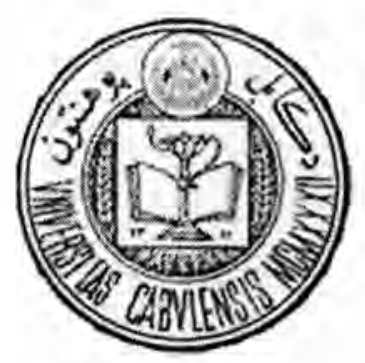

$$
\text { يوهنتون كابل }
$$

يو هنئى روانشناسى و علوم تربيتى

ديبارتمنت روانشناسى

\title{
حافظه و انواع آن
}

$$
\begin{aligned}
& \text { استاد رهنما: يوهنيار خواجه ذبيح اله صديقى } \\
& \text { ترنيب كننده: آرزو }
\end{aligned}
$$

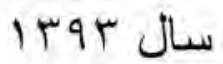




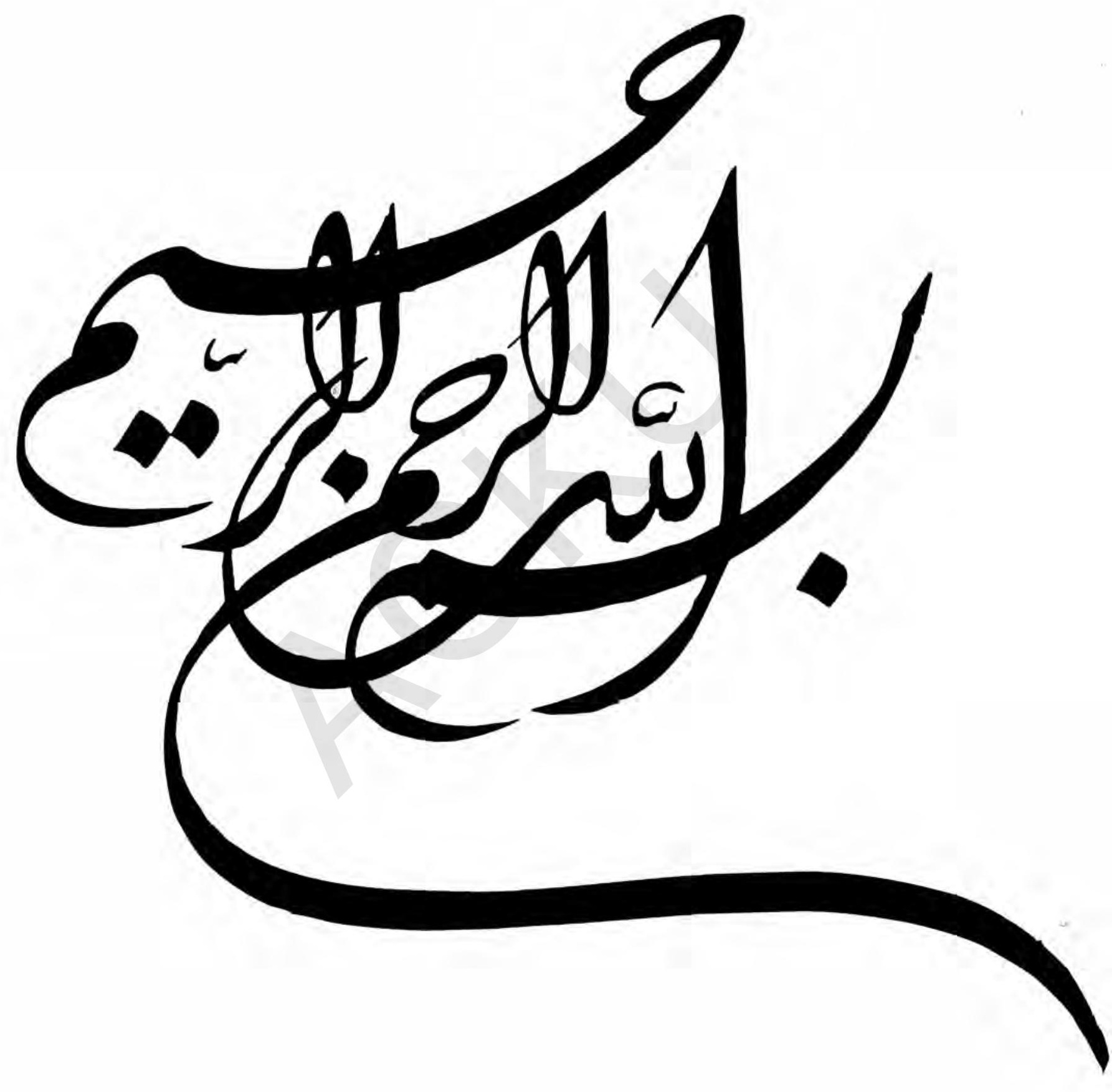




\section{يشيشتحار}

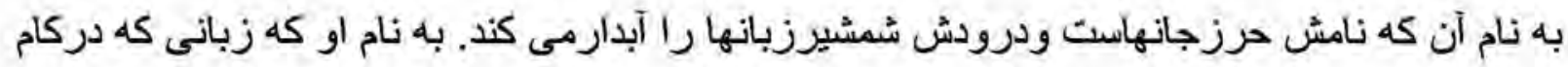

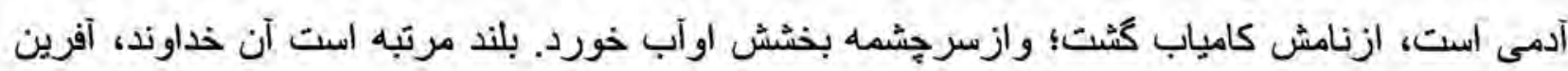

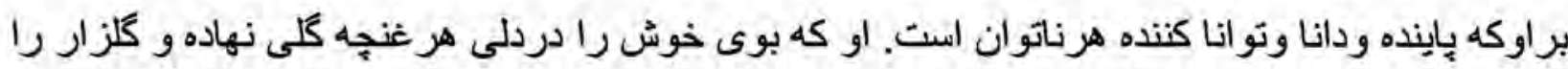

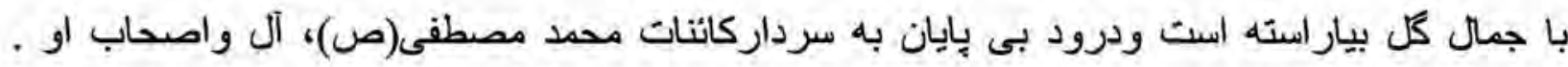

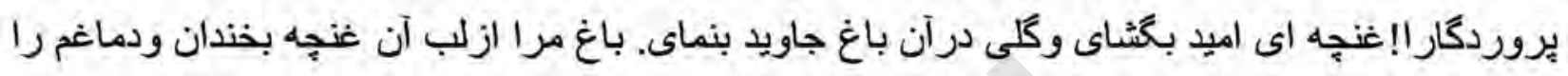

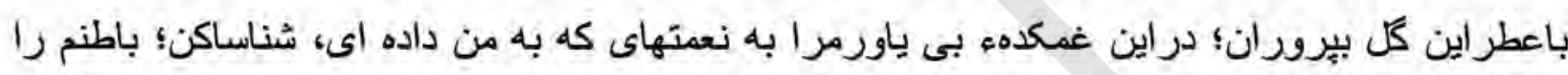
شكر كذار و زباتم را ستايشكر كردان. جاى دارد تاياد أورشوم، اين يك امر الزامى است كه مطابق رسم دانشكاهيها بعد ازختم دوره ليسانس

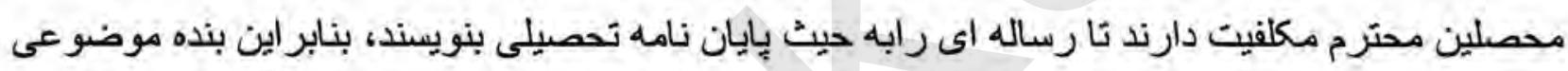

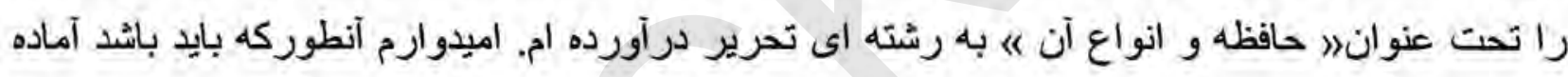
نموده واندكى به يادداشته هاى شما علم دوستان افزوده باشم.

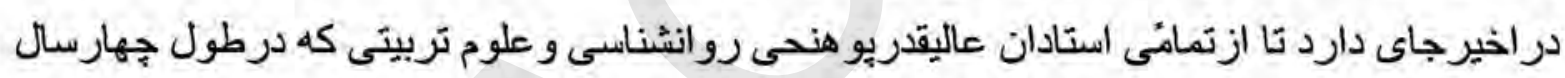

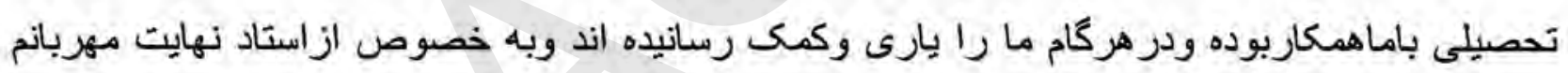

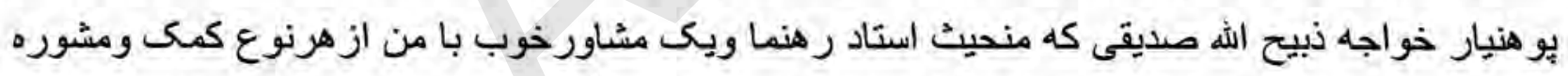

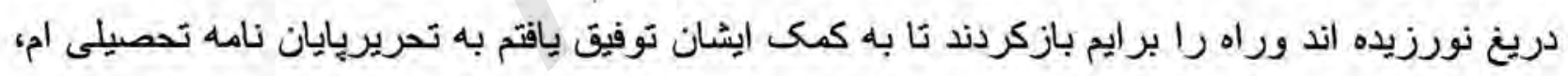

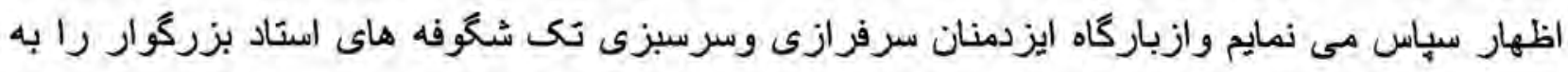
دور از زردى خزان خواسته وخواهانم.

با احترام

آرزو 


\section{فهرست مطالب}

صفحات

عناوين

1. مقدمه.. - مقا.

\section{حاقظه}

$\varepsilon$ جمع آورى اطلاعات حافظه

$\circ$ انواع حافظه

$\circ$

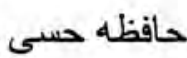

1 حافظه كوتاه مدت (S.T.M) V حافظه دراز مدث)(L.T.M)

$\wedge$ رابطه بين دو نوع حافظه كوتاه مدث و حافظه بلند مدت. 1. تقسيم بندى كلى حافظه

1. تقسيم بندى فردى حافظه.

11

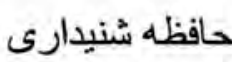

11

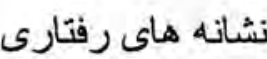

11 استفاده بهتر از حافظه شنيدارى... Ir حافظه ديدارى (بصرى). ir حافظه نوشُارى(يدى) .

\section{روشهاى تقويت حافظه}

17 جگگ نه حافظه خود را تقويت كنيم؟..

17 بر انگيختن حافظه.

17 بيست روش براى نقويت حافظه. YY راه هاى مفيد براى تقويت حافظله. ro الف ـاصول استفاده از حافظه. ry ب ـ اصول بهداشت حافظه. 
YV ج- اصول اوليه مطالعه

Y^ د ـ درك، يادكيري و يادسيازري.

rq اصول ديكر بازسازي و يادآوري.

r. تمركز تكنيك تقويت حافظه.

r) راههاى تقويت حافظه كوتاه مدت

\section{روش هاى تقويت حافظه با مواد غذاى و ويتامين ها}

rT رذريح غذابي براي ثقويت حافظه.

re خوردنى ها

r乏 ويتامين ها

r乏 ويتامين 'B و مجمو عه ويتامين هاى كروه B

r£

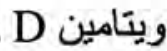

ro A ويتامين

ro تاثير ميوه هاو سبزى ها

rv تقويت حافظه از دوران جنيني..

rᄉ سرب و آلومينيوم؛ دشمنان حافظه.

rᄉ تقويت حافظه به كمك خور اكي هاي رنكارنح

rq هواي آلوده و كاهش ضريب هوشي.

\&) نتيجه كيرى $\varepsilon r$

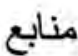




\section{مقدمبd}

حافظه به عنوان يكى از وجه امثيازات انسان به عنوان اشرف مخلوقات مى باشد. كه من را به

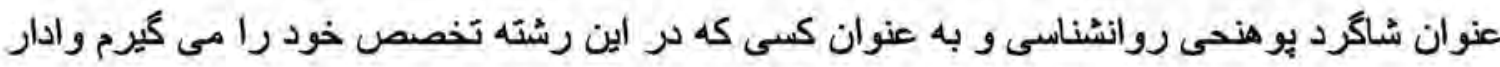

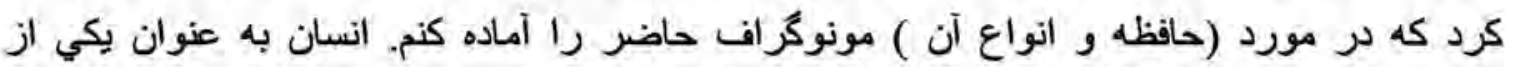

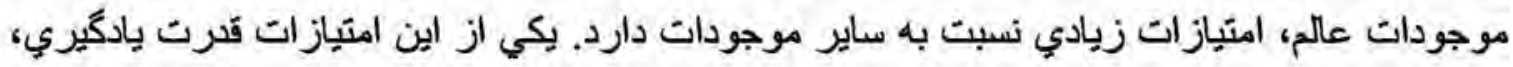

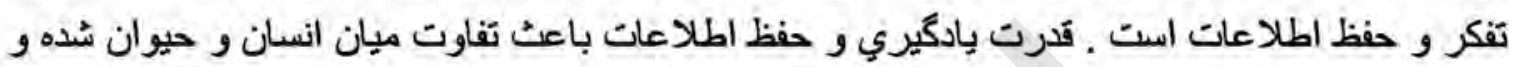
نيز برتري انسان را نسبت به ساير موجودات به اثبات رسانده است. بنابراين دركيري فكري بات بات استعداد

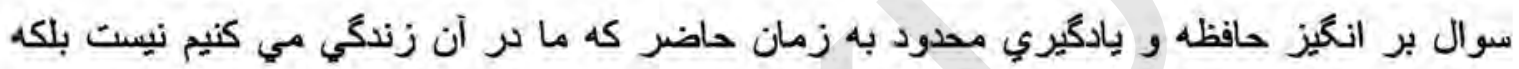

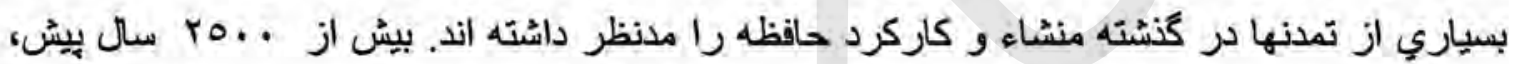

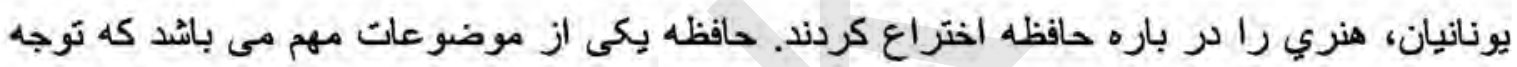

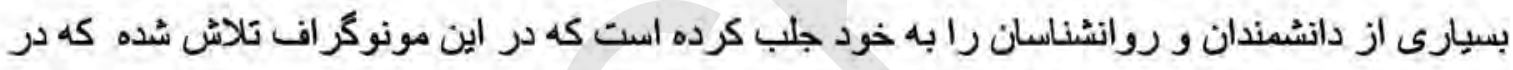
مورد حافظه و انواع آن و راه هاى براي تقويت حافظه جمع آورى شُده است.

طرح مسأله: طوريكه جامعه ما هنوز در بى سوادى و سطح بايين تعليم و تربيه به سر مى برد و آن

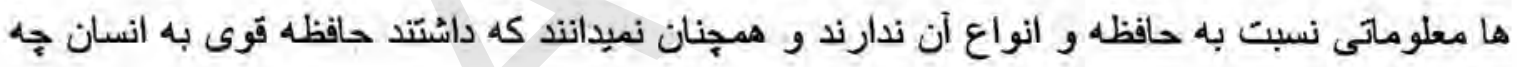

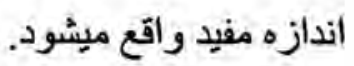

بنأ به خاطر مرك بهتر از اين بروسه مهم و نتش آن در زندگى بشر به تحرير اين موضوع عبرداختم.

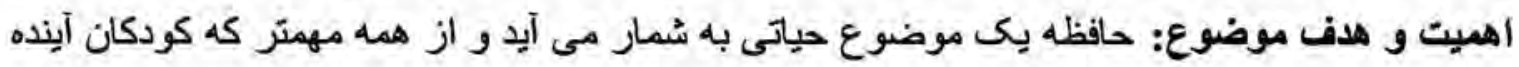

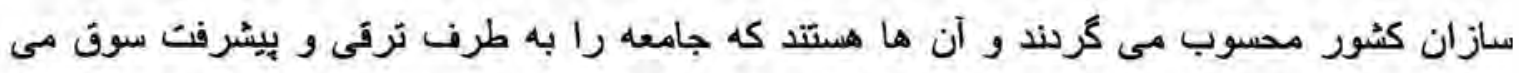

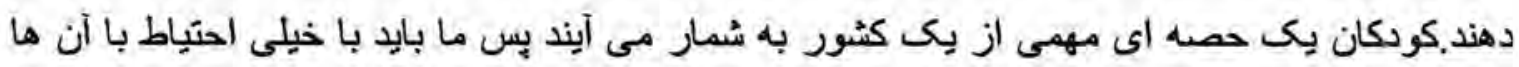

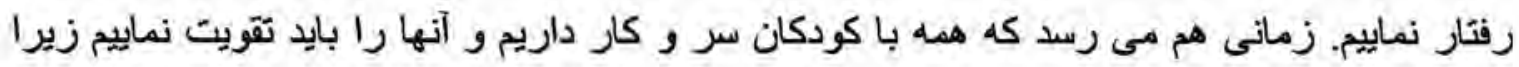

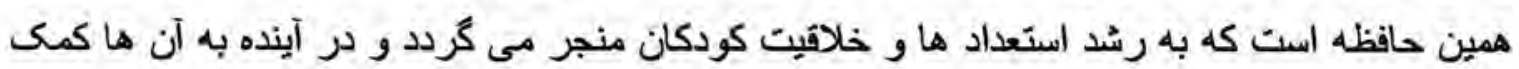

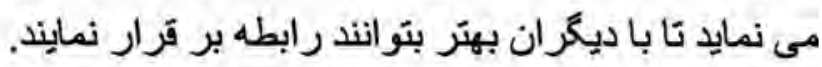

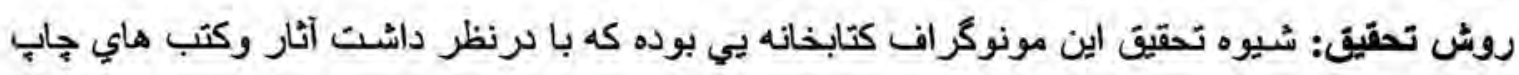

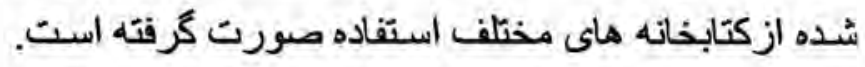

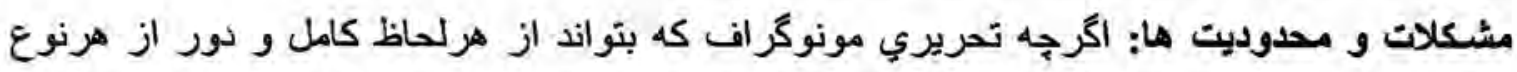

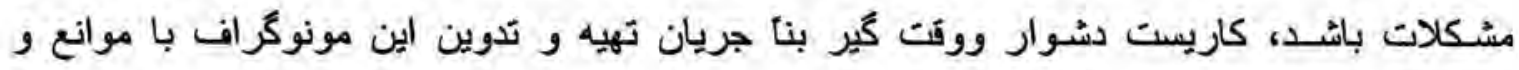


<smiles></smiles> 


\section{حافظه}

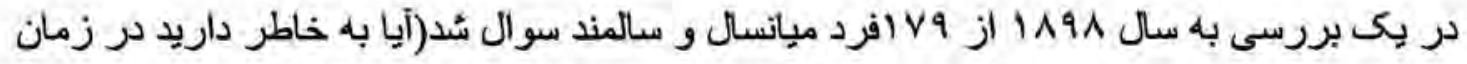

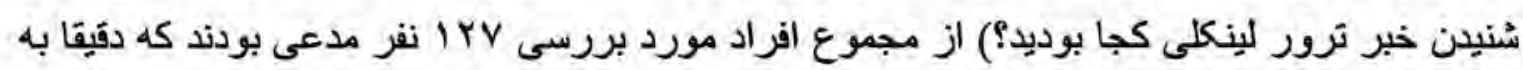

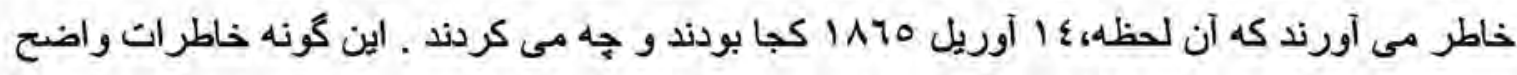

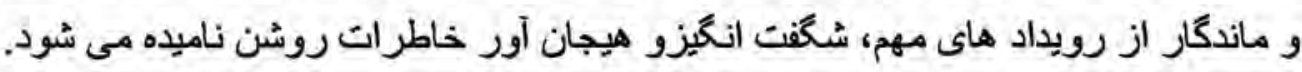

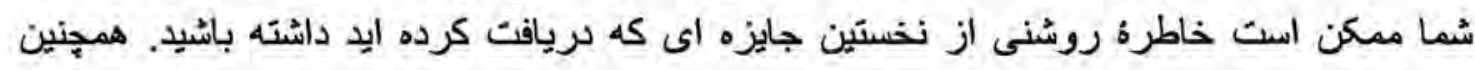

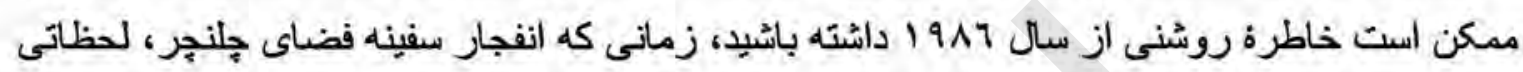

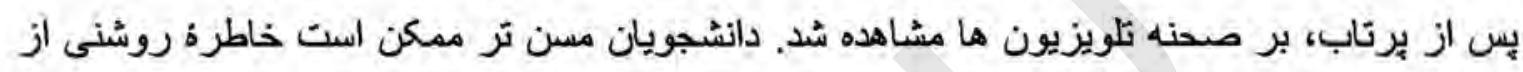

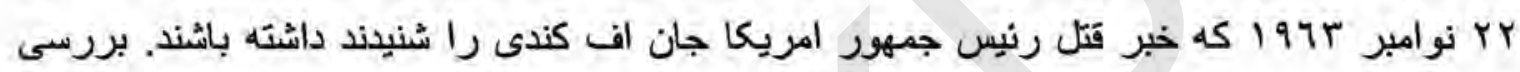

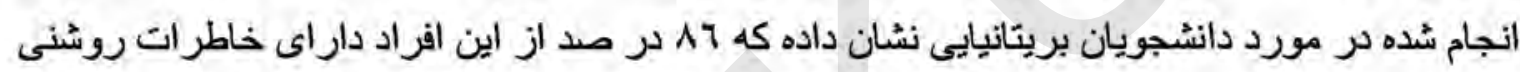

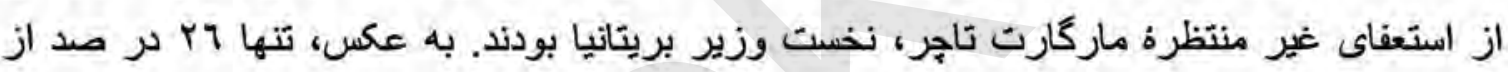

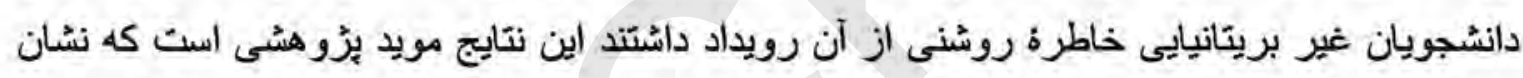

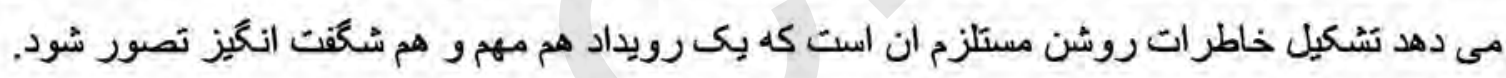

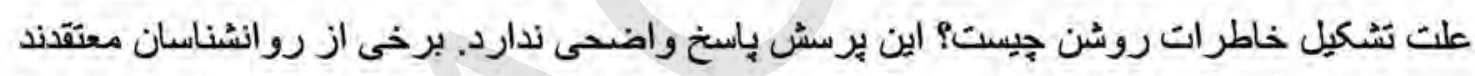

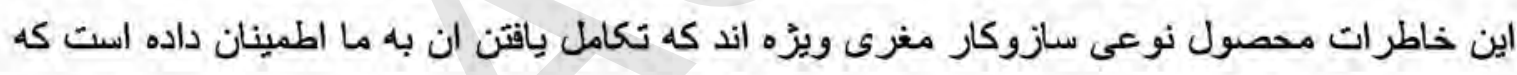

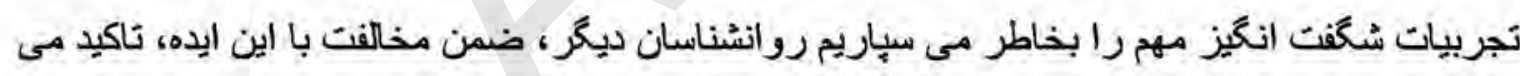

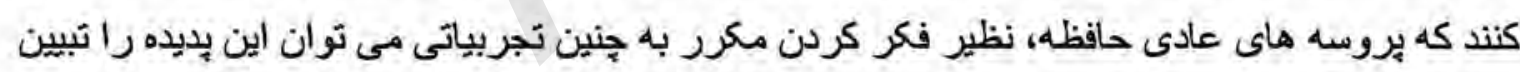

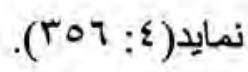

ماهيت دقيق خاطرات روشن از طريق انجام يزوهش در زمينه حافظه يعنى بروسه ى كه اططلاعات

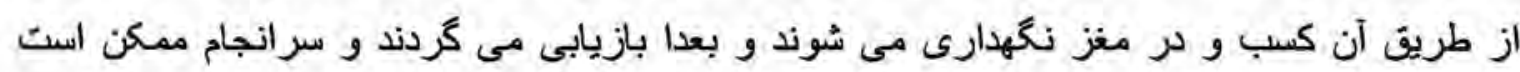

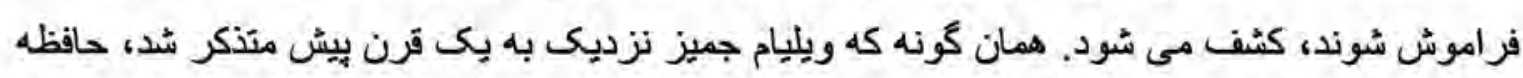

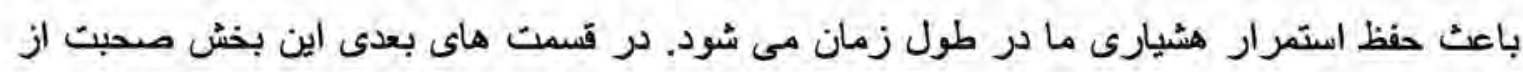

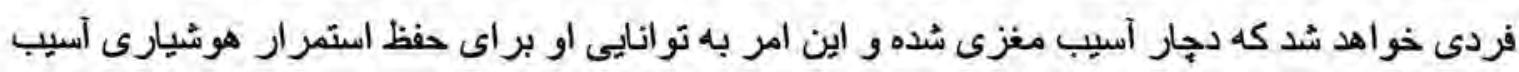

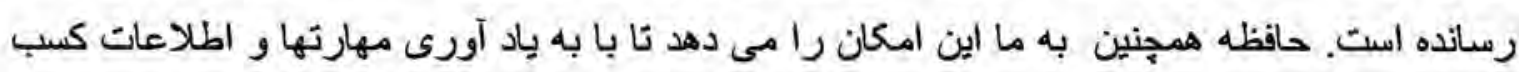

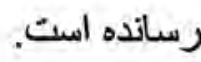


بر بررسى حافظه، روانشناسان جندين سوال اساسى را مورد ثوجه قرار مى دهند، خاطرات

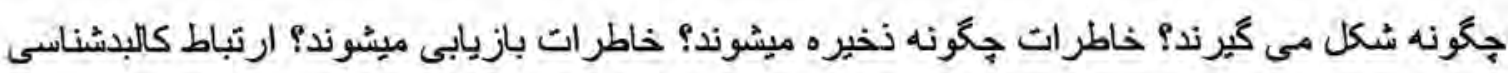

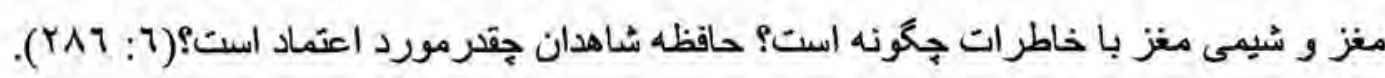

\section{جمع آورى اطللاعات حافظه}

درسه دهه كذشته ،يُرو هش هاى حافظه تحت تاثير (انقلاب شُناختى ) در روانشناسى قرار داشته

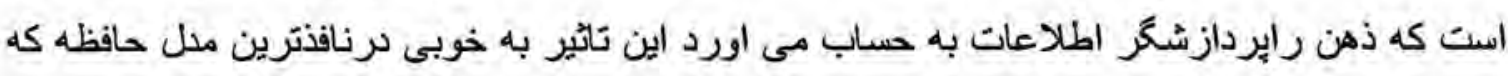

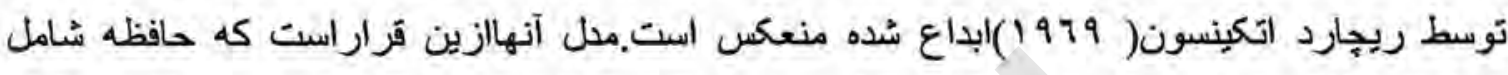

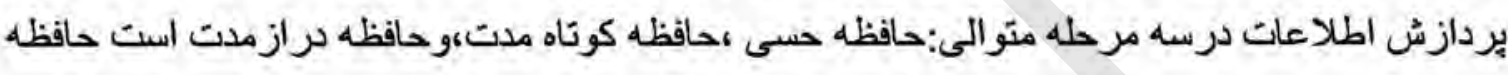

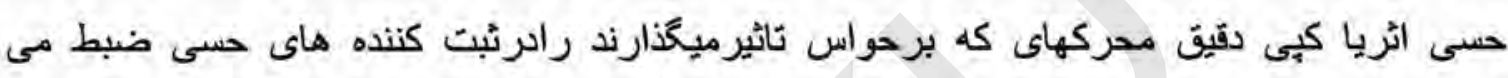

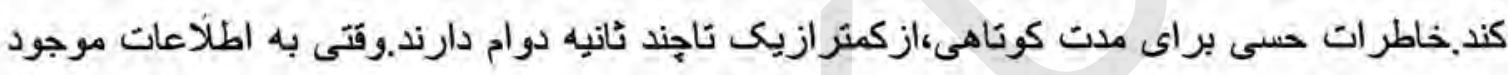

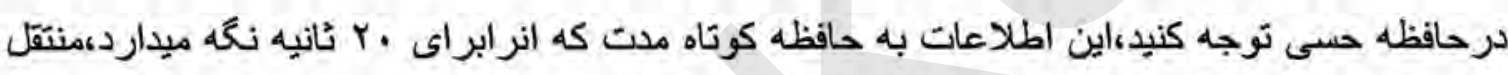

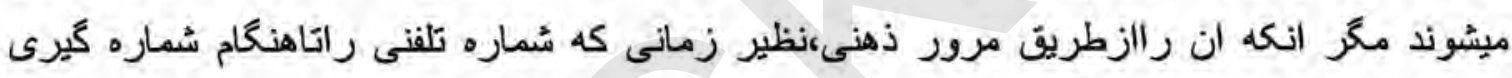

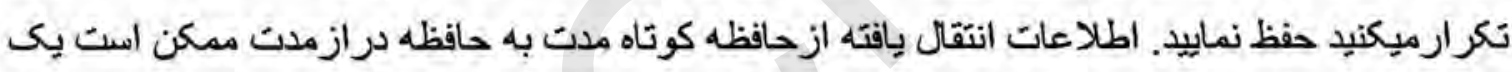

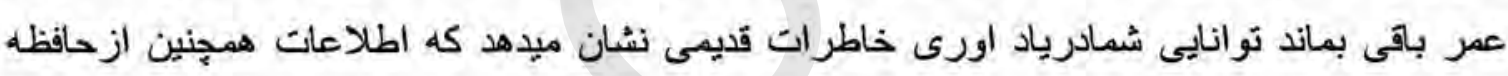

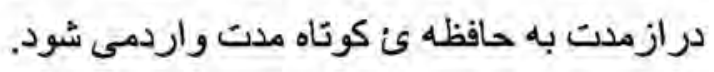

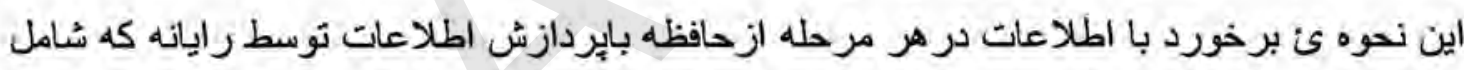

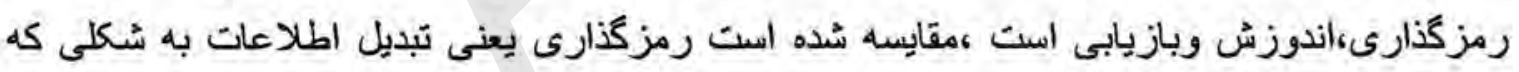

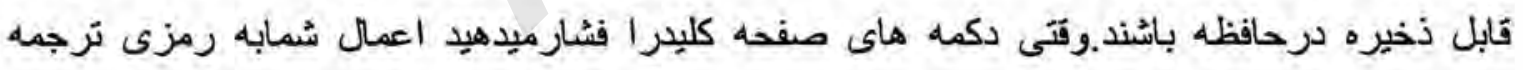

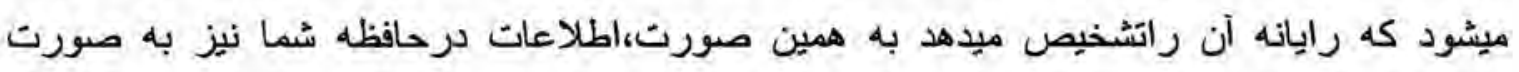

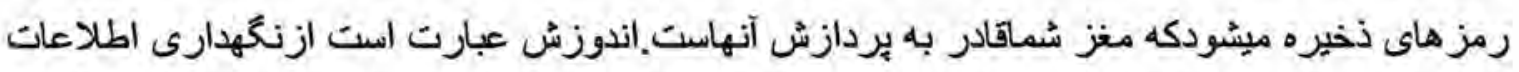

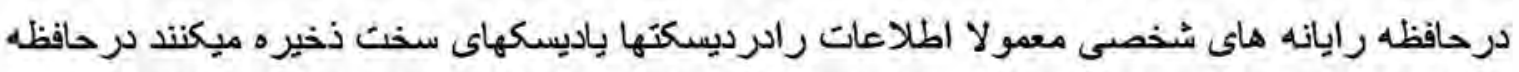

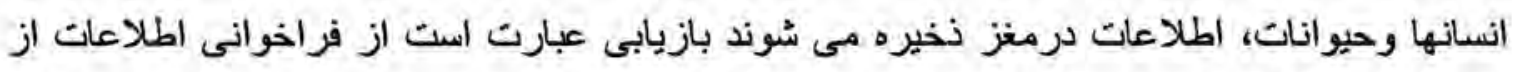

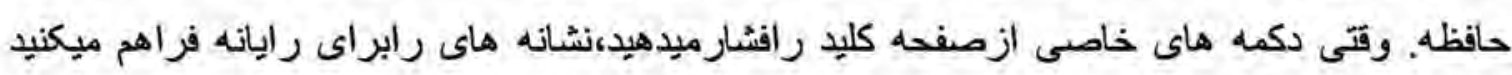

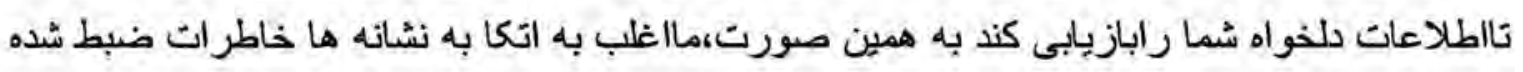

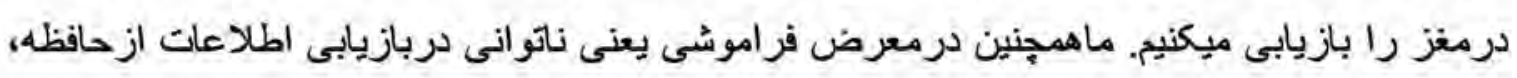
قرار داريم. 
اين مدل يردازش اطلاعات حافظه را به طورخلاصه نمايش ميدهد .اكرجه برخى روانشناسان نسبت به وجود مراحل مجزاى بردازش اطلاعات براى حافظه حسى ،حافظه كوتاه مدت وحافظه درازمدت ترديد

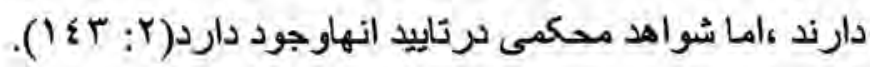

\section{انواع حافظه}

آيا تا كنون از خودتان برسيده ايد كه داراى جه حافظه ايى هستيد؟

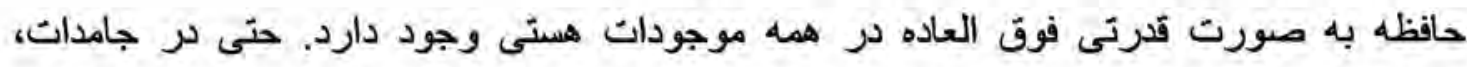

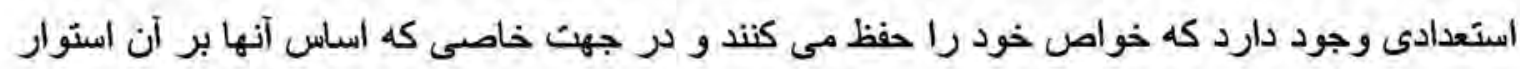

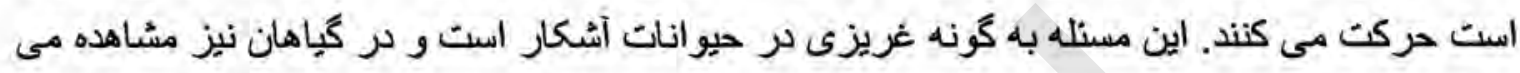
شود. قوى ترين حافظه در اتسان نهفته است ولى رر همه افراد يكسان نيست حدود 99در صد مردم از

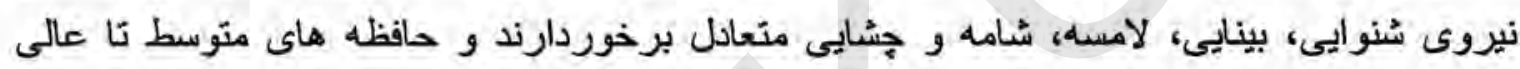

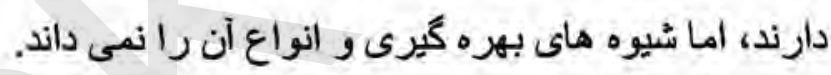

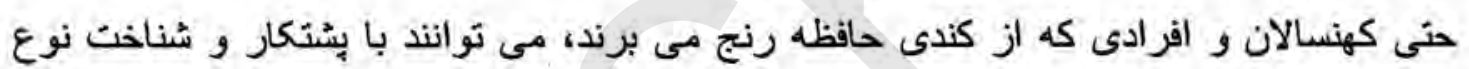

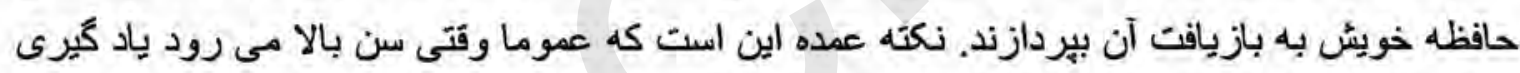

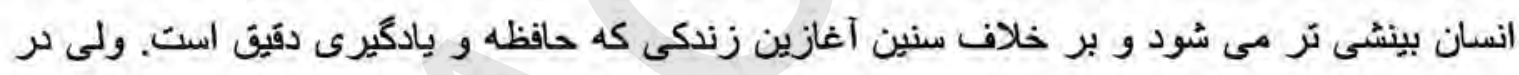

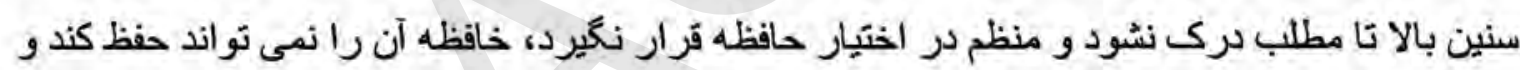

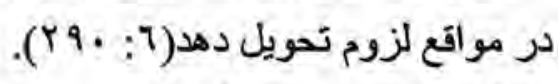

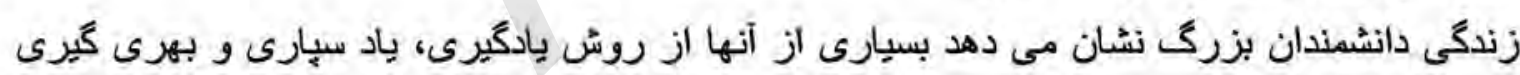

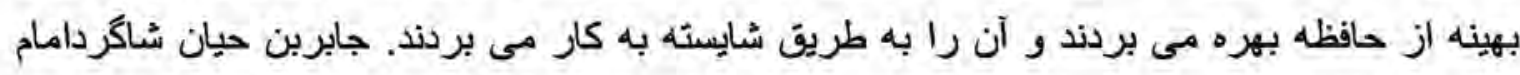

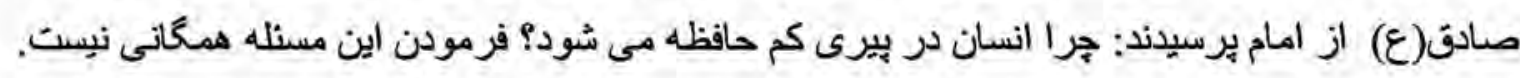

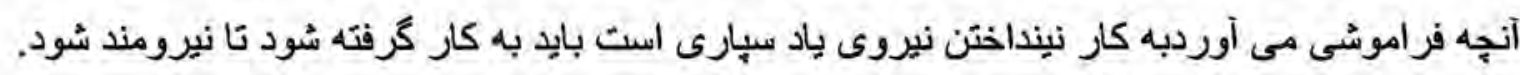

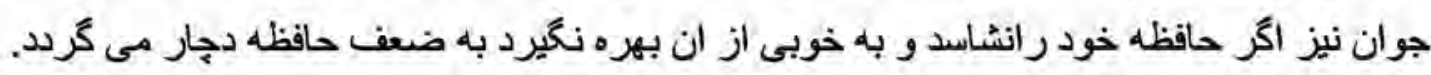

\section{حافظه حسى}

به اخرين فيلمى كه تماشا كرده ايد فكركنيد.اين فيلم عملا ازمجمو عه اي تك تصوير تشكيل شده

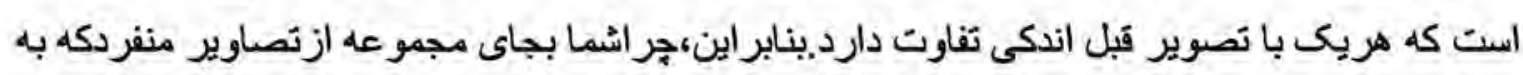

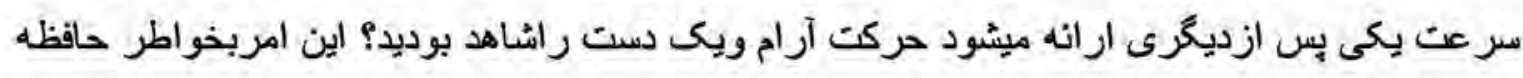
حسى ديدارى شماست كه تصاوير راتايكى ثانيه ذخيره ميكثد.حافظه حسى ديدارى حافظه شمايلى ناميده 
ميشود كه هرتصوير ذخيره شُه دران بك شمايليل يآيكون (ازكلمه يونانى به معناى تصوير كرفته شده

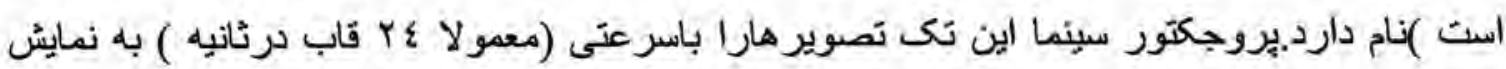

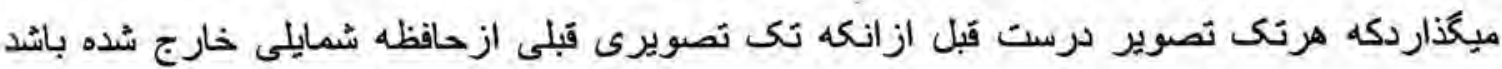

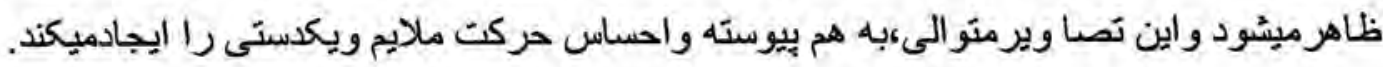

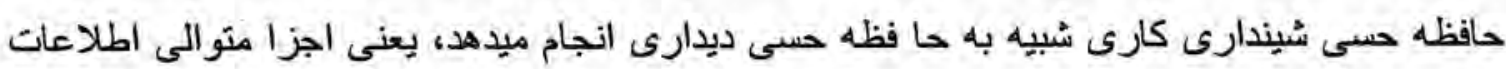

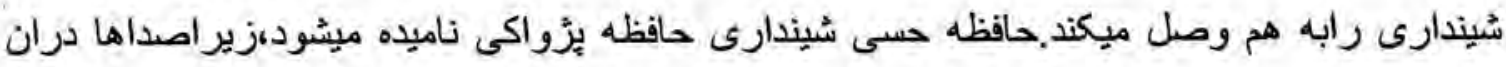
منعكس ميشود. حافظه بزّواكى اطلاعات راتابراى مدت طولانى تر ازحافظه شمايلى،يعنى معمولا

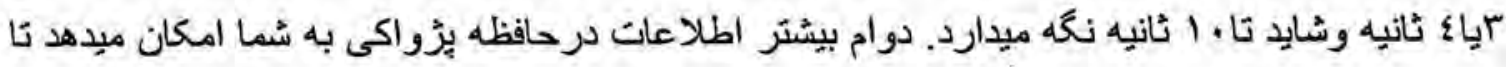

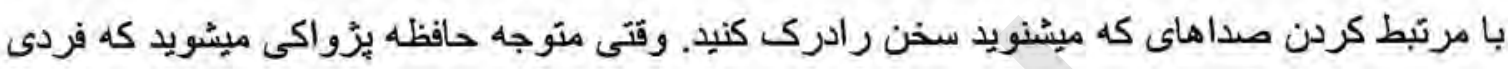

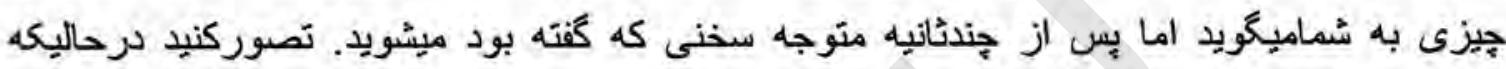

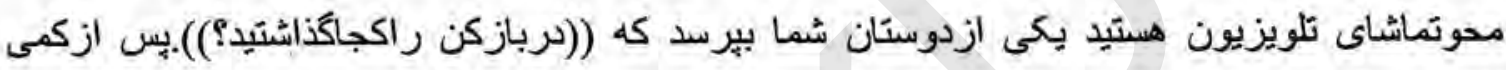

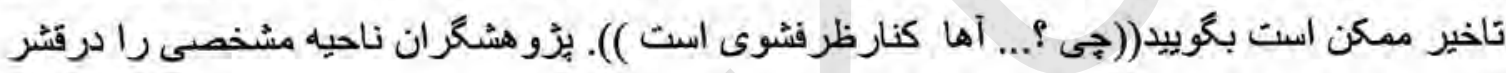
شنواى اوليه ئ مغزشناسايى كرده اند كه خاطر ات بُزو اكى رابردازش ميكند.

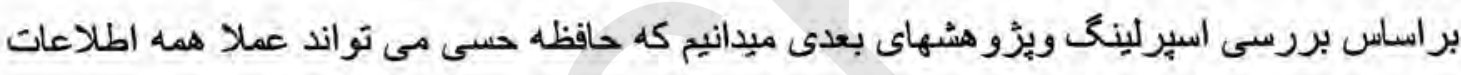

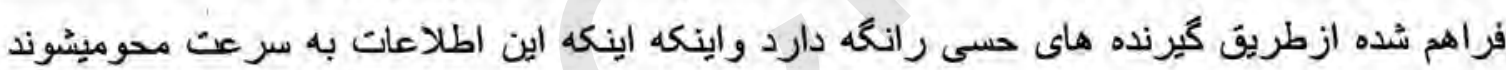

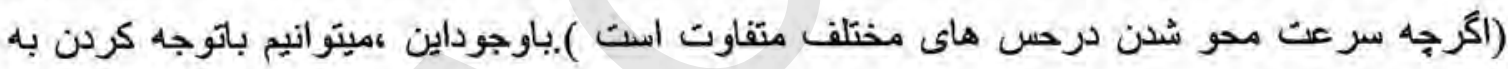

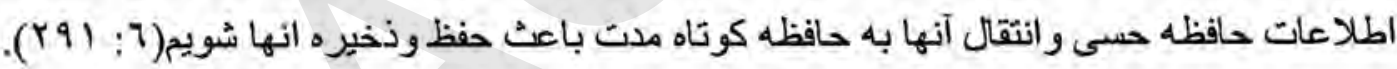

\section{حافظه كوتاه مدت (S.T.M)}

مهمترين ويزگى اين نوع حافظه ، كنجايش محدود آن است كه بطور متوسط بين هفت ماده به اضافه

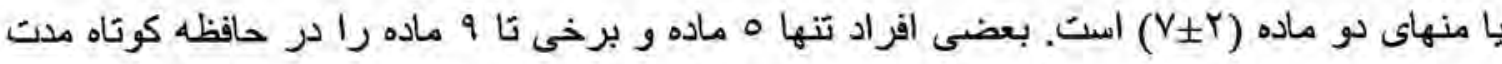

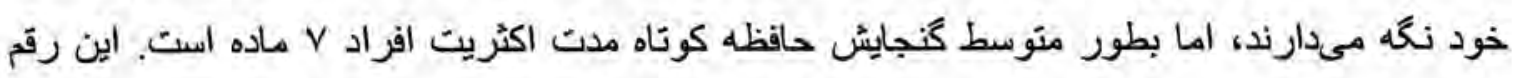
فر اخناى حافظه ناميده مى مُود (9): 10).

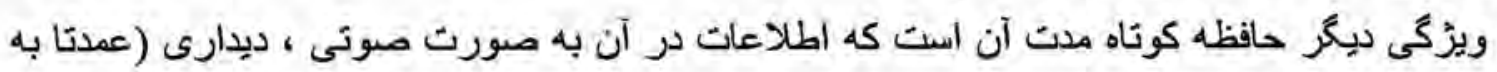

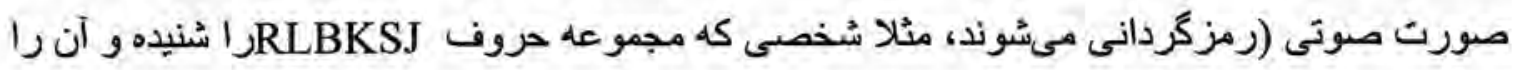

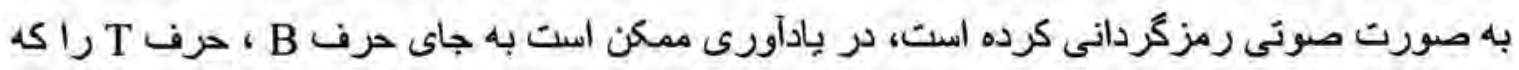
صداى مشابهى با حرف B دارد، بيان كند. بازيابى در اين حافظه كم و بيش عارى از خطاست، بطورى كه اكر مطلبى در حافظه باشد، حتما قابل دسترسى است . 


\section{حافظه دراز مدت (L.T.M)}

مهمترين ويزگَى اين نوع حافظه كنجايش نامحدود آن است، بطورى كه مطالب زيادى را در آن ميتوان نكهارى كرد، بدون آنكه از بين بروند. به عبارنى اطلاعات در اين نوع حافظه از بين الين

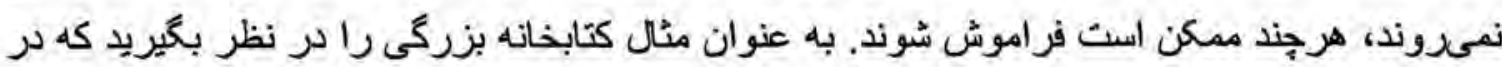

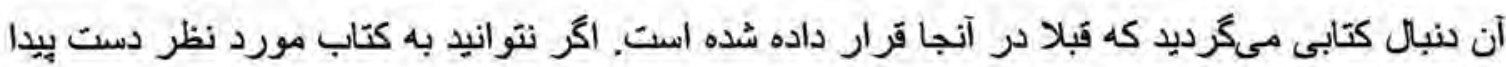

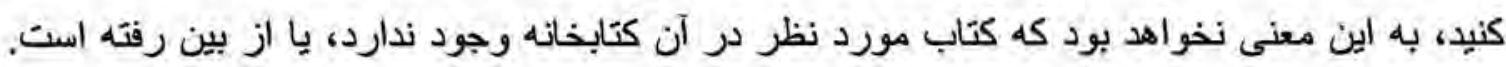

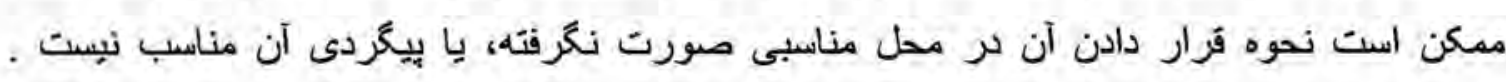

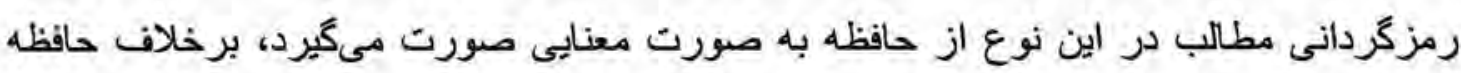

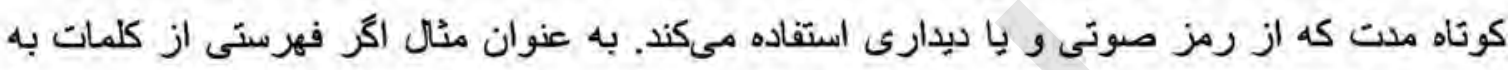

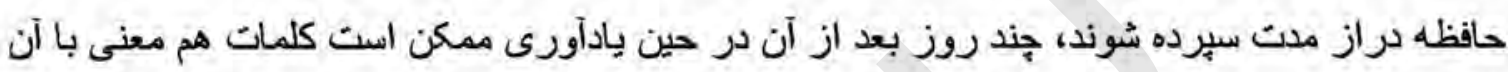

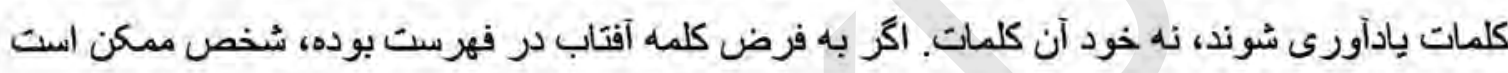

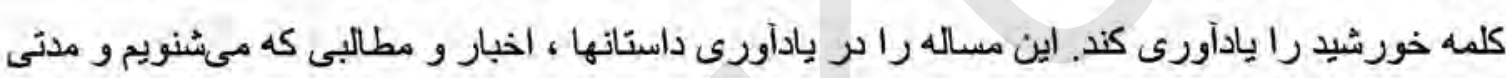

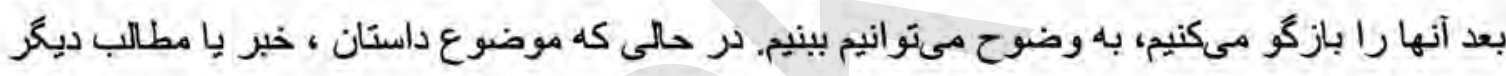

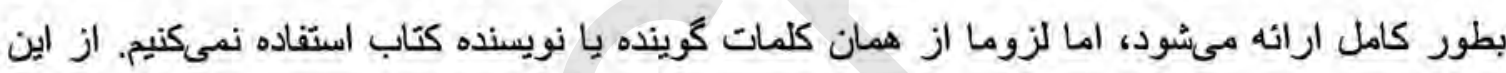

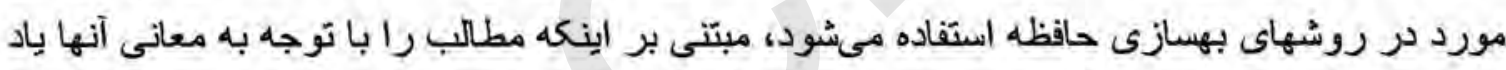
سبارى كنيم. بازيابى در اين نوع حافظه برخلاف حافظه كوتاه مدت با خطا و اشكالاتى همر اه است كه كنجايش زياد

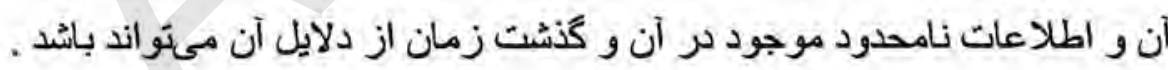

حافظه كوتاه مدت اجازه مىدهد تا براى مدت جند ثانيه تا حداكثر يكى دقيقه و اساسا بدون تمرين،

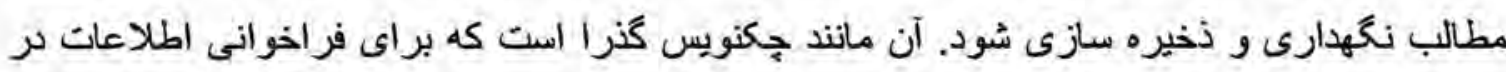

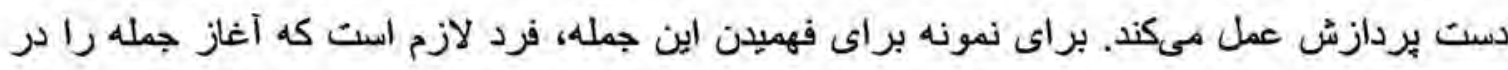

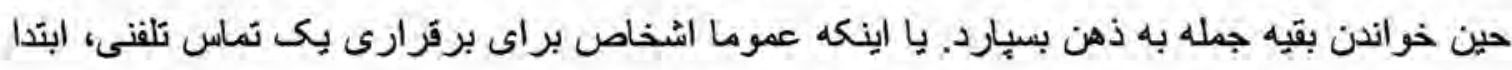

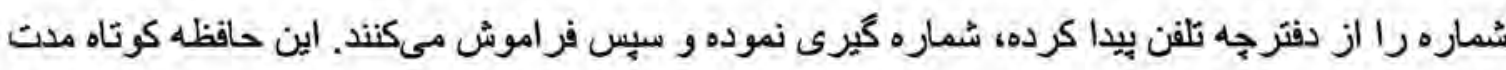

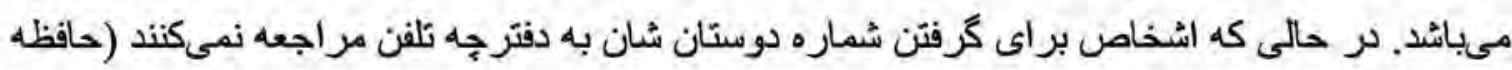

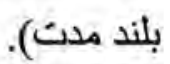

وقتى بكى مطلب بلافاصله بعد از شنيدن آن به ياد آورده مىشود، بازيابى كار ساده ترى است, جرا

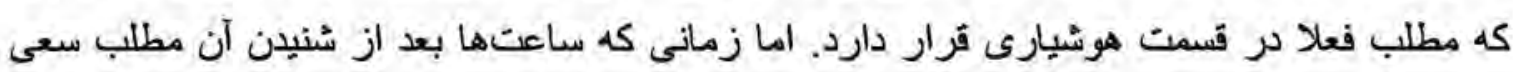

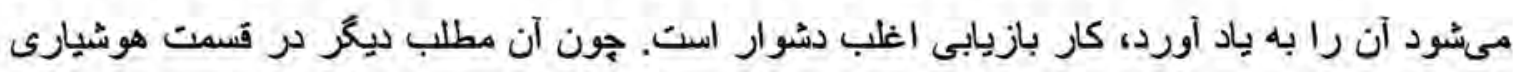

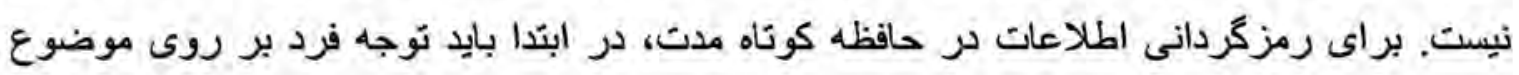


مشخصى متمركز شود (مورد توجه قرار كرفتن موضو عات). بعد از اينكه اطلاعات بخصوصى مورد

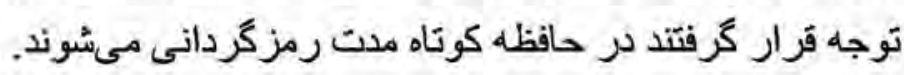

در حافظه كوتاه مدت، اطلاعات معمو لا به شكل صوتى رمزكردانى ميشوند. هرجند ممكن است از

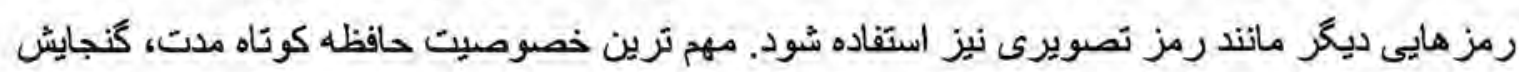

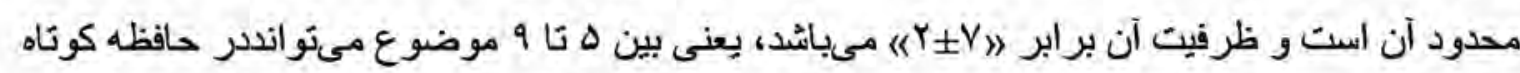

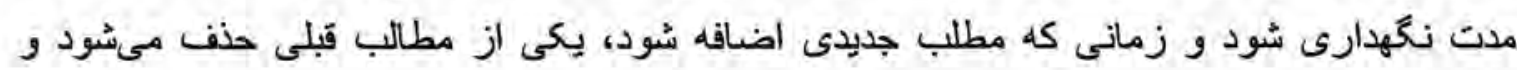

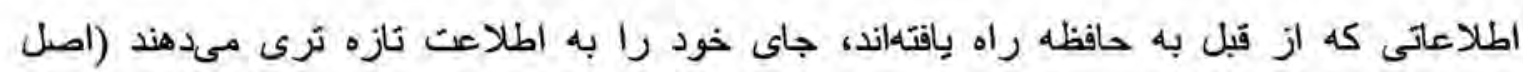

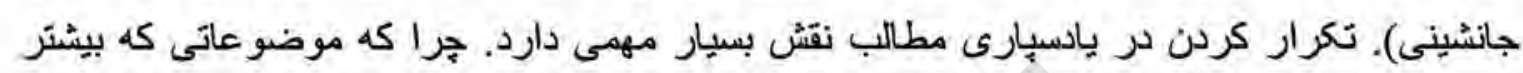

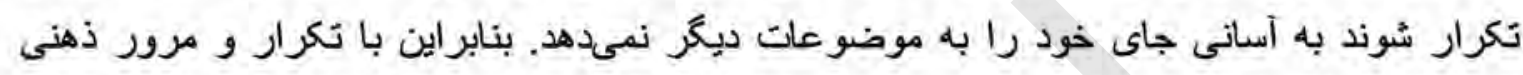

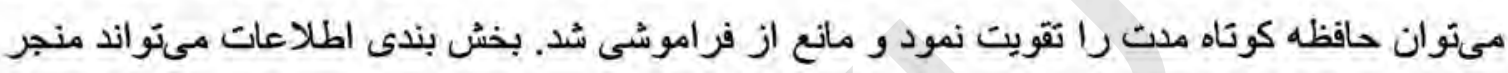

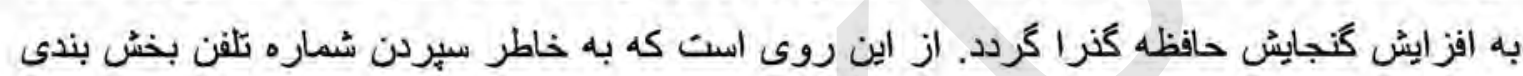

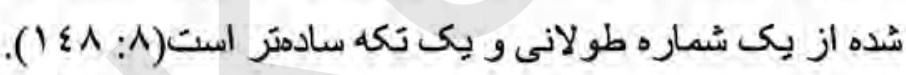

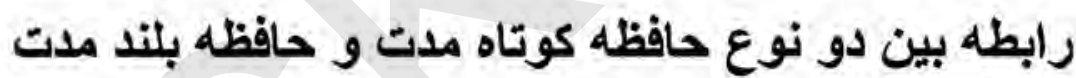

آيا بين حافظه كوتاه مدت و حافظه بلند مدت رابطهاى وجود دارد؟ اين دو نوع حافظه از جها راهى

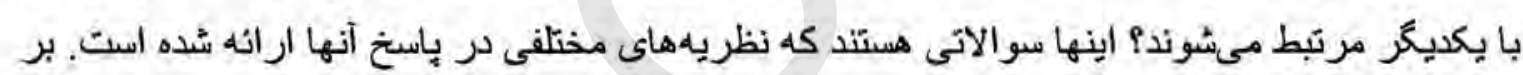

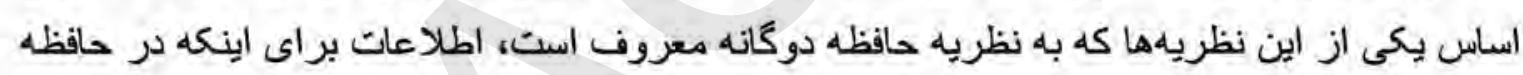

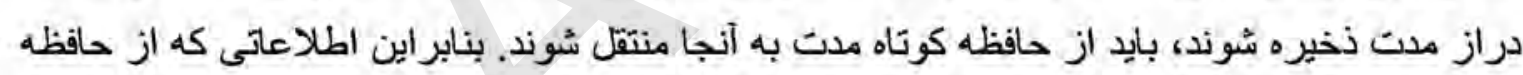

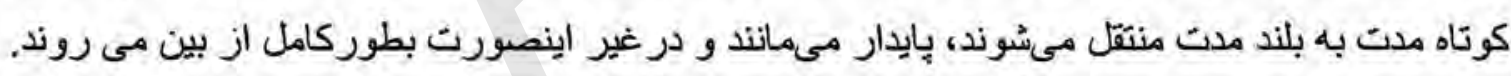

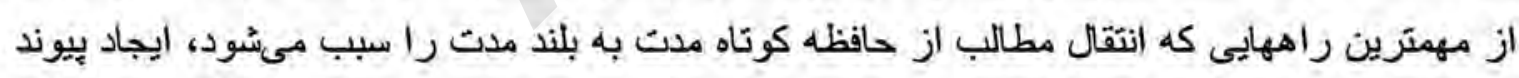

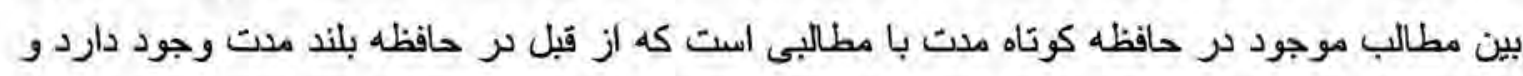

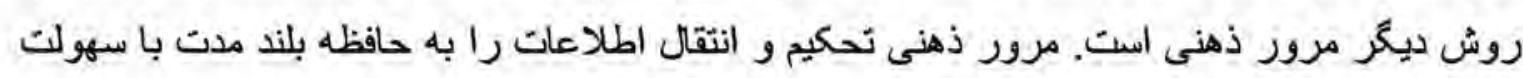
انجام مىدهد. . روثي ديكر

ذخيره سازى در حافظه كوتاه مدت به طور كلى از نظر ظرفيت و مدت زمان به شُدت محدود

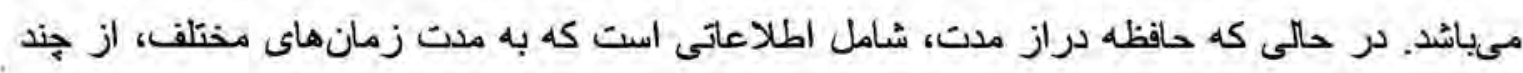

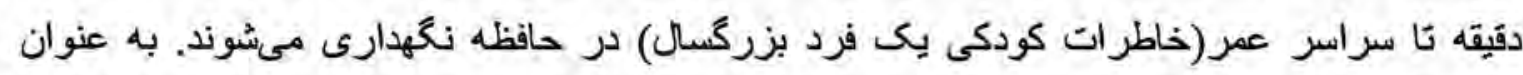

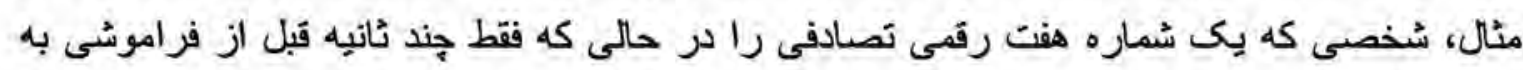

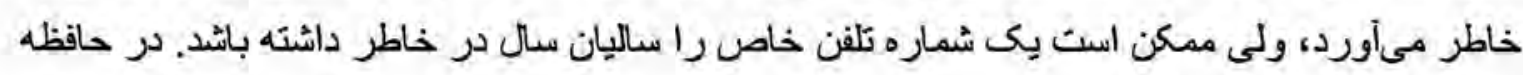

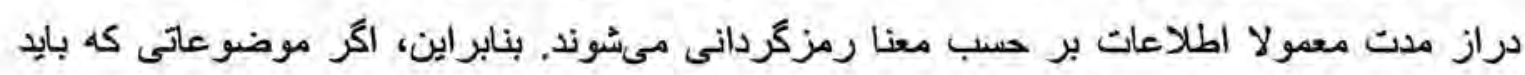


يادآورى شوند، معنادار باشند، بهرَ بادآورى مىگردند. وقتى معناى مطلبى فهميده نشود، بسيار سريع

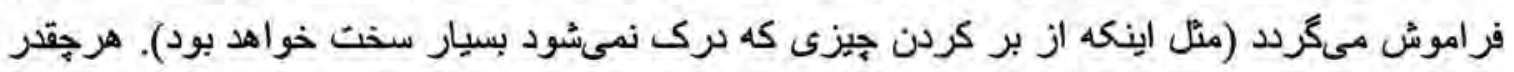

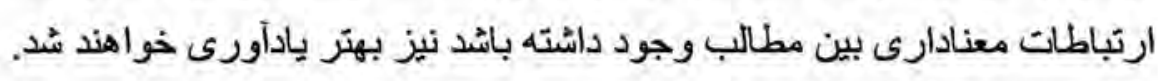
طبقه بندى حافظه بر اساس نوع اطلاعات در حافظه بلند مدت

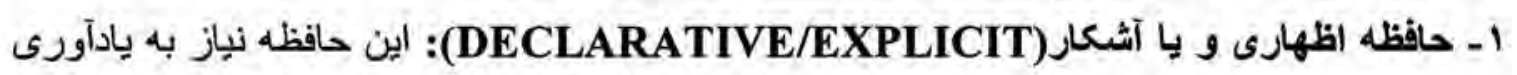
آكاهانه و هشيارانه دارد. بروسه يادكيرى در حافظه آشكار خودآكاه است. براي بازيابى آن به محركات مختصر و سرنخ ها نياز است. به دو زير مجمو عه تقسيم بندى ميكردي:

حافظه معنايى(SEMANTIC MEMORY): دانش عمومى ما از جهان بيرامون را در

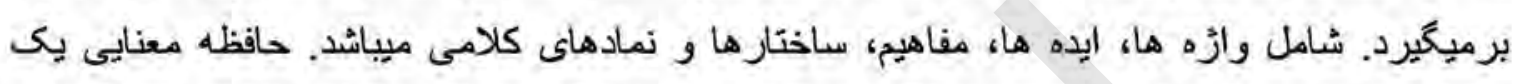

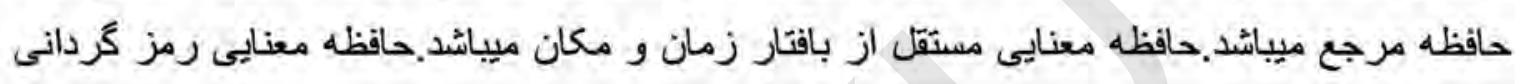
أنتز اعى دانش است. مرجع.

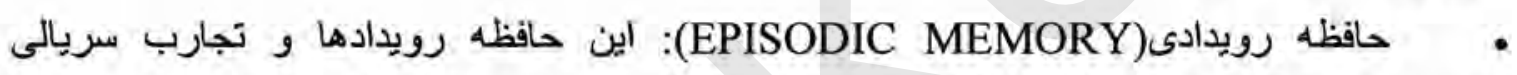
(زنجيره اى) را در برميكيرد. اين حافظه به بافتار زمان و مكان وابسته است. حافظه رويدادى همان

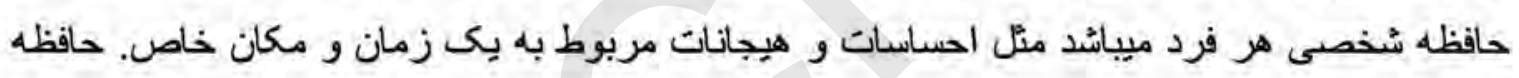

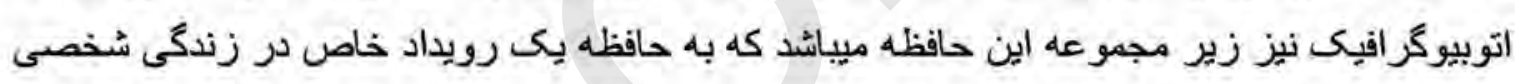

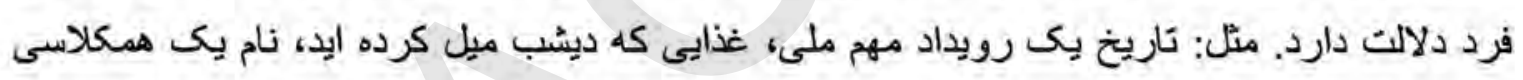

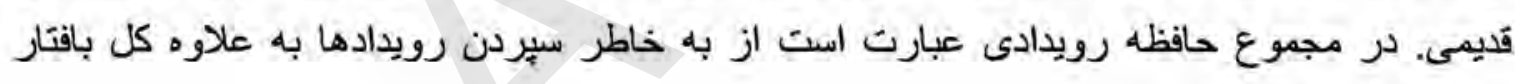

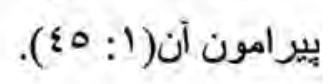

r ب حافظه روندى و يا ضمنى(PROCEDURAL/IMPLICIT): اين حافظه به يادآورى خودآكاه

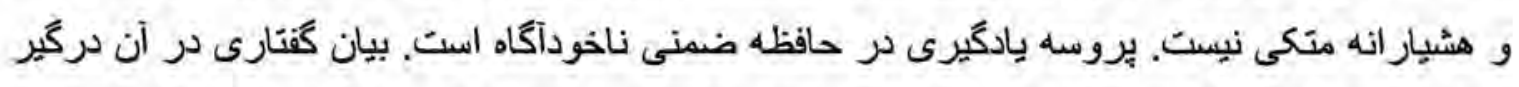

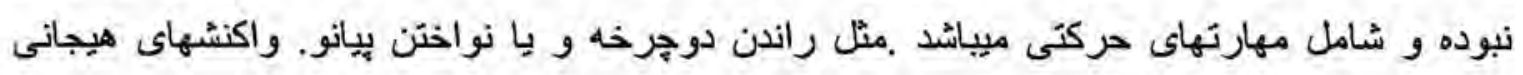
شرطى شده نيز در اين دسته جاي دارند.

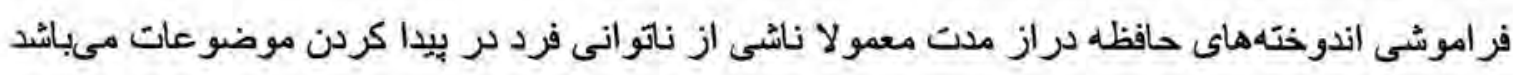

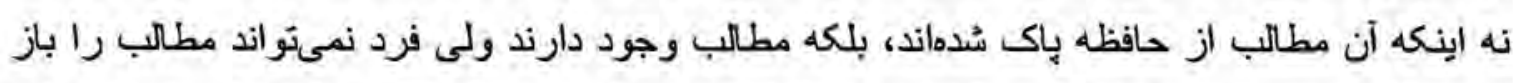

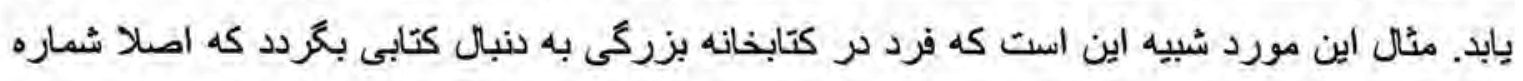

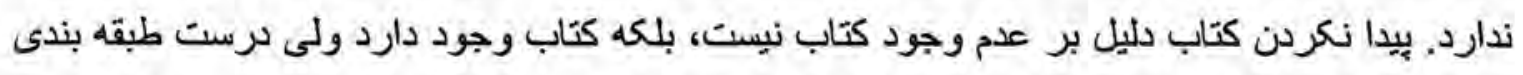

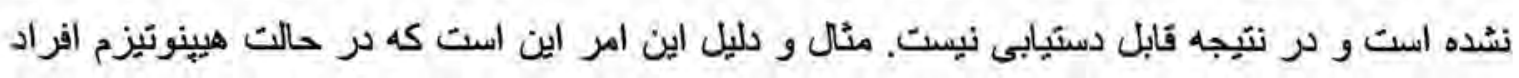

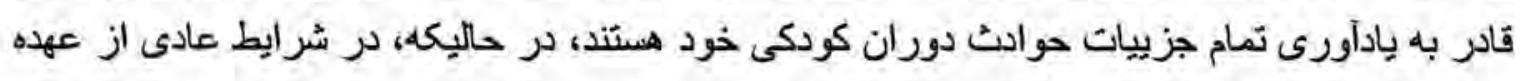
يادآورى اين خاطرات برنمى آيند. 


\section{تقسيم بندى كلى حافظه}

در نشاه نخست حافظه سه نوع است: كوتاه مدت، ميان مدت و بلند مدت. مطالبى كه به حافظه كوتاه

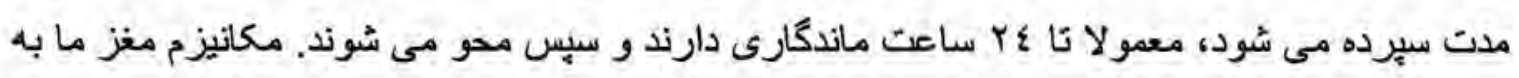

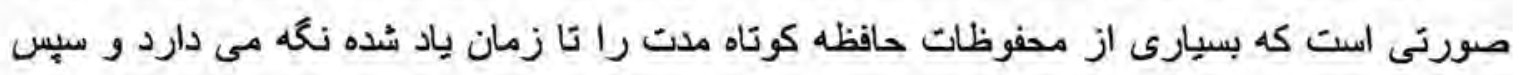

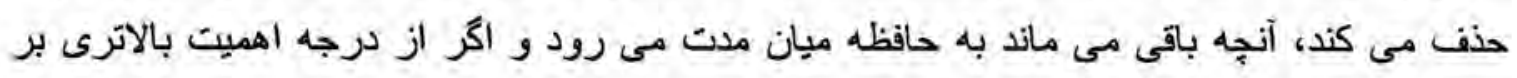

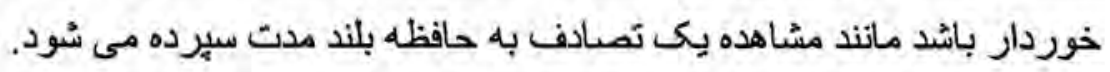

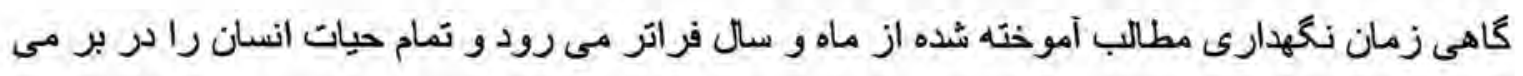

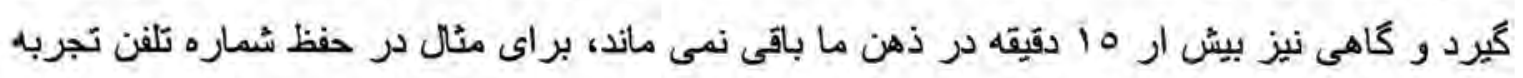

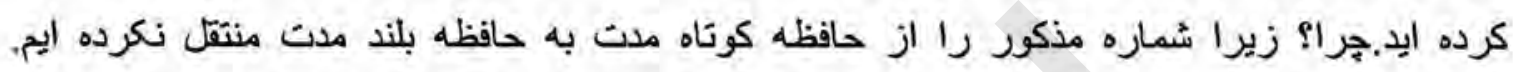

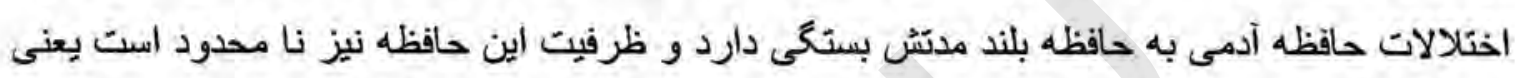

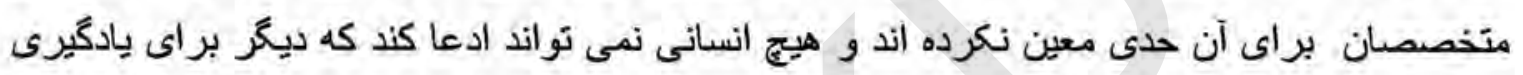
مطالب جديد جا ندارد. همه ما از حافظه مناسب بر خورداريم. مهم ترين مشكل برنامه ريزى حافظه، اعتماد به حافظه و

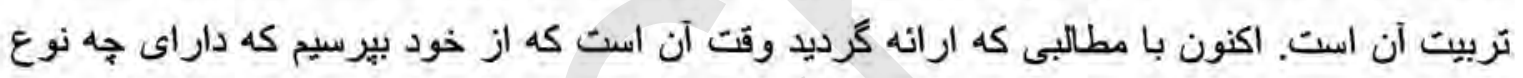

حافظه ایى هنتيّج

\section{تقسيم بندى فردى حافظها}

به طور كلى افراد در يادكيرى، مطالعه و نحاه داشتن مطالب به ع دسته كه در حقيقت نماينده جهار نوع حافظة اند تقسيم مى شوند: 1 - (- - مافظه شنيدارى(سمعى)

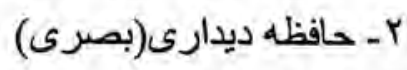

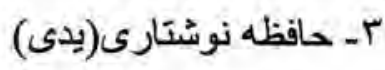
ع- حافظه حسابكر انه(آمارى)

بسيارى از مردم هنوز اين جهار حافظه را نمى شناسند و حتى نمى دانند كدام يك از آنها در وجود شان قوى تر است. 


\section{حافظه شنيدارى}

افرادى كه از راه شيندن و تمركز شنيدارى به مرحله يادكيرى بإيدار مى رسند، داراى حافظه

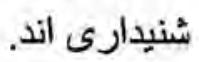

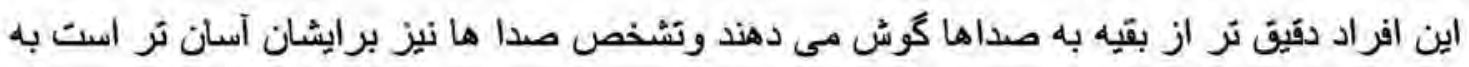

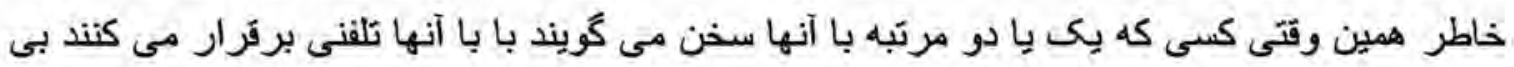

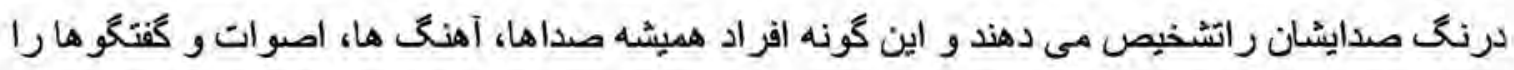

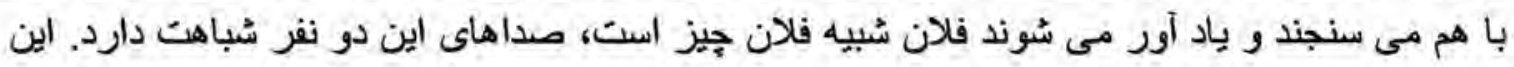

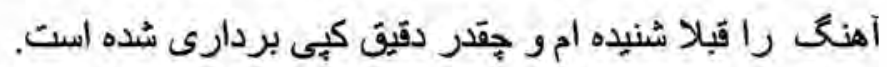

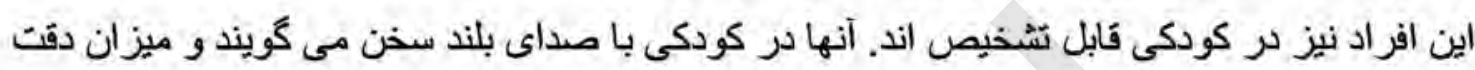

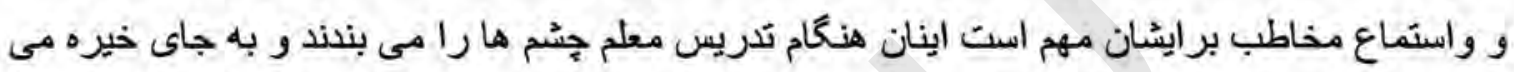

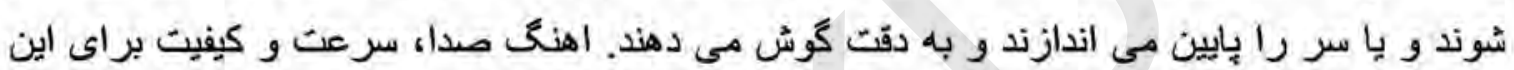

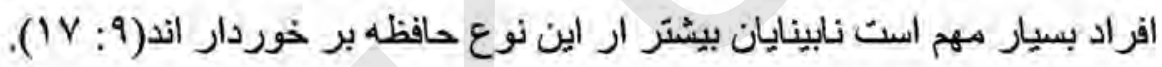

\section{نشانه هاى رفتارى}

افرادى كه در يادكيرى بيش تر از حافظه شنيدارى أستفاده مى كند از نشانه رفتارى زير بهره مى برند:

$$
\text { - ميشتر به وارٔه سمعى تكيه دارند. }
$$

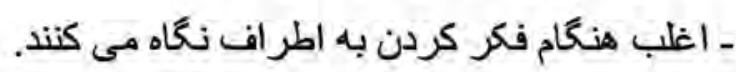

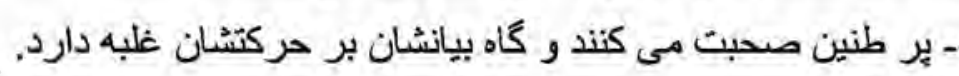

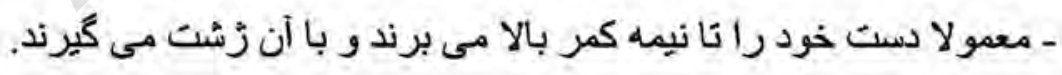
ـ عموما بيُشر از ديكران مى برسند.

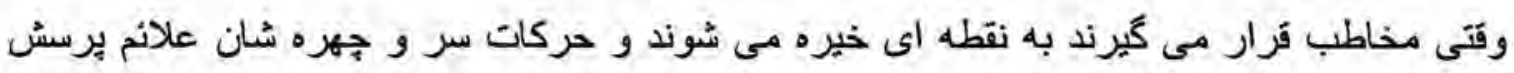
بذيرش تاييد و تعجب را تداعى مى كند.

\section{استفاده بهتز از حافظه شنيدارى}

از آنجا كه بلند خواندن و كوش دان به مطالب به يادكيرى آنها منجر مى شود، بهتر است به جاى

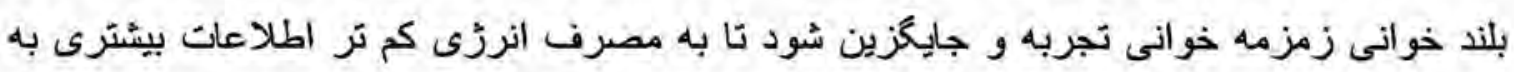

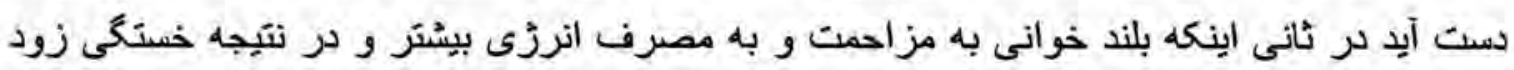

$$
\text { هنكام منجر مى شود. }
$$

ـ محيط خلوت دورى از سر صدا هائ مز احم ونور كافى بسيار مهم است. 
- بهتر است براى استماع بهتر و رساتر در حد امكان به استاد نزديك تر نشيت. - از آنجا كه اطلاعات به صورت فله اي وارد مغز مى شود براى اينكه دسته بندى و طبقه بئدى شوند و به يادكبرى بايدارثر منجر شود و به آنجه ديده مى شود به صورت برسش برخورد كردد.

- ضبط درس و استماع مجدد آن مفيد است. بازكو كردن درس با مطلب مهم آن ثوسط خود فرد با ضبط كردنش و گوش كردن و گوش كردن مجدد

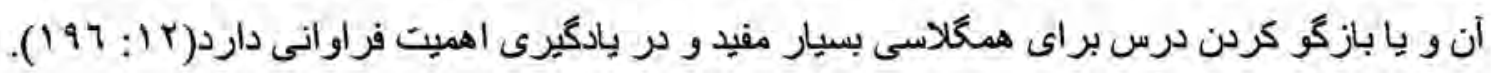

\section{حافظه ديدارى (بصرى)}

افرادى كه از راه ديدن و تمركز روى صحفه و تصوير بردارى از مطلب بهتز مى آموزند، نكه مى دارند، يادآورى مى كنند و مطالب را دوباره به صحفه فعال ذهن خود مى آورد از اين حافظه بر خوردارند. امروزه عقيده برآن است كه . . درصد آموخته ها و تجارت از راه جشم به دست مى آيد. اين دسته از افراد جهان را به وسيله تصاوير ادراك مى كنند و حتى آرس ها را بر مبناى نشانه ها ى فيزيكى مى اورند براى مثال : به يِار نشانه ها، تابلو ها، مغازه ها و ادرات مكان خاصى را به بِاد مى سبارد.

اين افراد در كودكى نيز قابل تشخيص اند بعنى وقتى تازه زبان مى گثايند هنگام كنتخو با بزرى ترها به جشمان آنها مى نكرند. اين حافظه به راحتى قابل توسعه است. مى توان بيشتر مطالب درسى را به يارى تصوير به ياد سيرد و هر صحفه را به صورت تصويرى در حافظه نـأهارى كرد. بار ها اتفاق افتاده است كه هنگام بيرون آمدن از جلسه امتحان دوستانمان درباره محل باستخ سوال امتحانى از ما سوال مى كند و اكر مر جمع دوستانمان باشيم اكر ماو دوست ديخر جواب سوال را ندهيم دوست ديكر كه از اين قوه برخوردار است جواب ما را مى دهد و براى مثٔل مى كويد كه جواب در صحفه هشتاد بود. بعضى از افر ادى آنكه بدانتد ار اين حافظه سود فراوان مى برند و فكر خود را خسته نمى كنند. استفاده بهنر از حافطه ديدارى: ا ـ تمركز نگاه بر جملات و جار اكرافها و سبس بستن جشم ه و انعكاس مطالب عمده به ذهن و نشاه مجدد به آن.

r تلفيق مطالب با تصوير ها، شكلها، نمودار ها r- علامت كذارى معنا دار، از خط كشى ساده زير كلمات تا علانم ابتكارى. ع- مطالعه و سبس تلاش در احضار صحفه و هباراكراف مطالعه شده بعد از هر بانزده دقيقه. 
در آموزش اين افراد مى توان از كتابهاى نمودارى وتصوير و جدول و نيز وينو و هجنين فيلم هاى

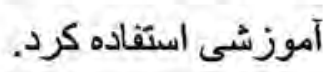

\section{حافظه نوشتارى(يدى)}

افرادى كه از راه نشتن و لمس و دسته بندى منطبق بر ذوق خود بهئز ياد مى گيرند.از حافظه نوشَّارى

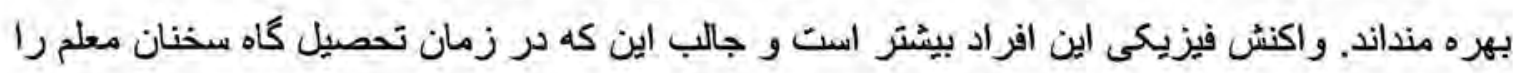

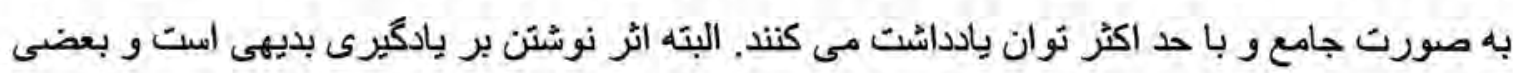

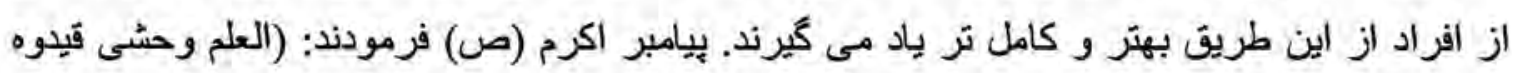

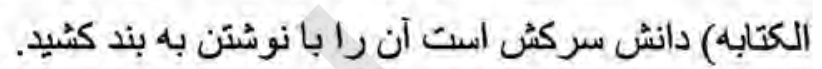

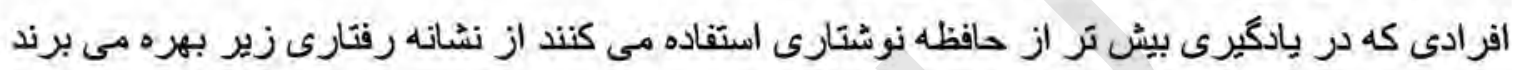

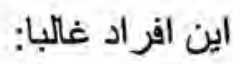
1 - هنكام فكر كردن به سمت بايين و راست خود نكاه مى كند.

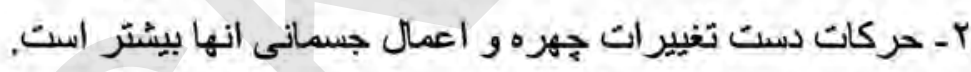

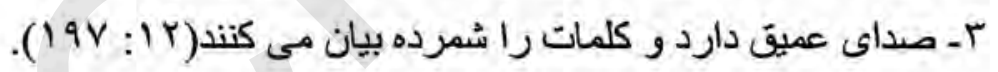




\section{روشهاى تقويت حافظه}

در اين زمينه، دو تا از مهرترين كار هايى كه ميتو انيد بكثيد، يكى اجتناب از حفظ كردن و با عجله

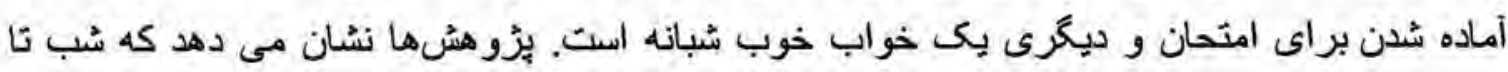

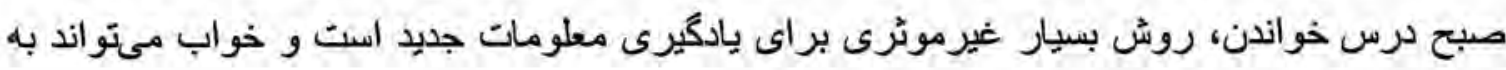
استحكام حافظه و عملكرد بهتر در امتحان كمك كند.

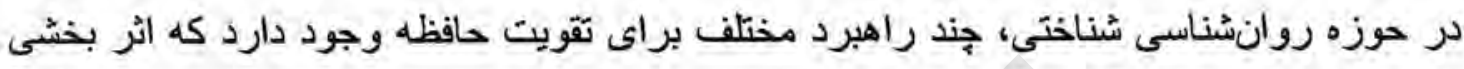

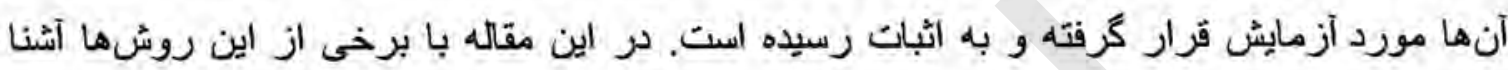

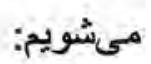
ا- توجه خود را بر روى آن جه مطالعه مىكنيد مثمركز سازيد. توجه بكى از مؤلفههاى عمده حافظه.

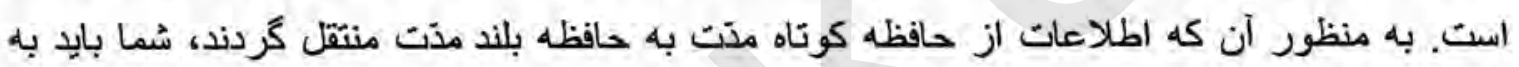

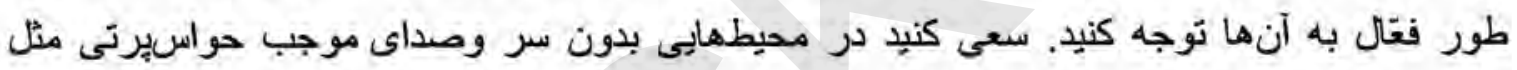
تلويزيون، موسيقى و ... مطالعه كنيد. r- از حفظ كردن مطالب و با عجله براى امتحان حاضرشُن بيرهيزيد. جلسات منظمى براى مطالعه.

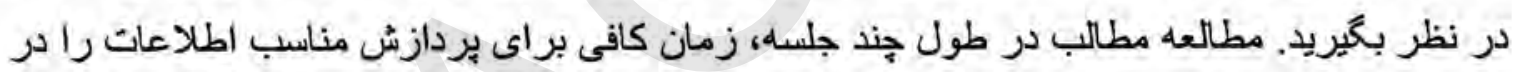

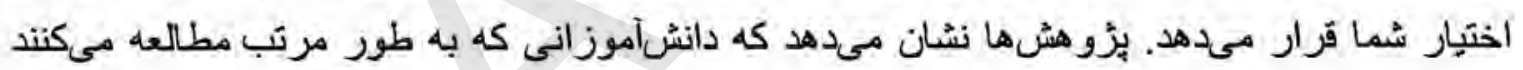

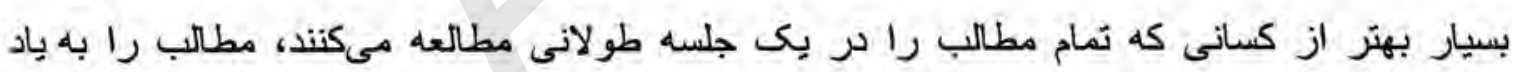
مى آورند. rـ اطلاعاتى كه مطالعه مىكنيد را سازماندهى كنيد. بزرو هشكُران دريافتهاند كه اطلاعات در حافظه به

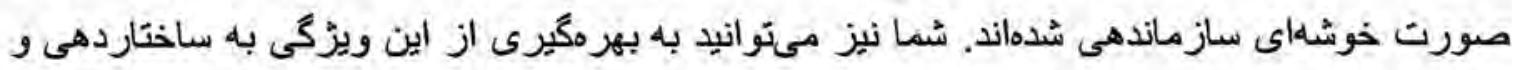

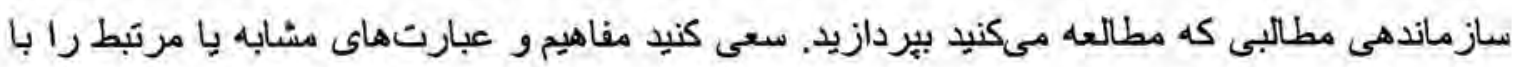
هم كرو مبندى كنيد. ع- از وسايل ياد يار براى به خاطر سبردن اطلاعات استفاده كنبد. منظور از وسايل ياديار، روشى ئي

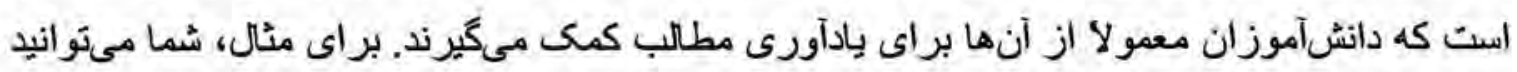
عبارتى كه بايد به ياد آوريد را به جيزى كه خيلى برايتان آشناست مرتبط سازيد.

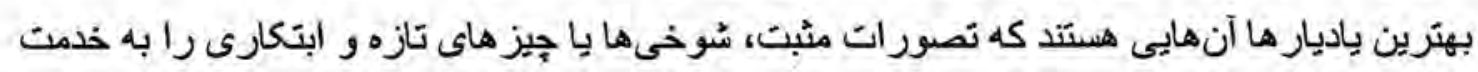

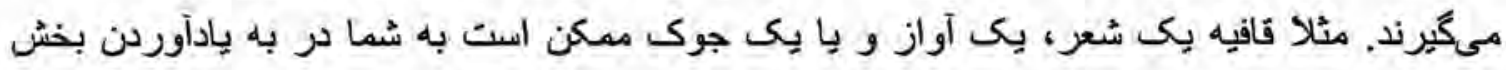
خاصى از اطلاعات كمى كنثن. 
ــ اطلاعات را در ذهنتان بسط دهيا و مرور كنيد, براى به خاطر آوردن اطلاعات، شما بايد آنجه مطالعه كردهايد را در حافظه بلند مدّت خود قرار دهيد. يكى از موثرثرين روشها، بسط و مرور نام دارد. يكى مثال از اين روش اين أست كه ابثدا تعريف عبارتهايى كليدى را بخوانيد، سبس با دقت بيشتر آن تعريفها را مطالعه كنيد و سرانجام به مطالعه تشريح جزنيات معنى آن عبارتها بِّردازيد. بس از جند بار تكرار اين بروسه، بادآورى اين اطلاعات بسيار بهتر و آساتتر خواهد شُ.

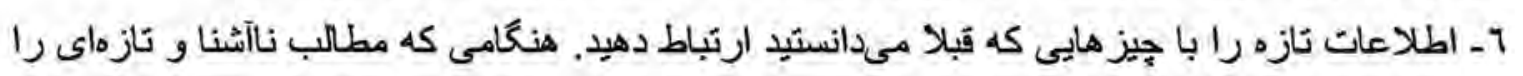
مطالعه مى كنيد، مدتى را به فكر كردن در مورد اين كه اين اطلاعات جه ارتباطى با دانستهايى قبلىى شما دارد اختصاص دهيد. با ارتباط برقرارى كردن بين ايدههاى جديد و دانستهاى موجود قبلى، احتمال بهه خاطر آوردن اطلاعات تازه به ندو جشمعيرى أفزايش خواهد بيافت. V- مفاهيم را در ذهنتان مجسنم كنيد. بسيارى از افراد با مجستم كرن اطلاعاتى كه مطالعه كردهاند، قرت حافظه و به يادآورى خود را بهيود جشمعيرى مىبخشند. به عكسها، نمودار ها و ساير نصاوير كتابهاى درسىتان توجه كنيد. حتى اكر جنين تصناويرى وجود ندارد مىتوانيد خودتان ايجاد كنيد. در

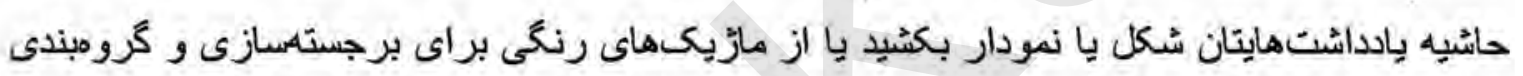
مطالب مرتبط استفاده كنيد.

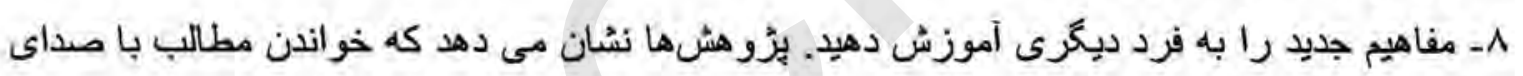
بلند، در به خاطر سبردن آنها بسيار موثر است.

روانشناسان همجنين دريافتهاند كه در صورتى كه دانش آموزان به 》تكريسه" مفاهيخ جديد به ديكران بيردازند، درك و يادآورى آنها بهيود بيدا خواهد كرد. شما مىتوانيد با آموزش دادن مفاهيم و اطلاعات جديدبه دوست يا همكلاس خود، اين رويكرد را امتحان كنيد. 9ـ به اطلاعات بيجيده توجه بيشترى كتبد, آيا تا كنون متوجه شدهايد كه به بياد آوردن اطلاعات ابتدايىى

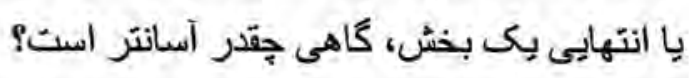

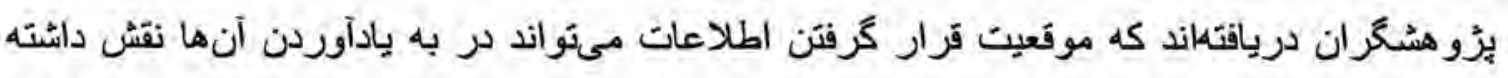
باشد. در حالى كه به ياد آوردن اطلاعات ميانى ممكن است دشوار باشد، شما مهثو انيد با صرف وقت

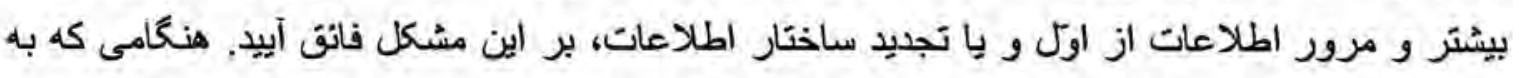
يك مفهوم بِيجيده و سخت برخورديد، زمان بيشترى را صرف به به خاطر سيارى آن كنيد. • ا- روش مطالعه خود را تغيير دهيد. يكى راه عالى براى افزايس قدرت يادآورى مطالب، تغيير كاه به

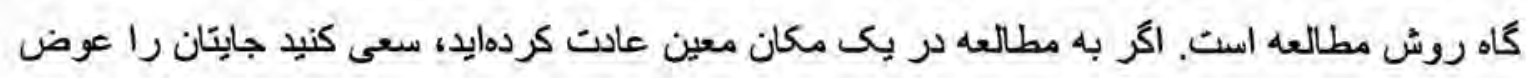
كنيد. اكر بعد از ظهرها مطالعه مىكنيد، هر روز صبح جند دقيقهاى را به مرور اطلاعاتى كه روز قبل مطالعه كردهايد اختصاص دهيد. با افزودن يكى عنصر جديد به جلسات مطالعه خود مىتو انيد اثربخشى تلاشهايتان را افز ايش دهيد و قدرت يِادآورى خود را بهبود بخشيد. 


\section{جُونه حافظه خود را تقويت كنيم؟}

روش هاى زيادى براى تقويت حافظه وجود دارد، از بين اين روش ها استفاده از فنون ذهنى خاصى

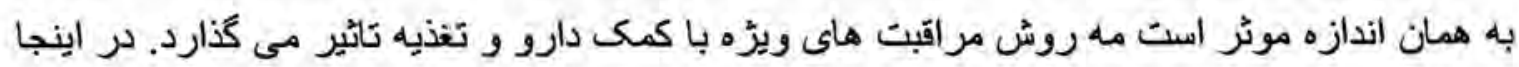
روش هايیى را ذكر مى كنيم كه فرد با انجام دادن اين روشها حافظه اس او را بهتر يارى مى كند.

\section{بر انغيختن حافظه}

از حافظه خود تا حد امكان أستفاده كنيد درباره يِى بديده نو به بحث بيردازيد. مهارت هاى تازه ياد

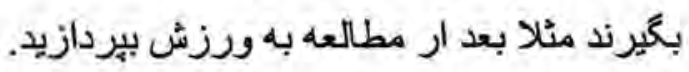

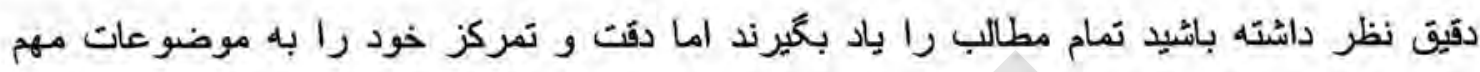

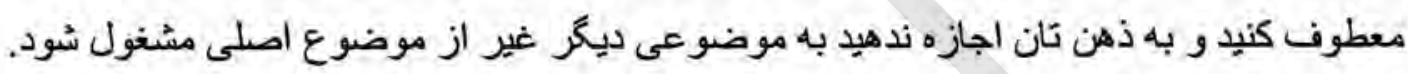

كشف راهى براى تقويت حافظه بلند مدت زيست شناسان دانشخاه هاروارد اعلام كردند تحقيقات بر روى حافظه بلند مدت بر كرم ميوه ممكن است منجر به درمانى جديد براي افرادى كه حافظه خود را از دست داده اند باشد.

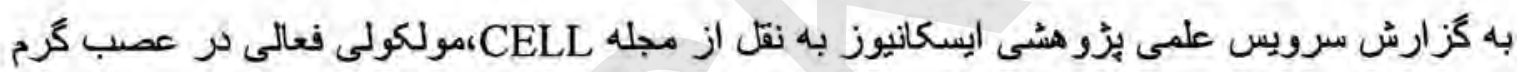

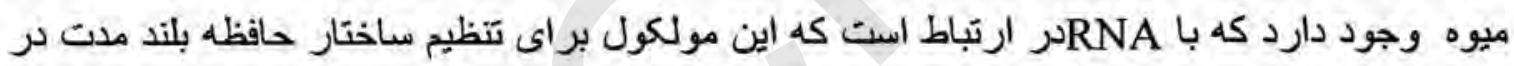
كرم استفاده مى شود.

روش فعال سازى اين ولكول مسير RISC بيوند كاه دو عصب ارتباط دارد. اين مسير به منظور مجهز ساختن بروتيني كه ساختار حافظه را شكل مى دهد است.

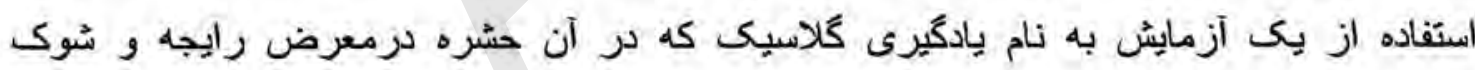

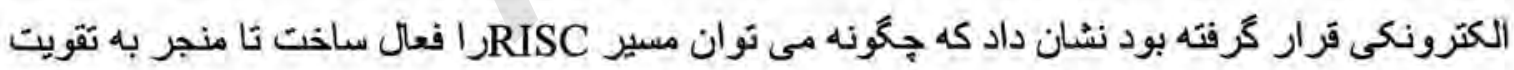
حافظه شُد. دانشمندان براين باورند كه حافظه بلند مدت به وسيله فعاليت مسير RISC در كرم ميوه افزايش مى كند

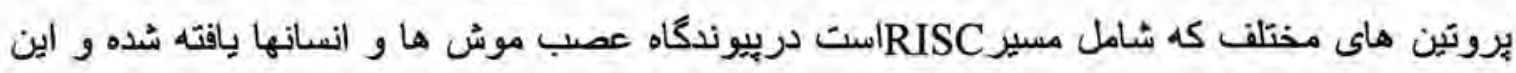

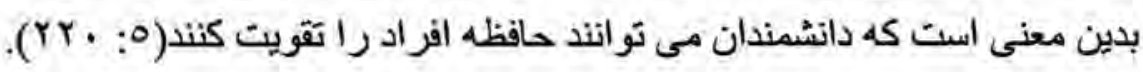

\section{بيست روش براى تقويت حافظه}

1- من حافظه ضعيفى دارم و كارى هم نمىشود كرد! اين يك جمله كاملا بى معناست, شما به سادگى

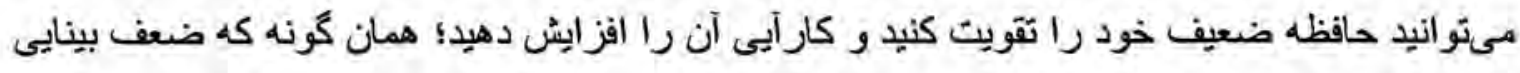

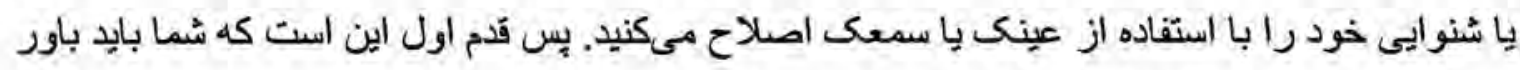


كتيد كه ضعف حافظه، بِى بيمارى كذراست و به راحتى قابلل علاج و اصلاح است. حالا وقت آن است كه دست به كار شويد(· (1: ror) Y- شما حافظهاى بسيار نيرومند داريد! باور نمىكنبد؟ آيا مىخواهيد اين امر را به خودتان ثابت كنيد؟

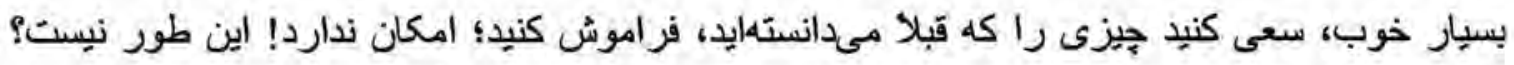

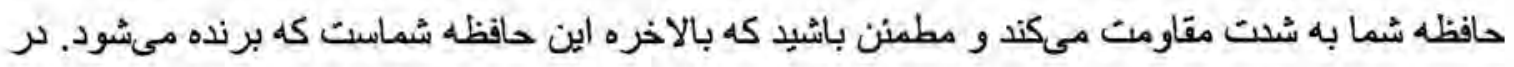

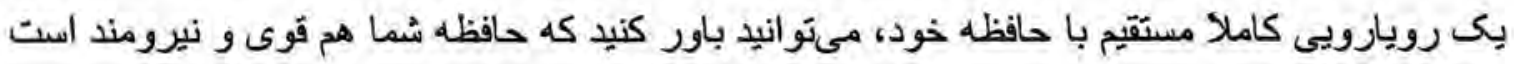

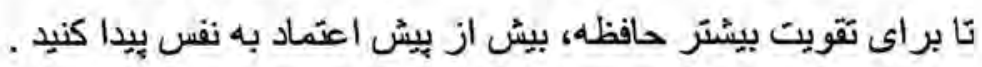

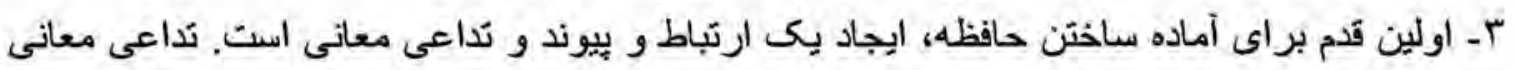

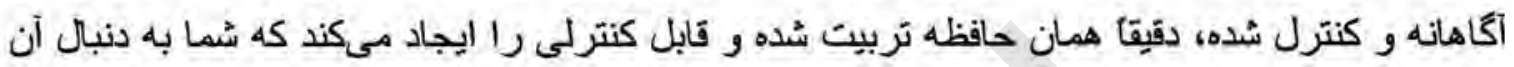
. اين بيوند يا اتصلال معانى، ممكن است أكاهانه و در اختبار يا نيمه هشيارانه و نيمه آكاهانه باتشد.

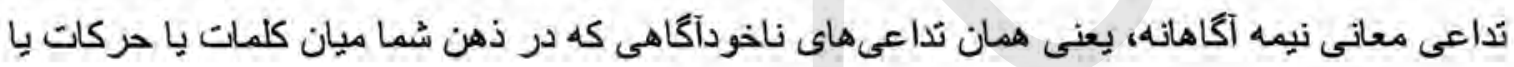

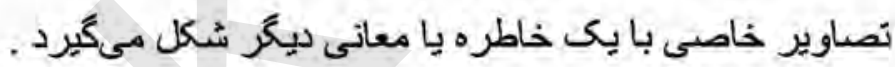

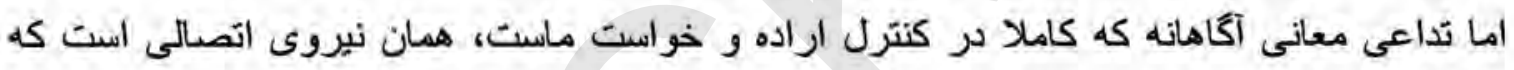

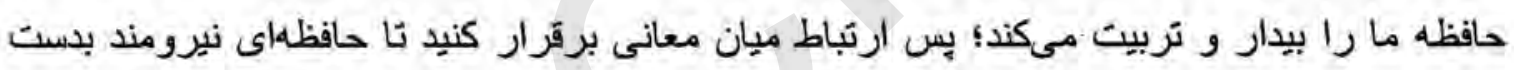

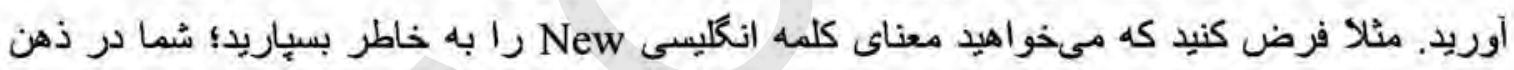

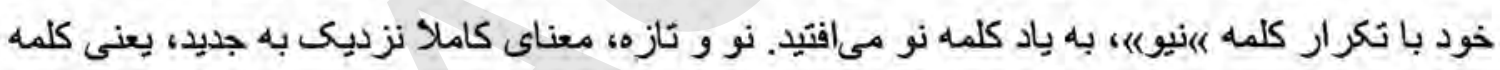

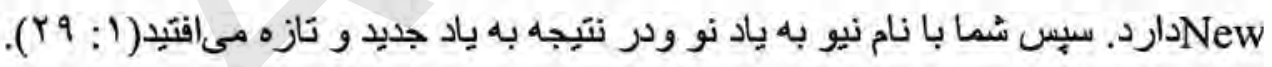

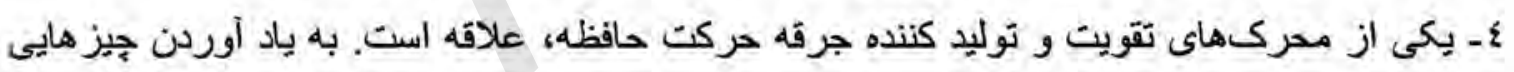

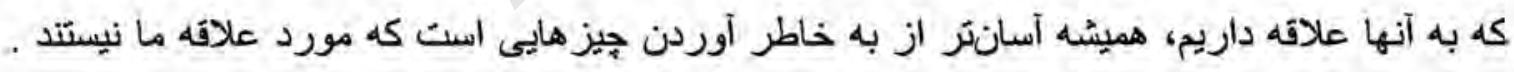

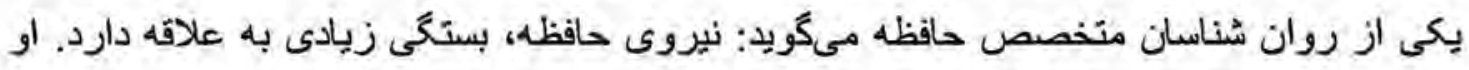

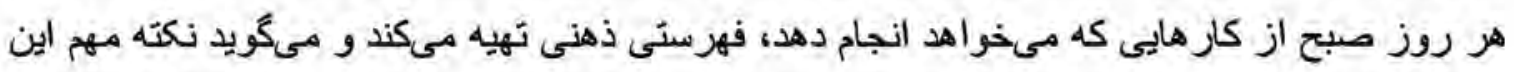

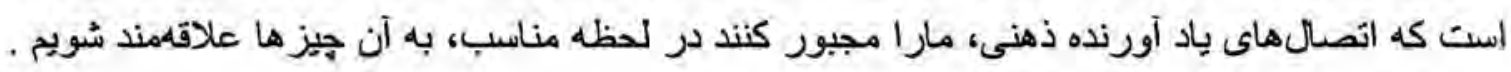

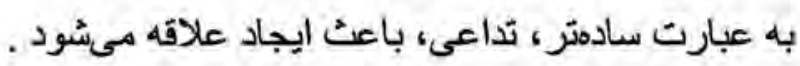

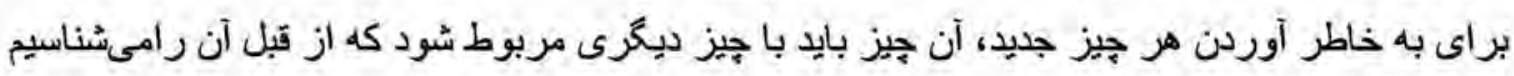

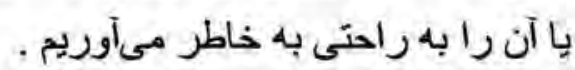

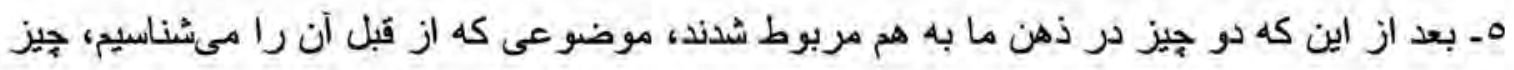

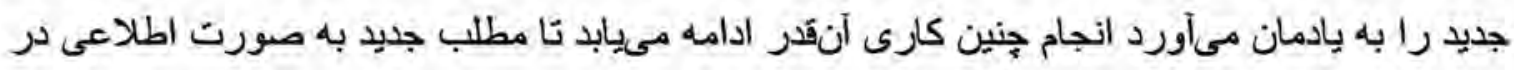

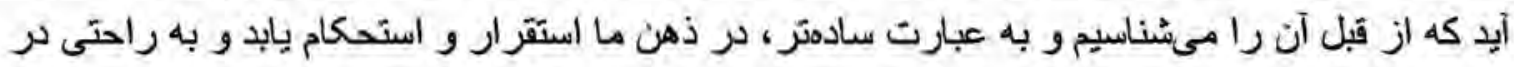


جرا ما به سادگى نقشه ايتاليا را به خاطر مىآوريم؛ اما به دشوارى ميتو انيمِ شُكل سرزمينهاى آلمان بيا

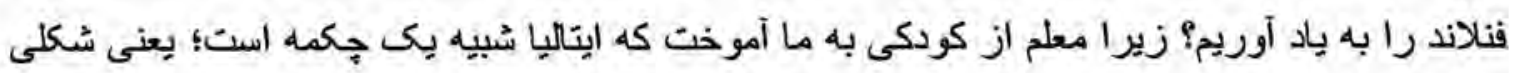
كه ما از قبل آن را مىشناختيخ. از قدرت تصوير ذهنى خود بيشتر استفاده كنبد! منخصصان فن حافظه مىگويند: هر جها به به نصوير

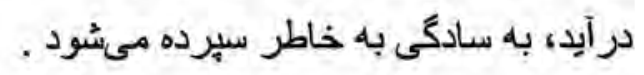

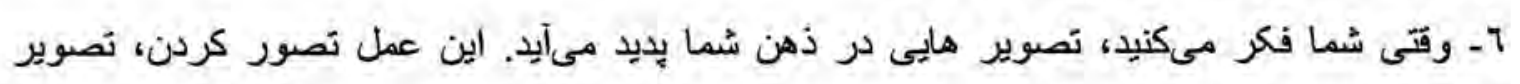

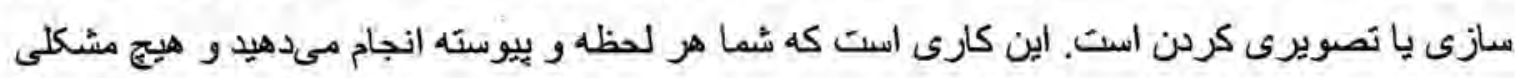
درباره آن نداريد.

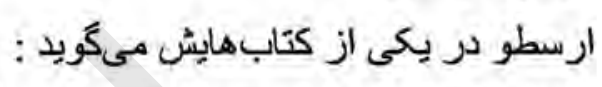

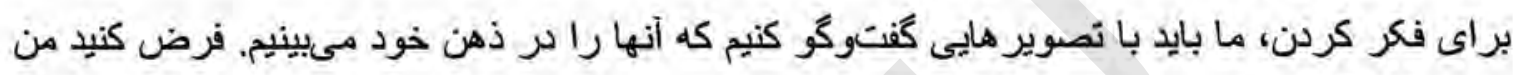

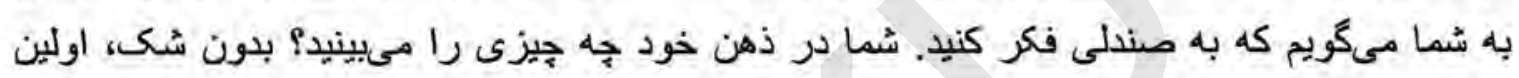

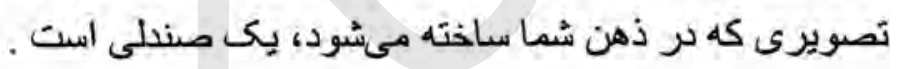

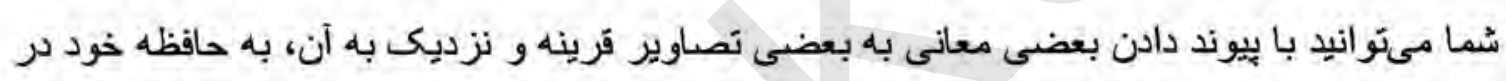

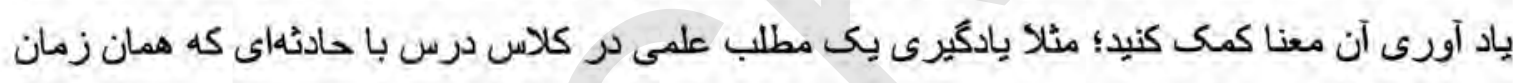

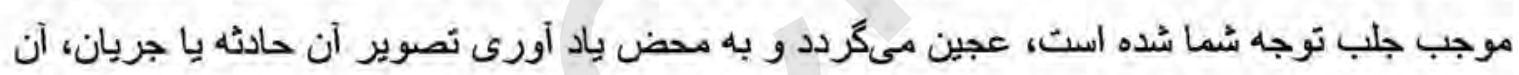

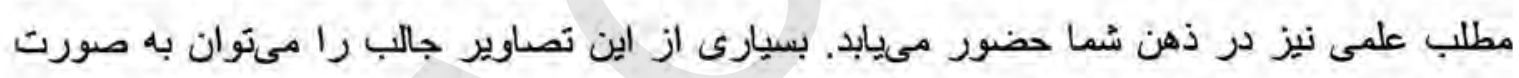

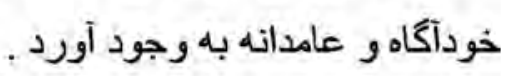

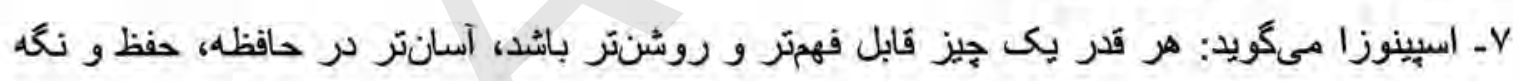

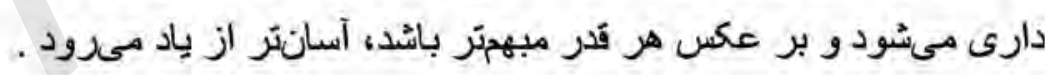

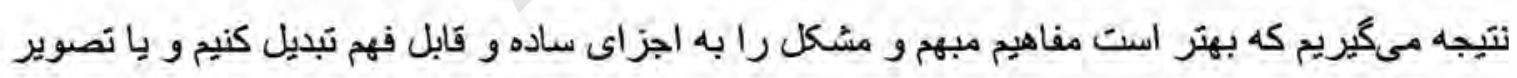

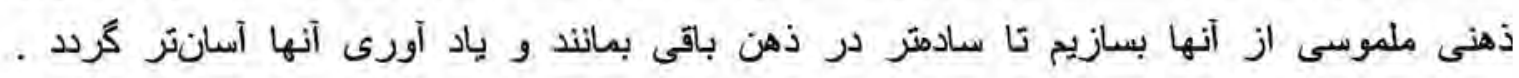

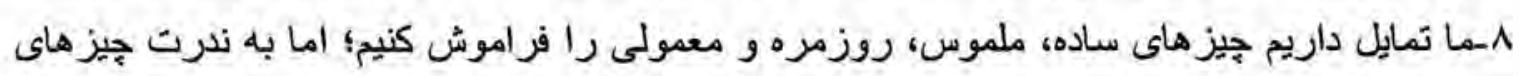

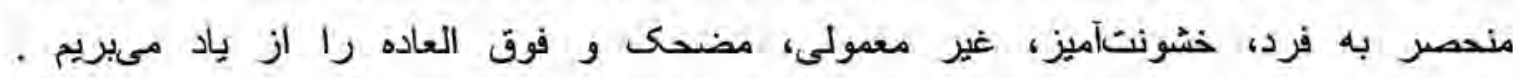

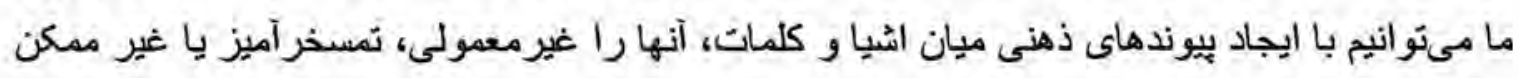

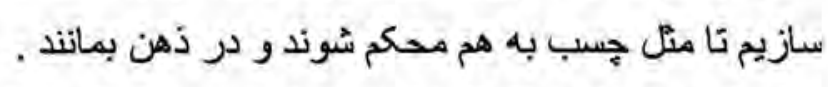

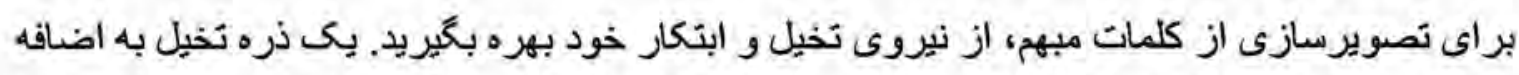

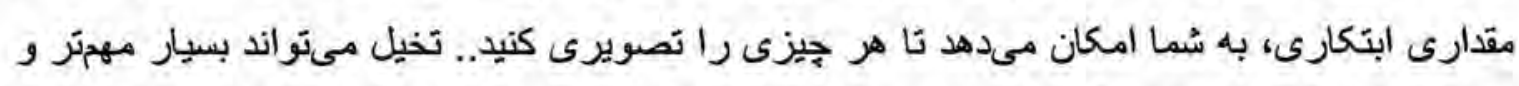

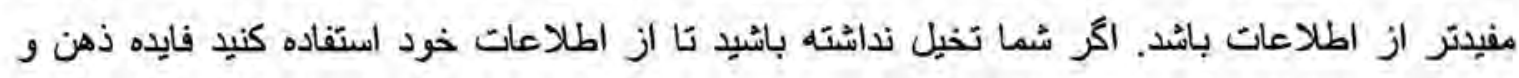

$$
\text { مغزجيست مغيتر }
$$

مثّلا براى به خاطر أوردن سورهاى از قرآن كريم كه سجده واجب دارند، اين كَونه خيلإيردازي كنيد: 
شبى در حالى كه ستاره در آسمان مىرخشيد، بدرم را ديدم كه در حال سجده، سوره بخشت را قرائت

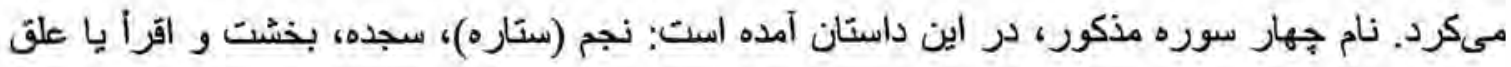

و-خوب مشاهده كردن در تقويت حافظه، كمك بزرگى است. نكاه كردن و ديدن،آسان است؛ اما به دقت

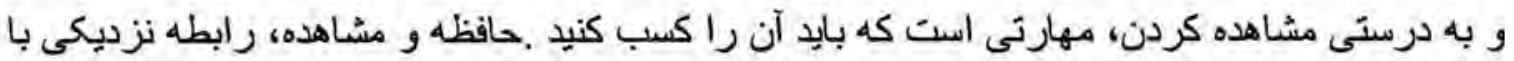

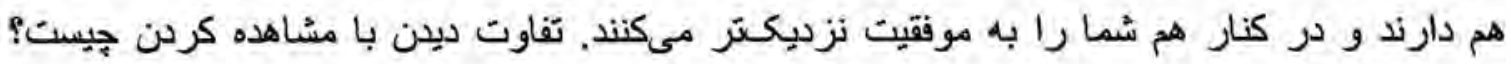
تفاوت آن است كه ما با جشُمان خود مىبينيم؛ اما با ذهن خود مشاهده مىكنيم؛ به عبارتى مشاهده

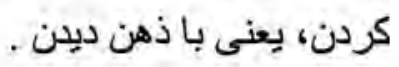
تنها قاعده براي مشاهده كردن خوب و حساس، دقت و توجه است. شما با تمرين آكاهانه يا نا آكاهانه،

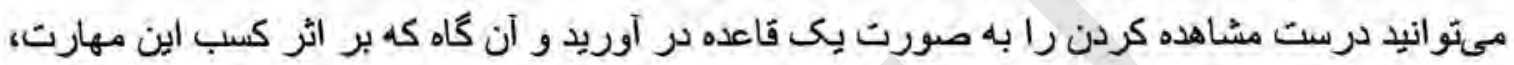
از هر معنايى يكى تصوير ذهنى دقيق و روشن و همر اه با جزينيات مر ذهن شما تشكيل شد، متوجها خواهيد شد كه جقدر در به خاطر آورن آن توانا هستيد و جه حافظه نيرومندى بيدا كردهايد .

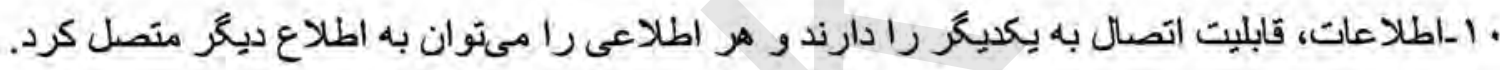

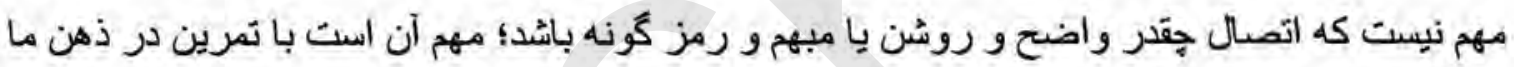

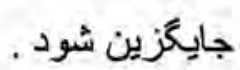

اطلاعات به هم منصل شدهاى كه شما زياد استفاده مىكنيد و در مدت كوتاهى به معلومات شما تبديل

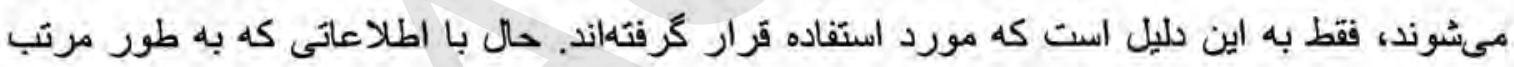

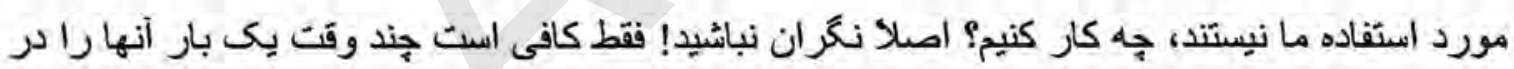
ذهن مرور كنيد. در اين صورت، وقتى كه به آنها نياز داريد، آن اطلاعات به باد شما مىآيند. اين

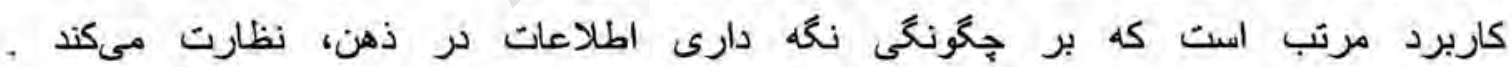

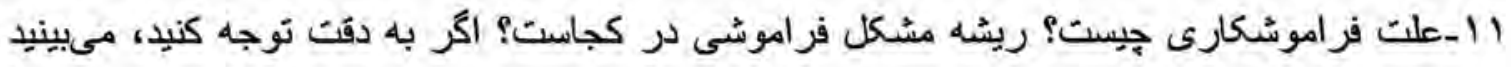

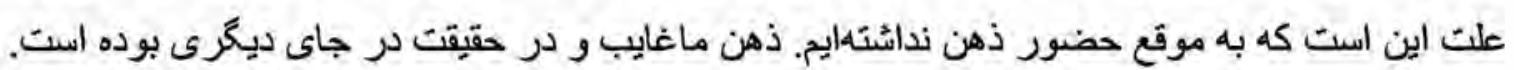

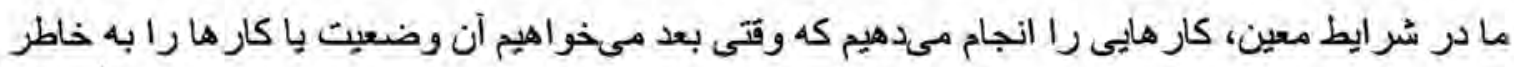

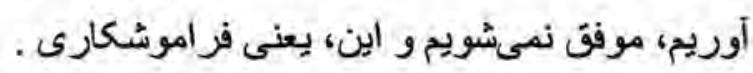
براى حل مشكل فراموشكارى، بايد مطمنن باشيد كه در لحظهاى كه داريد آن كار هاى معين را انجام

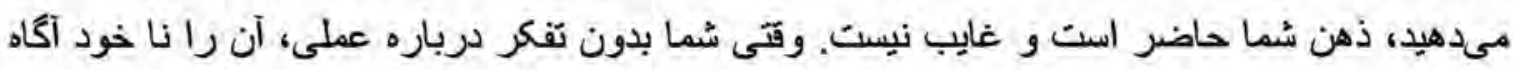

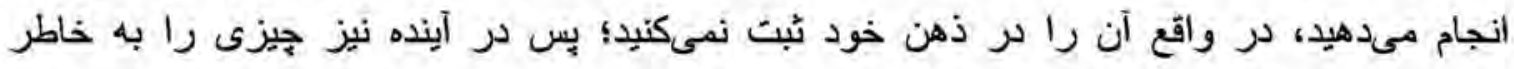

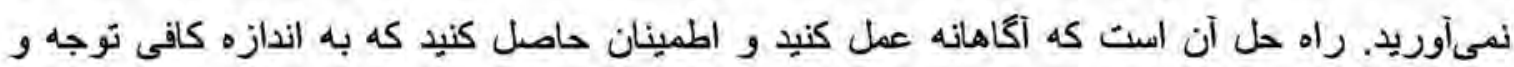
حضور ذهن داريد. 
rا - جهه كار كنيم كه مجبور نباشيّم يكى مطلب را بار ها و بار ها بخو انيم تا بتوانيم آن را به ذهن بسباريم

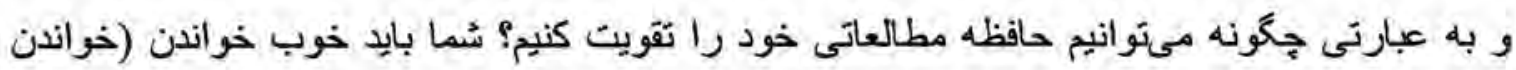
مؤر) را ياد بكيريد.

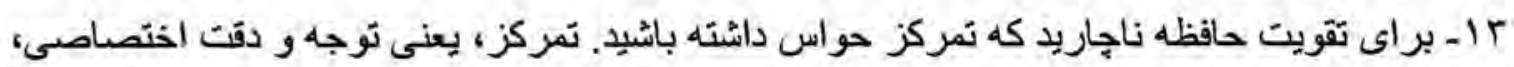

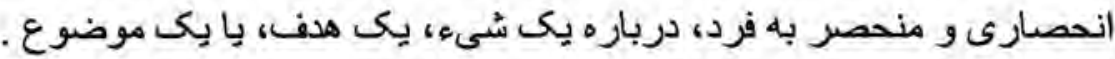

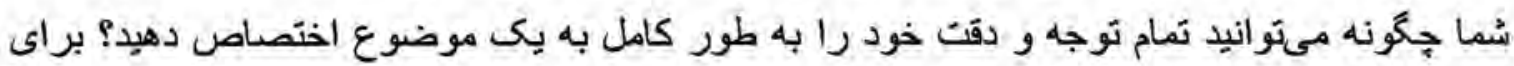
رسيدن به اين هدف، باليد قانون اصلى تمركز را به كار بيريد؛ خود را دركير كنيد.

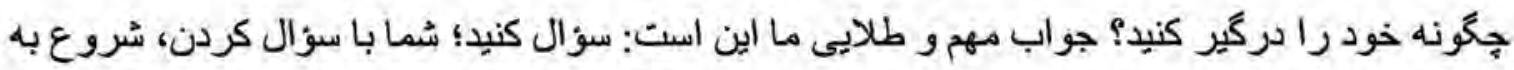
فكر كردن مىكنيد. وقتى مطالب را با هدف بافتَن باسخهاى معين براى بِرسشهانى معين بخوانيد، اين امر حافظه شما را در يادكيرى مطالب تقويت مىكند .

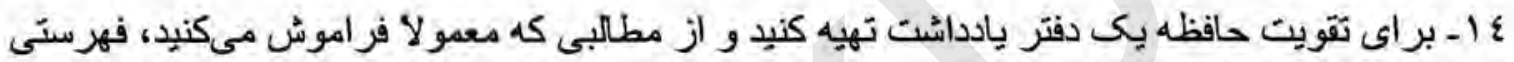
تهية كنيد. فهميدن اين كه جه مطالبى را فراموش مىكنيد، از آن جهت مفيد است كه ميتو انيد براى فراموش نكردن آنها بيشتر تمركز ايجاد كنيد. مشكل اساسى آن است كه ندانيد جه مطالبى را فراموش مىكنيل. اين روش فايده بزرخ ديخرى هم دارد. شما وقتى فهرستى از فراموش كارىهائ خود تهيه ميكنيد، خود را هم متقاعد مىسازيد كه حافظه شما جندان هم خراب نيست و فقط در موارد محدودى كه فهرست أن را در اختيار داريد، دجار مشكل هستيد و تازه مىفهميد كه بسيارى از موارد هم راه حل هايیى بسيار ساده و آسان دارند و در واقع شما از دو جهت مشكل خود راكوجكـتر مىكنيد. ماـ مطالبيى را كه ممكن است فراموش كنيد، به صورت سؤال در آوريد و در طول امروز جندين بار أن سؤال را خود بجرسيد. اغلب مساتل، با ايجاد سؤال در ذهن شما حكى مى فوند و تصوير سؤال، نا

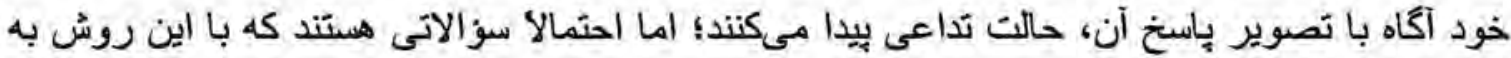

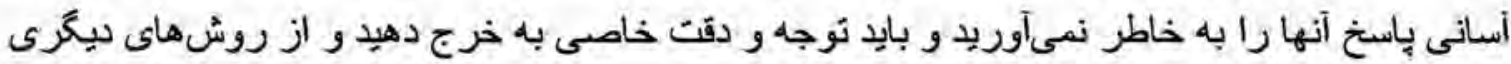
نيز استفاده كنيد.

17 ا- براى تقويت حافظه خود ميتوانيد از ديكران بخواهيد كه سوالاتى را كه احتمالا باسخ آنها را فراموش مىكنيد، از شما ببرسند. با تكرار اين تمرين، شما بر نقاط ضعف حافظه خود تسلط بيدا

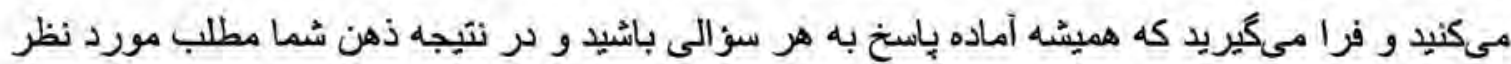
را به صورت آماده باش نكه ميدارد تا آرام آرام آن مطلب به دانستهايى ناب و دائم شما اضافه كردد .

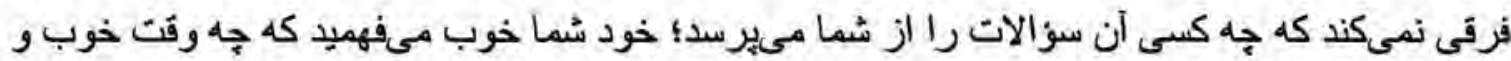

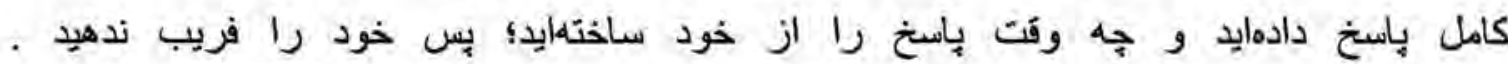


Vا يكى روش مؤثر ديكر براى تقويت حافظه آن است كه از مندهاى كمكى استفاده كنيد. شما مىتوانيد

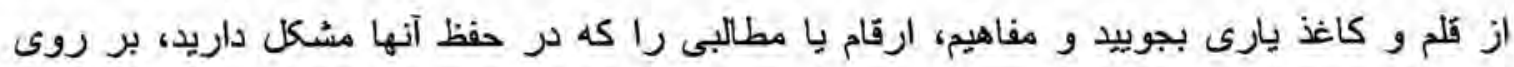
كارتهائ كوجكى بنويسيد و هر روز جند دقيقه را صرف باز نويسى فهرستها نماييد. دقت كنبد كه

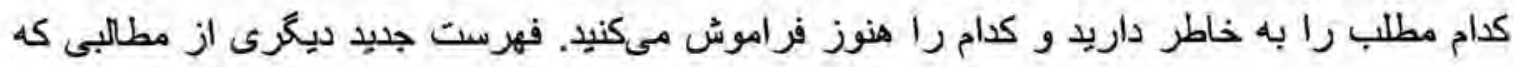

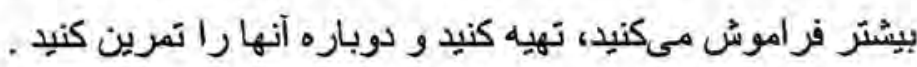
وقتى بدانيد جه مطالبى را فراموش كردهايد، به راحتى مىتوانيد در جهت حفظ آن اقدام كنيد. هر جه آنه

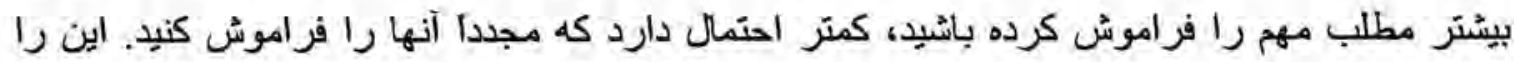

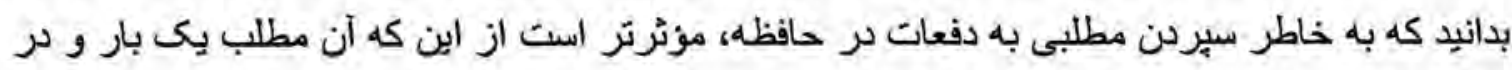
موقعيتى خاص در ذهن شما جاى كرفته باشُد .

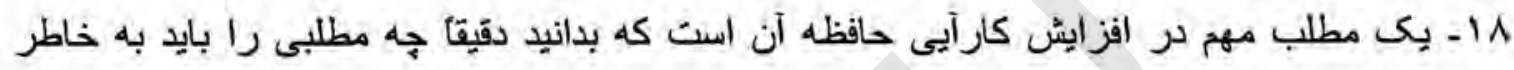
بسيّاريد. فهرستى از نكاتى كه بايد هميشه در ذهن آماده داشته باشيد، تهيه كنيد تا به سؤالات مربوطه به بهابه

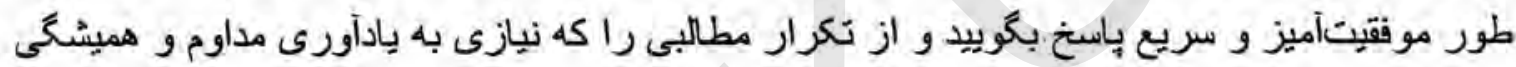

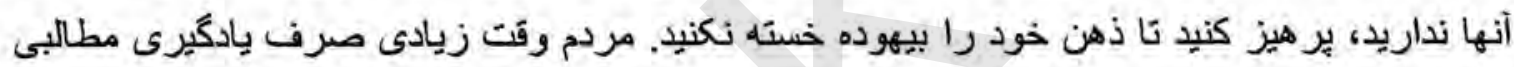

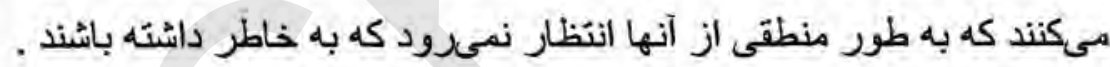

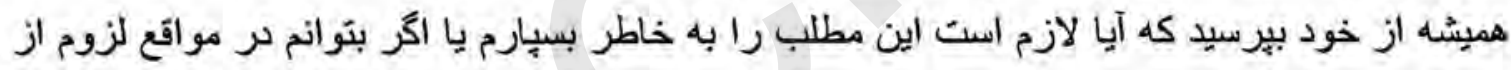

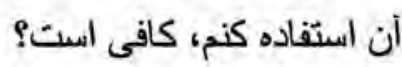
9 ا ـ از صدر المتألهين نقل مىكنند كه ميكفت: تعقل و تعلق هركز يكى جا جمع نمىشوند. او داستانى

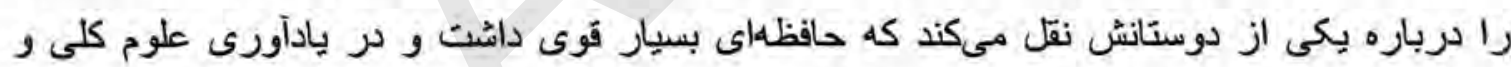

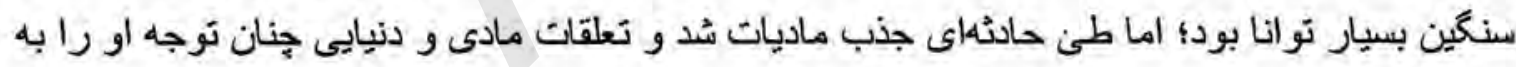

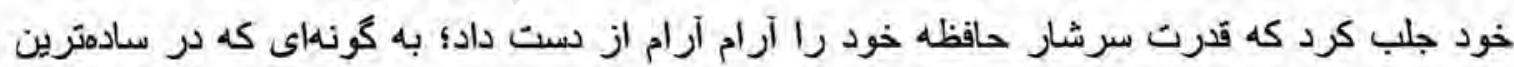
مسائل تعقلى در مى جماند. به عقيده ملاصدرا، هر جها مشغلههاى فكرى و تعلقات دنيايِى و افكار حاشيهاى از ذهن آدمى دور شود،

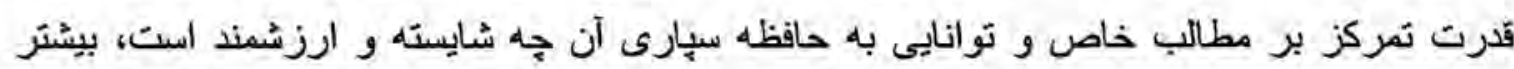
مئود.

•Y- بنابر آموزههاى السلامى نيز راهكارهايى براى تقويت حافظه وجود دارد كه قرار ذيل است:

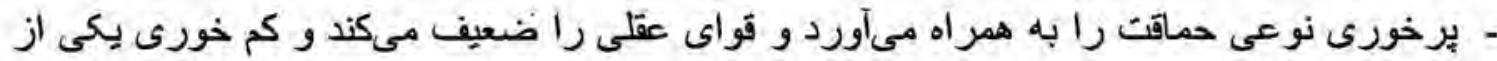

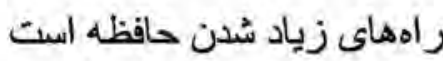
- زياده از حد آب خوردن و بدون احساس نياز آب نوشيدن، موجب كندى ذهن ميشود .

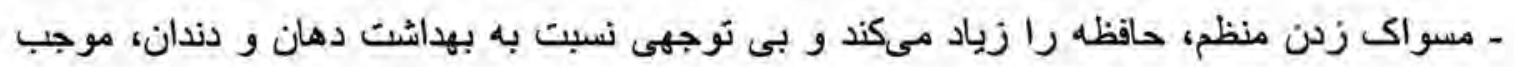

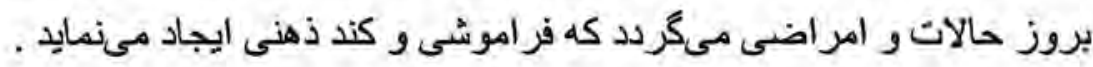


ـ شُستوشُوى بينى يا استشاق آب، بكى از راههاى تقويث و كثايش حافظه است. بديهى است كه اصلاح وضعيت تنفسى و رسيدن اكسيزن كافى به مغز، قدرث قواى ذهنى را افزايش ميدهد .

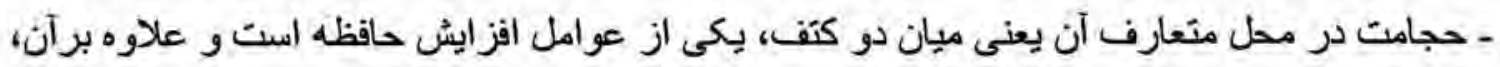

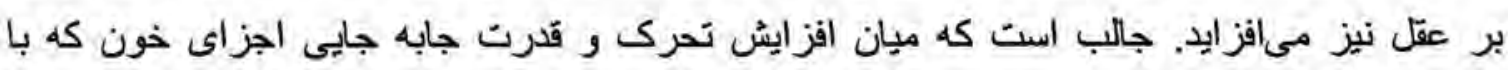

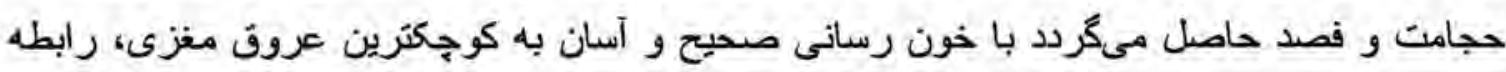
نزديكى وجود دارد. - خواب كوتاه قبل از نهار (قيلوله) از عوامل تقويت حافظه و ترك آن از عوامل فراموشى شمرده شُده است . n

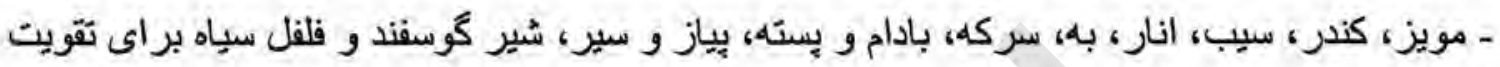

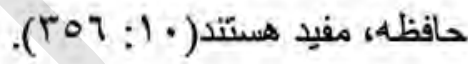

\section{راه هاى مفيد براى تقويت حافظه}

1 - جند راهى كه هم براى تقويت حافظه بسيار مفيد بوده و هم لذت بخش مىباشند. r ـ تا مىتو انيد بازل و جدول حل كنيد. بيشنهاد من جنول سودوكو مىياشد.

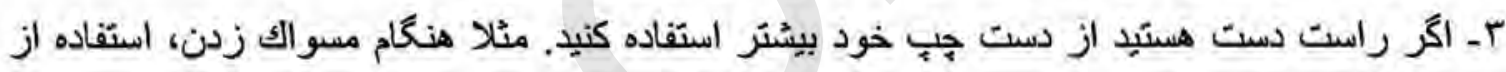

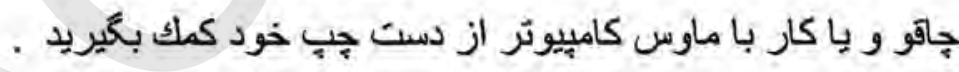

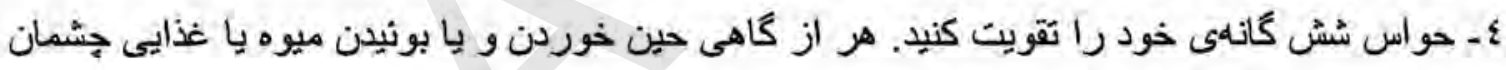

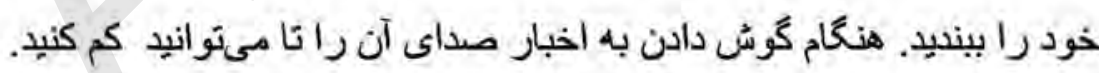

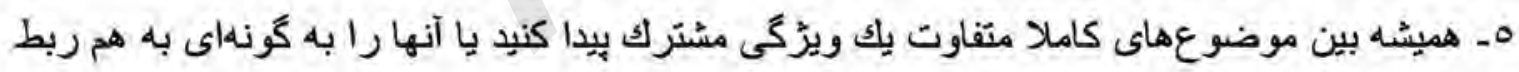
دهيد.

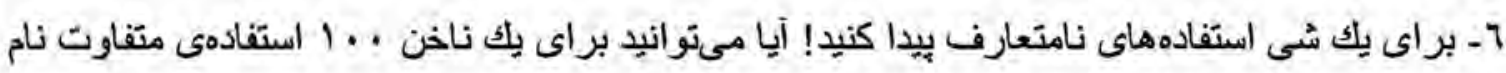

بيريد؟ لـ خلاقيت را بياموزيد.كار ها و بازىهاى خلاقانه زياد انجام دهيد. اتجام بازىهاى جمعى ماتند بانتوميم. حتما بيشنهاد مى مشود. A- عميق نفس بكشيد! يادكيرى طريقهى درست نفس كشيدن خيلى مهم است زيرا با تنفس نامناسب اكسيزرن كافى به مغز نخواهد رسيد.

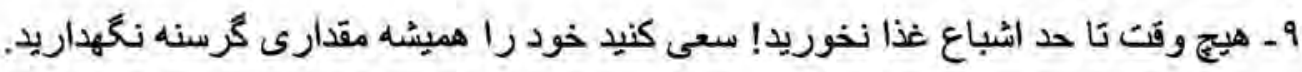
• ا - ورزش كنيد! وزرش كردن از عوامل مهم تقويت حافظه مىباشد. 
لا ـ در اينترنت زياد جستجو كنيد! حتى اكر موضوع خاصى در ذهن نداريد بازهم زمانى از روز را

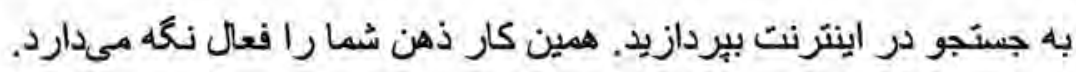

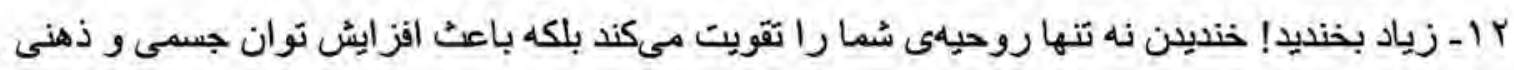
شما خواهد شد.

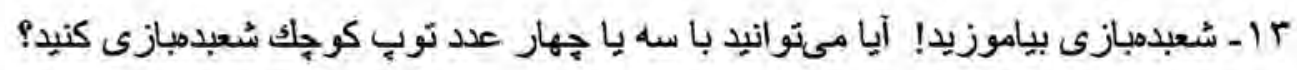

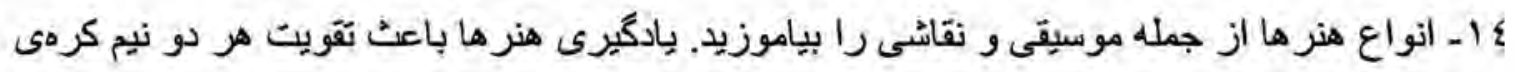
مغز مىشود.

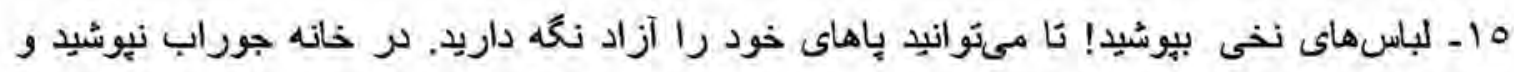
كفُ هايى كه منافذ دارند انتخاب كنيد.

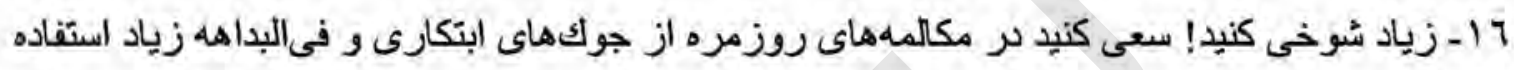
كنيد.

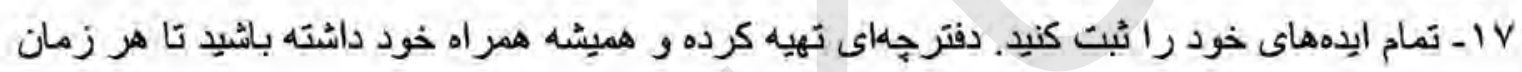

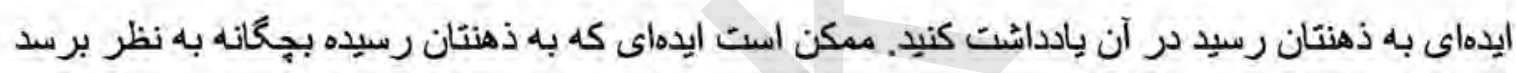

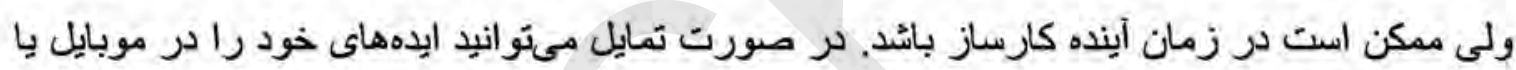
كاميبوترتان هم ذخيره كنيد.

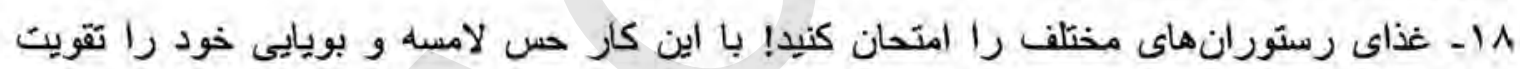
مىكنيد. 9 اــ خاطرات روز انهى خود را بنويسيد. سعى كنيد زياد بنويسيد. حتى مىتو انيد داستانى از زندگى خود تهيه كنيد. • r ـ يك زبان خارجى ياد بكيريد! حتما لازم نيست زبانى را ياد بكيريد كه بر كاربرد باشد. زبانى را.

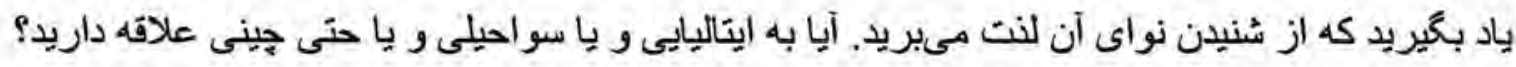

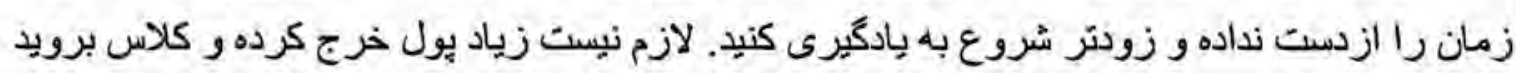
از طريق اينترنت هم ميتوانيد منابع بسيار عالى و رايكان نيز بيابيد.

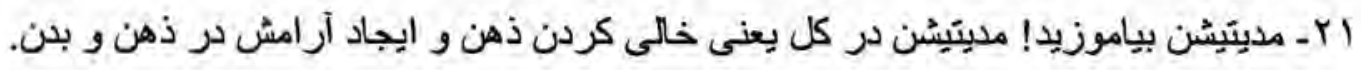

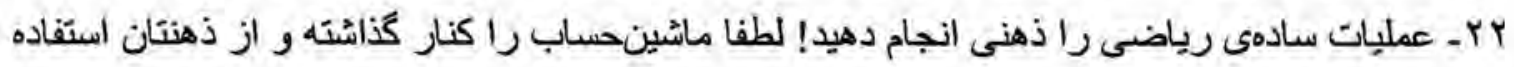
كنيد. rا بـ با طبيعت بيشتر ر ارتباط باشيد. كوه برويد و در جنكل با بارك بىهدف قدم بزنيد. ذهن خود را

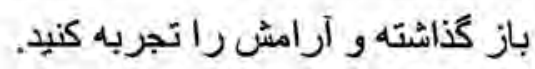

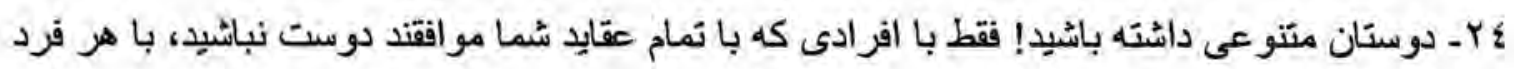
در هر سنى و با هر تفكرى ارثباط دوستانه داشته باشتبد. 


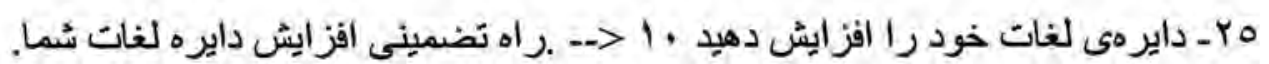
דr - سعى كنيد بك متن را هم از هب به راست هم از راست به جهب و هم از بالا به هيايين بخوانيد. لr ـ تلويزيون را خاموش كنيد! آيا مى توانيد يك ماه بدون تلويزيون زندكى كنيد؟ اكر ارادهى اين كار راديد.

ي - فورأ دست به كار شده و تلويزيون را به انبارى انتقال دهيد! تأثيرى كه اين كار بر روى زندكى شما خواهد داشت توصيف نشدنى است! من سه سال و نيم بدون اين جعبه سبرى كردم و وقتى ياد دورانى كه تلويزيون منبع اصلى سركرمىام بود مىافتح وحشت زده مىشوم!

سنت توماس اكيناس ، سه قانون اوليه تداعي ارسطو را احياءكرد:

ا-قانون تشابه : خاطره مشُابه با تاثير معيني به بِاد مي ماند. r-قانون عكس يِا منضناد : اكر دو با جند تاثير ، آنتي تز يكديكر باشند داشتن يكي سبب ياد آوري ديكري مي شود. ب-قانون همزماني يا همراهي : اكر دو يا جند تاثير همزمان اتفاق بيافتند ، بروز يكي سبب ياد آوري ديكري مي شود . بنابراين براساس نظريات داده شيده مي ثوان كفت حافظه عبارت است از كنشي كه احياي تجارب كذشَّه را در بر مي كيرد . يا يك استعداد همخاني در بخاطر سباري رويدادهاو اطلاعات و همجنين ياد آوري آنهاست بِ حافظه قَابليت رشد ، تقويت و برورش را داشته و بيس از همه به بكاركيري و تمرين نياز دارد .حافظه شبيه عضله مي باثد كه با تمرين كردن برورش يافته و تقويت مي كردد و مر صورت عدم بكارگيري سست و ثتبل مي شود. در اين مقاله قواعدي را بيان مي كنيم كه شما را در داشتن يك حافظه خوب ياري مي كنند . همجنين تكنيكهاي ساده و در عين حال كاملا" هوثر و كاربردي را ارانه مي دهيم كه بس از مطالعهه و يادكيري و در صورت بكاركيري آنها شاهد تحول بسيار جشمكيري در روند بخاطر سياري مطآب خواهيد بود. تقويت و بهبود حافظه همان يادكيري بهتز است ـ تقويث حافظه بعني رعايث اصول و قو انين حاكم بر يادكبري، اكر قوانين حاكم بر يادكيري را خوب رعايت كنيم بهتر ياد خواهيخ كرفت و ر نتيجه احساس مي شود كه كارائي حافظه بالا رفته است بس حافظه ما تقويت شده است ثقويت حافظه با برورش حافظه همان عوامل موثر بر باد آوري است كه روان شناسان به عنوان روشهاي برورش حافظه.

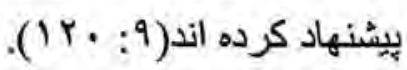

قبل از بيان روشهاي موثر در بخاطر سياري، اصول حاكم بر بادكيري راذئر مي كنيم كه عبارتنداز: مرحله اول - توجه : اولين كام در جريان هريادكيري توجه است. 
مرحله دوم - زبان كرداني : كام دوم در يادكيري ((زبان گرداني )) مطالب مه است . زبان كُرداني عبارت است از تبديل مطالب شُنيده ِيا خوانده شده به زبان مشخص و معني دار ـ اين كار را مي توان

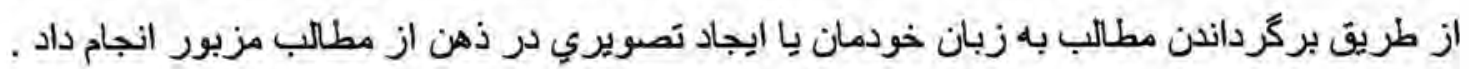

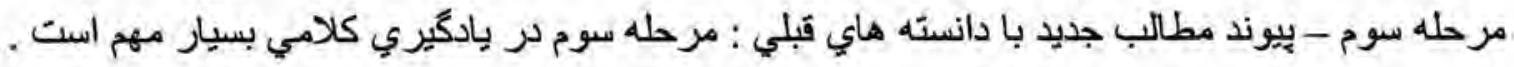

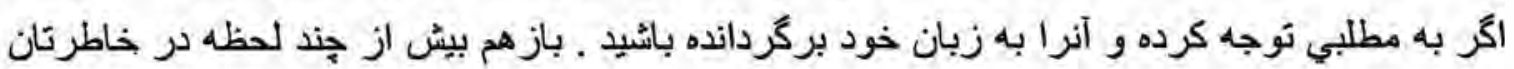

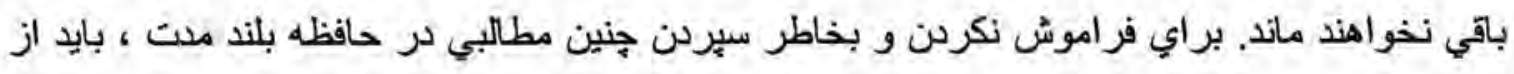
ميكاتيسم يبوند استفاده كرد. منظورازييوند ايجاد ارتباط بين مطالب جديد و دانسته هاي قبلي است.

\section{راههاي بهبود حافظه}

الف : اصول استفاده از حافظة

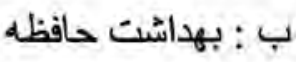

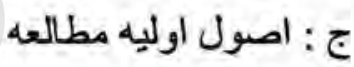

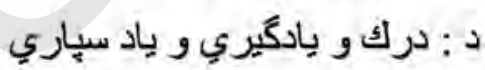

\section{الف ـاصول استفاده از حافظه:}

1ـ آموزش: به وسيله آموزش مي توان عمل فراكيري يا بهره كيري از حافظه را كه يك فعاليت مستقيم و قابل كنترل است افز ايش داد.

r-علاقه: اكربه موضوعي علاقمند باشيد بهتر آن را ياد مي كيريد.موضوع مورد مطالعه و همجنين ميزان علاقه اي كه خواننده نسبت به مطلب دارد ، در بخاطر سِّاري آن مطلب در حافظه تاثيز زيادي

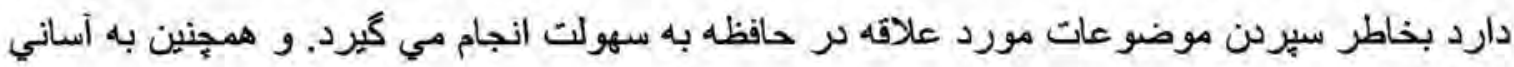

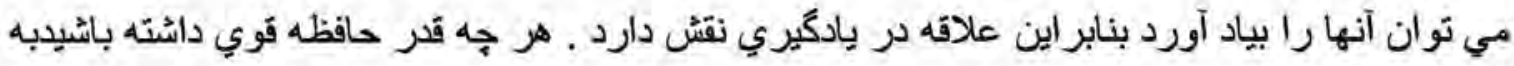

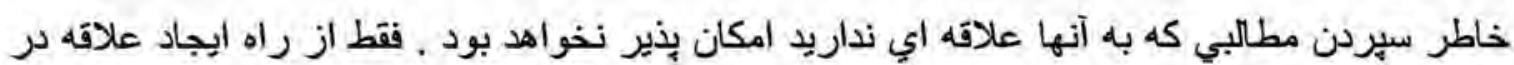
خود مي توانيد از عهده اين كار بر آييد.

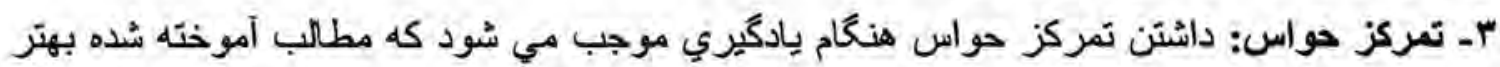

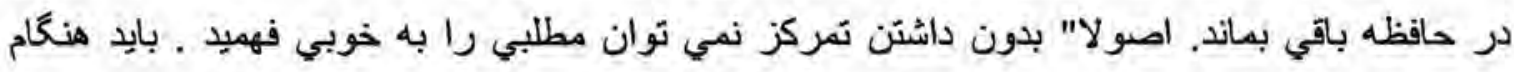

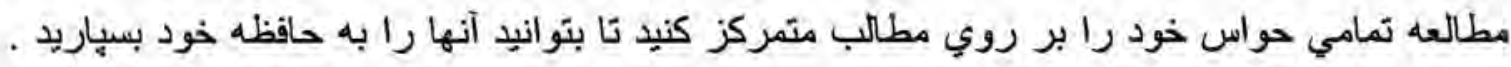
براي ايجاد تمركز بايد شرايط مطالعه را نيز رعايت كنيد ـ در واقع بار رعايت شرايط مطالعه موقعيت مناسبي را براي تمركز و بادكيري بهتر مطالب ايجاد مي كنيد. 
ع- طبقه بندي مطلب مورد مطالعه (ارتباط ): يكي از اصول حاكم بر حافظه اصل ارتباط و بهز بيوستكي است بعني ، حافظه مطالب مرتبط و به هم بيوسته را بهتر بر خود جاي مي دهد و هر جقدر آموخته هاي شما بيشتر با همديگر ارتباط داشته باشند به همان نسبت به خاطر سياري و بياد آوري آنها آسانتر خواهد بود. حافظه به شكل زنجيره اي عمل مي كند. بنابراين مطالب بايد به صورت ز نجيره اي، يبوسته و در ارتباط باهم در آيند تا كار بخاطر سباري و از آن مهمتر، عمل بياد آوري راحت باشد. ه خوب درك كردن ( درك مفاهيم ): بروفيسور ربروت توكه مي كويد : (درسي كه كاملا" فهميده شود از قبل بياد كرفته شده است .)) بس اكر مطلبي را بجاي حفظ كرن بفهميد ،بهتر رر حافظه ضبط ور بايڤاني مي كردد.واصو لا" اكرمتني به خوبي درك شود ، كمتر فراموش مي شود . قبل از آنكه بخواهيد مطلبي را حفظ كنيد ، ابتدا بايد آن مطلب را مورد بررسي و تجزيه و تحليل قرار دهيد ـو هنكامي كه أنرا به خوبي درك كرديد بخاطر بسياريد. \- اعتماد به نفس: اعتماد به حافظه نخسئن كام تقويت حافظه است ، بايد به قوي بون حافظه خود اعتماد داشته باشيد. بايد از كاربرد كلمات و جملاتي كه موجب تضعيف حافظه مي شوند جدا"؛ خودداري كنيد . حنما" از كفتن جملاتي نظير حافظه ام ياري نمي كند ، حافظه ام ضعيف شده است .... خودداري كنيد. جزرا كه با كقتن اين جملات ، به خودتان تلقين مي كنيد كه و اقعا" حافظه تان ضعيف شده است ، مر آن صورت حافظه نيز به ياري شما نمي شُتابد. نتيجه : آنجه كه در ذهن شماست نتيجه يادكيري و بخاطر سباري صحيح است . بخاطر سباري مهارتي قابل كسب است حافظه را مي توان طوري تربيب كرد كه موثرتز انجام وظيفه كند .كساني كه به روشهاي يادكيري خود ثوجه بيشتر دارند و هنگام به خاطر سيردن مطلبي ثركز حواس داشته باشند و مطالب را با نظم وترتيب در حافظه ضبط كنند آن موقع به خاطر آوري مطلب در آنها آسانتر خواهد

\section{ب - اصول بهراشت حافظهه: بود}

جگو نه مي توان يك حافظه بهتر داشت ؟ يادكيري و حفظ مطالب به جند صورت امكان بذير است ؟

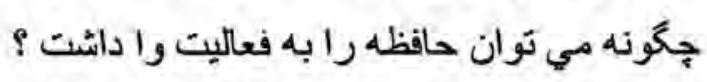

ذهن آدمي همجون ديكر اعضاء بدن احتياج به مواد غذاني و مراقبت دارد ـ. همانطور كه به وضع يوشس خود دقيق هستيم بايد به بهداشت و سلامت رواني حافظه و مغز دقت كنيم . هنكام كار و هون فعاليثهاي ذهني ،براي سلامني و جلوكيري از فرسودكي زودرس حافظه بايد موارد بهدائي زير ران رعايت كرد:

اـ تاثير تغذيه مناسب بر حافظه ( اعم از اكسيجن و غذا): تغذيه مناسب يكي از مهمترين عوامل در افزايش كار ايب حافظه است . كلسيم و منيزيم و فسفر سه عنصر اساسي و ضروري براي حافظه به 
شُمار مي آيد و بايد با تغذيه مناسب مانند :جوانه كندم ، لبنيات ،جكر ، بادام ، سبزيجات و تخم مرغ مي

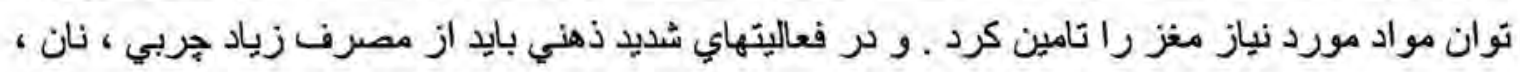

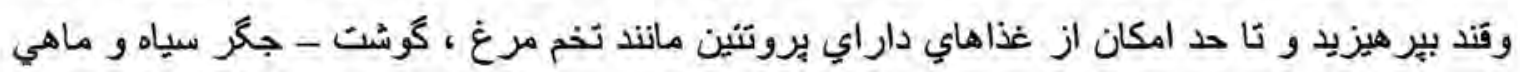

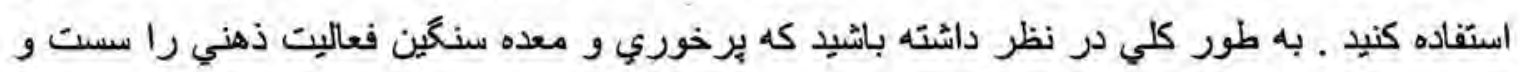

$$
\text { محدود مي كند. }
$$

r- تاثير دخاتيات و مواد مخلر: استفاده از سيخار و دخانيات نه تنها موجب خستخي زودرس جسم و

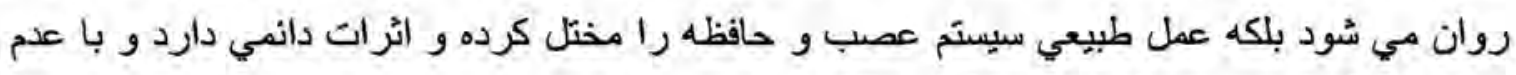

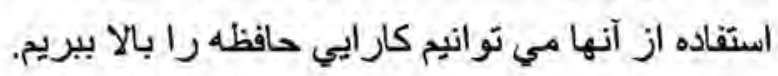

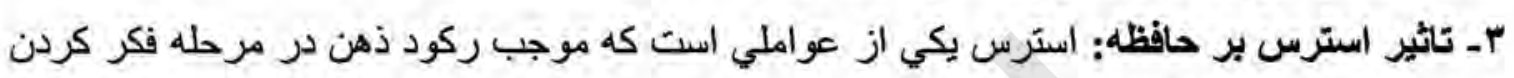

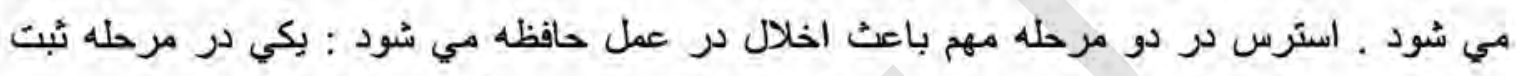

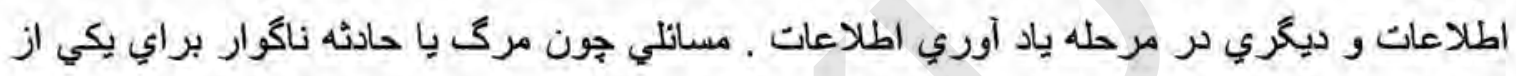

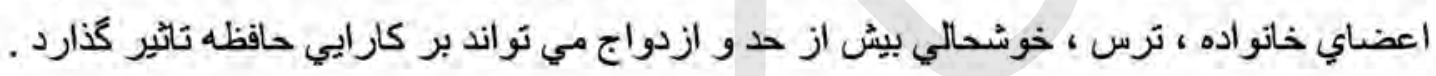
توجه : اكثر دانش آموزان موقع امتحان بيشتر به طرف بايين خيره مي شود كه اين عمل كار بايي حافظه

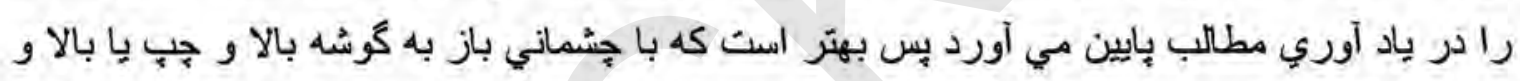

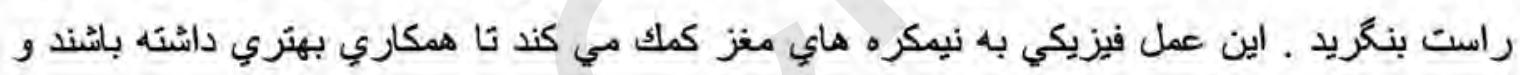

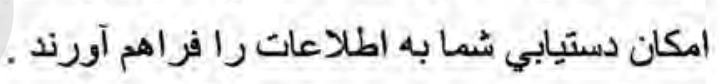

؛ـ تاثير استراحت در حافظه: هنكام مطالعه نبايد خسته باشيد ، اكر احساس خستخي مي كنيد كمي بايد

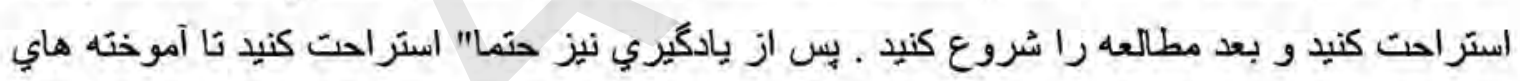

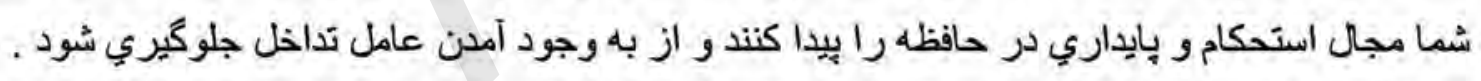

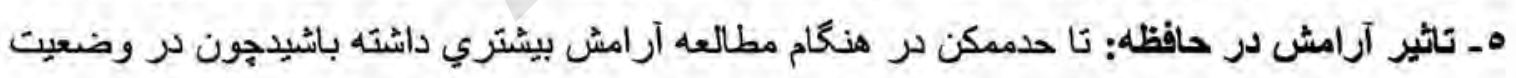

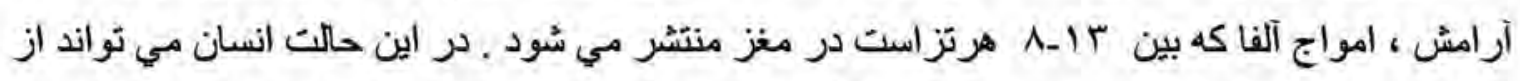

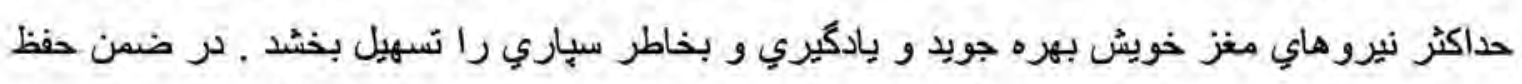
آرامش و حالث طبيعي اركانيسم كاركرد طبيعي مغز و اعصاب را نيز تسهيل مي كند (1' : . ـ).

\section{ج- اصول اوليه مطالعه:}

اولين اصل قبل ازشروع مطالعه جيست ؟ جكُونه مي توان بازده مطالعه را افزايش داد ؟ نحوه

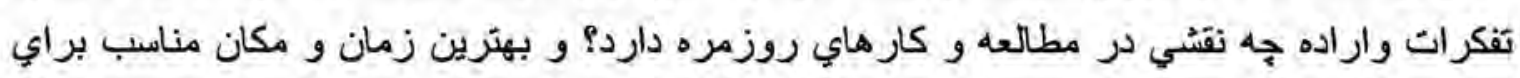

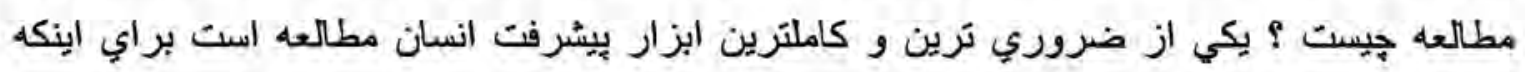


بتوانيد مطالعه بهتري داشته باشيد تا بازيابي و بخاطر سباري آن أسان باشد اصول زير را بايد رعايت نماتيد: اـهاف: تيري كه بدون هدف رها شود بي تتيجه خواهد بود. قبل از شروع مطالعه بايد حتما" هيف

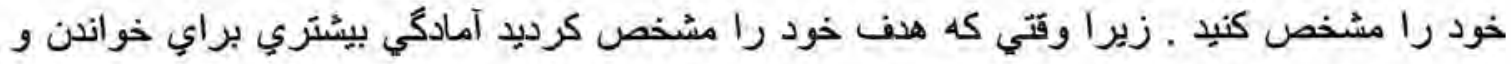

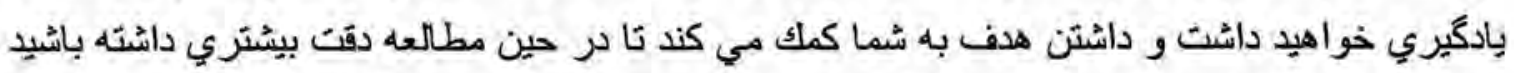

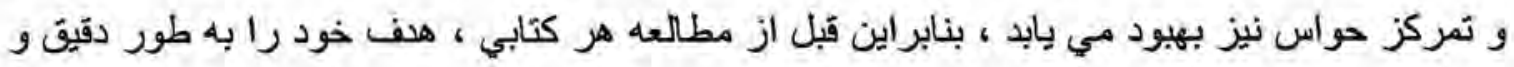
واضح بيان كنبد. Y-برنامه ريزي : برنامه ريزي درسي ، اين امكان را مي دهد كه بهتر ودر زمان مخصوص به خودش

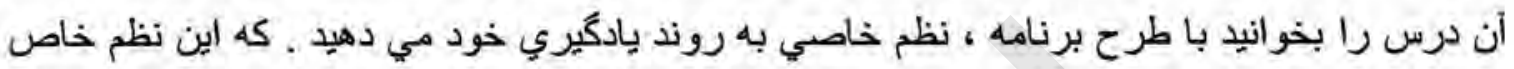
بمكانيسم حافظه در بخاطر سباري مطلب كملك مي كند. r- مكان و زمان مطالعه: مكان مطالعه بايد آرام بوده ،از نور كافي برخئ برخوردار بائد و زمان مطالعه

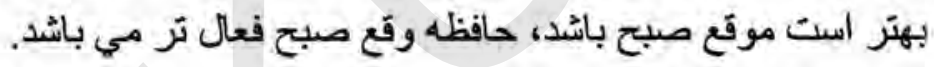

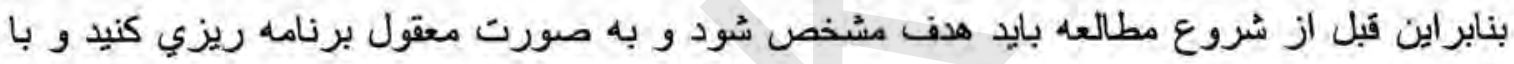

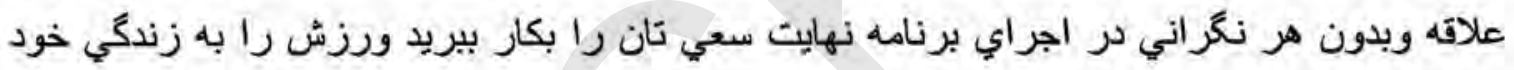

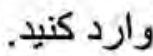

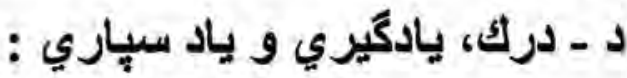

دراين مورد سوالاتى قابل مصرح است كه جرا براي به خاطر سيردن مطالب يك كتاب ، جند بار آن را مي خوانيم و بِ از مدتي مطالب را فراموش مي كنيم ؟ أَيا فهميدن دليل برياد داشَن براي هميشه

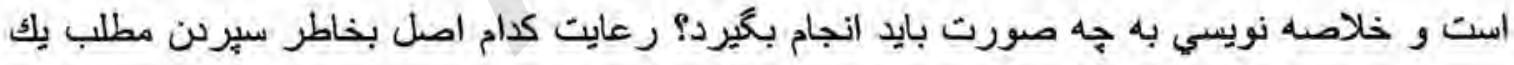

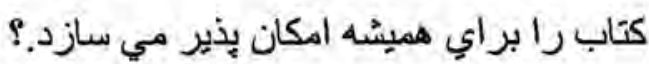
براي اينكه مطالب خوانده شده را در حافظه بلند مدت خود ضبط كرده و براي مدتهاي طولاني -

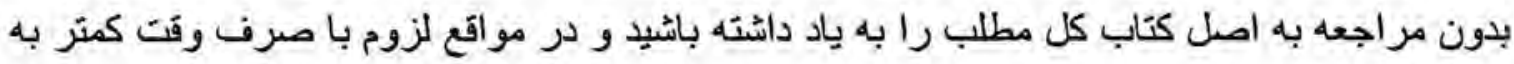
ياد بياوريد مي توان از روش خلاصنه كردن و الكو هاي يادآوري استفاده كرد: 
ا_اصل الكُوهاي يادآوري: عبارت از درك مطلب و متن خوانده شده ونوشُنَ آنها به صورت كلمات

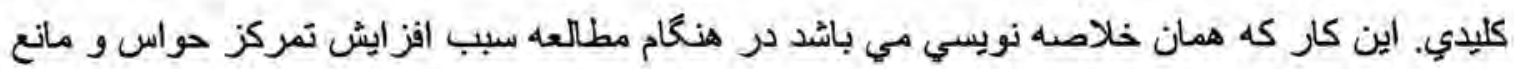

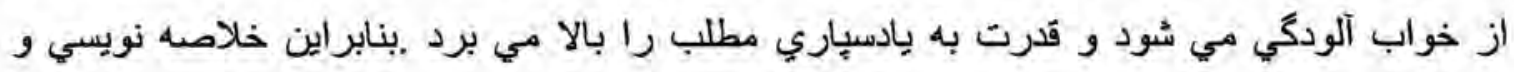

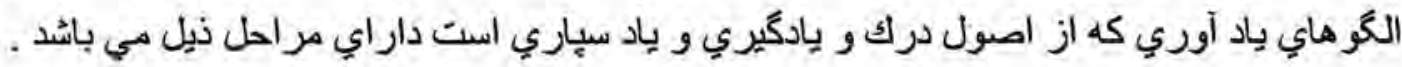

الفـ يادداشت برداري : در يادداشت برداري نكات بصورت اصلي و فرعي نوشُشَه مي شوند بدين

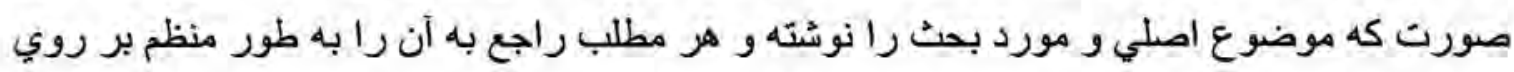

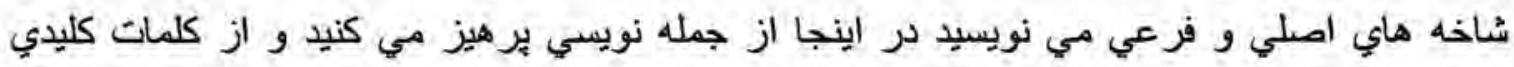
استفاده مي كنيل . با توجه به اينكه ياداشت برداري و خواندن دو عمل مجزا مي باشد و هر ير يك كار

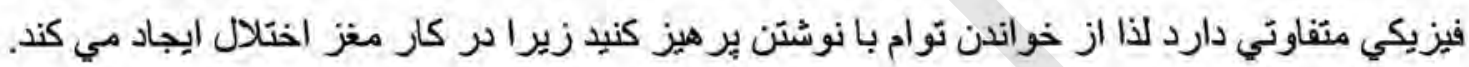

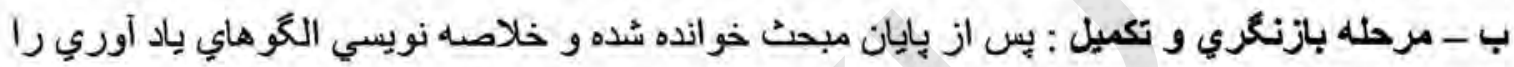
بررسي، و آن را تكميل و مرتب كرده ودر مرتب كردن سعي كنيد كلمات كلبدي باهم ارتباط بيشر بردي داشته باشن. ج - مرحله تعريف: بعد از آن دو مرحله متن اصلي را كنار كذاشته با نخاه كردن به الكو هاي ياد آوري و كمك كرئن از اطلاعات موجود در مغز آنجه را باد كرفته ايد با صداي بلند توضيح دهيد. اين مرحله مغز شما را يوياو فعال خواهد كرد. د - مرحله تكرار و مرور: مرور و باد آوري از فراموشي مطالب جلوكيري مي كنند و حفظ و ياد

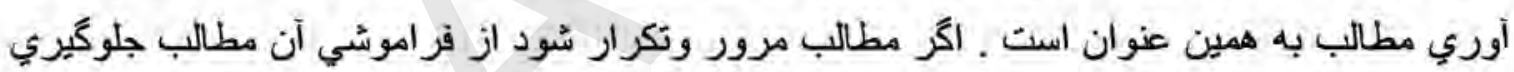
مي شود. بيش از 9\% از مطالب خوانده شده بعداز ع ع ساعت فراموش مي شوند در حاليكه مرحله مرور

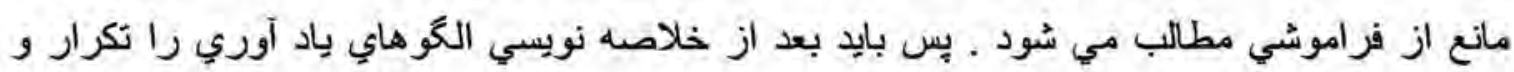

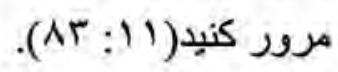

\section{اصول ديگز بازسازي و يادآوري}

ا- تداعي: براي بازسازي و يادآوري موضو عات جليد بايد تداعي مناسب بين آنها بر قرار كنبد، جون

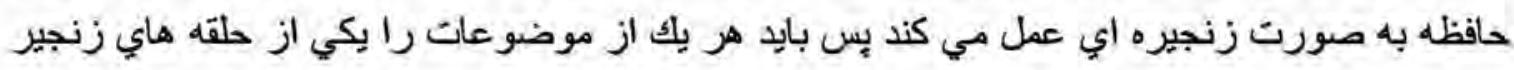

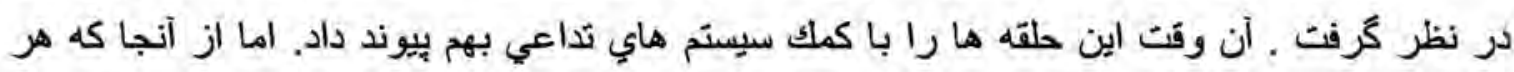

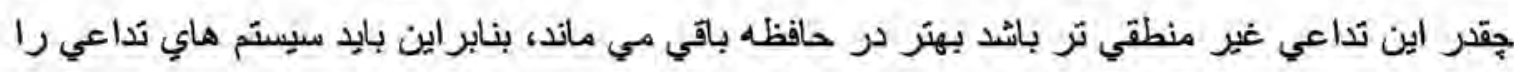


به صورت مضحك مبالغه آيز رنغهاي غير واقعي در آورد تا موضوعي بهتر در حافظه باقي بماند .

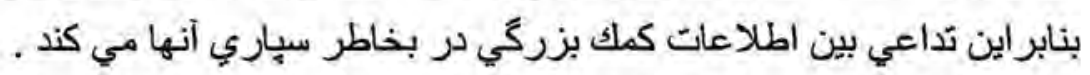

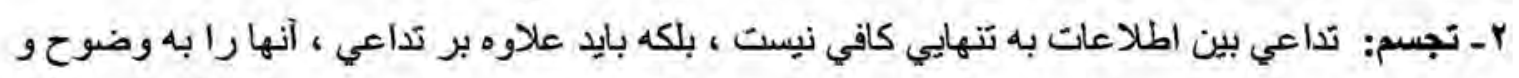

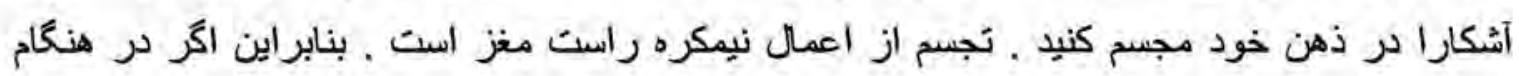

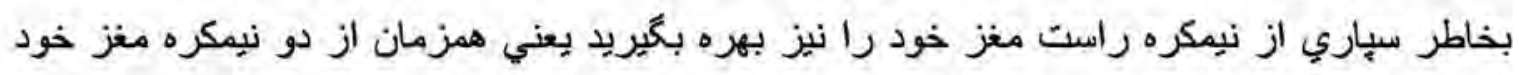

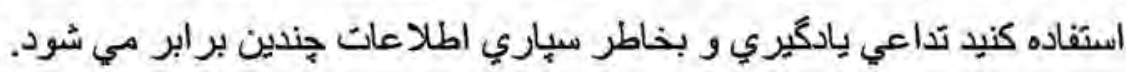

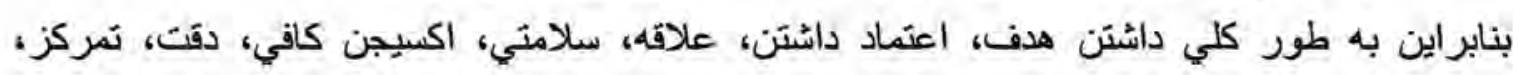

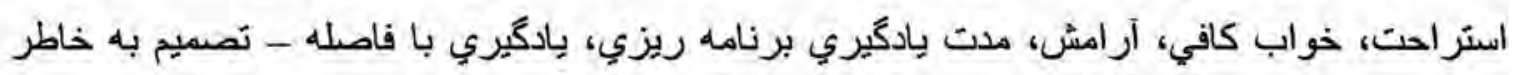

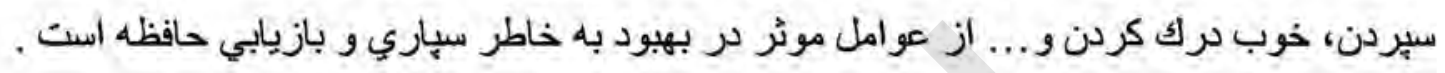

\section{تمركز تكنيك تقويت حافظه}

تمركزتكنيكى موثر برايى تقويت حافظه است. به طور كلى رشد حافظه همكام با رشد تمركز حواس

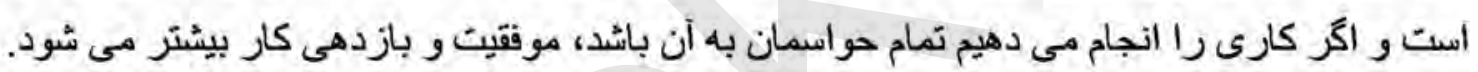

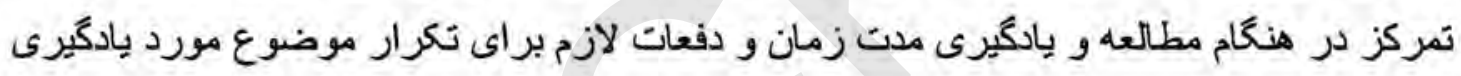

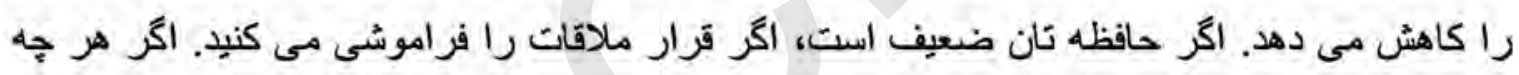

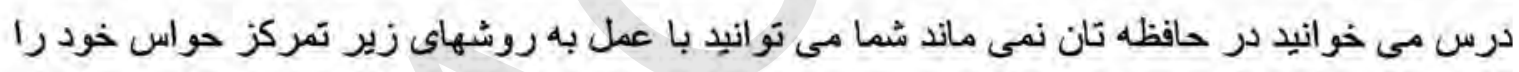
رشد داده و حافظه تان را تقويت كنيد.

1- اعتماد به حافظه: اولين اصل تقويت حافطه اعتماد به حافظه است، بِ به تو اتاى مغز و قوى بودن

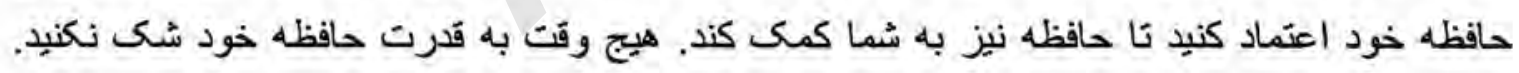

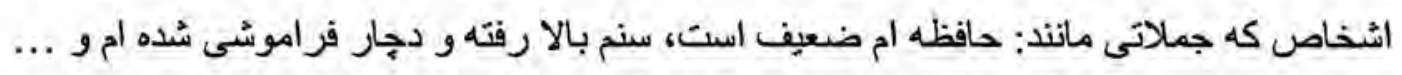

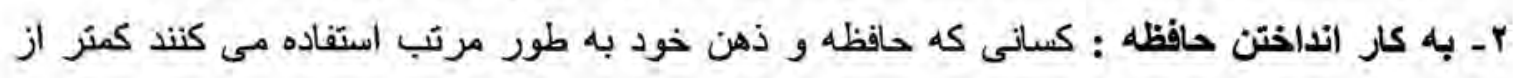

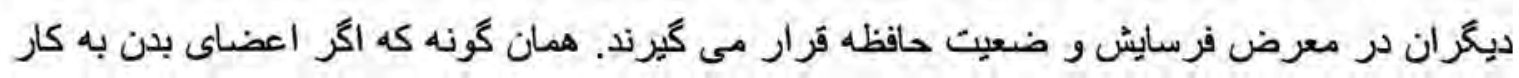

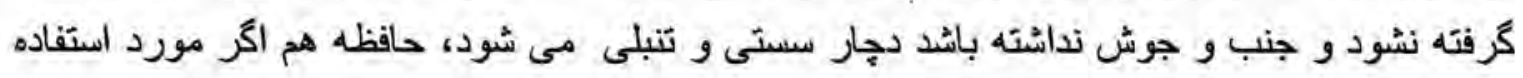
قرارنكيرد ضعيف مى شود.

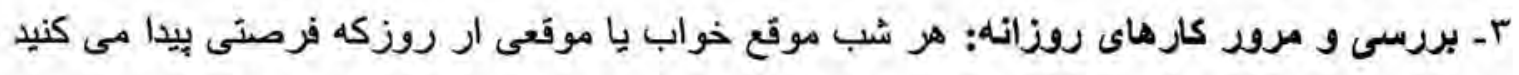

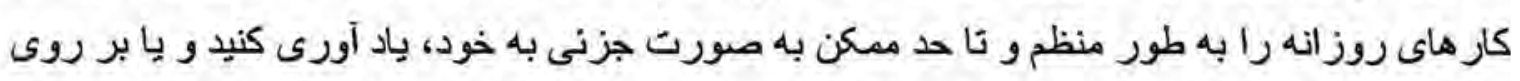

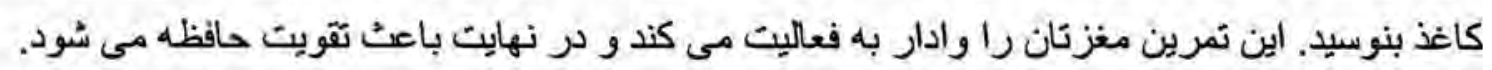


أـ تمركز: تمركز يعنى دقت روى بيك موضوع خاص بـى آنكه افكار ديكرى ذهن رابه خود مشُغول

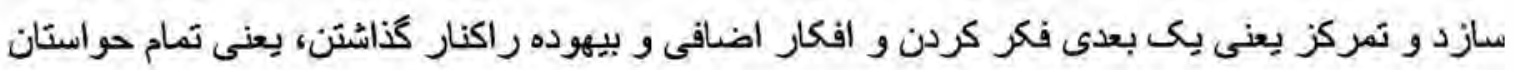
بر بـى مطلب خاص بيردازد.

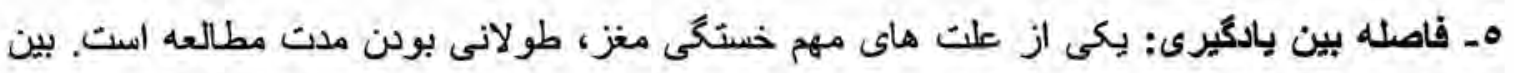

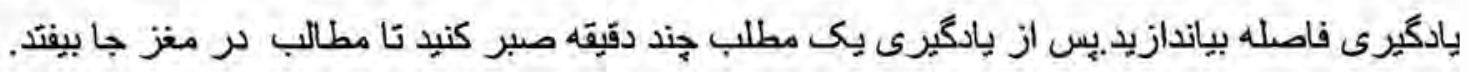

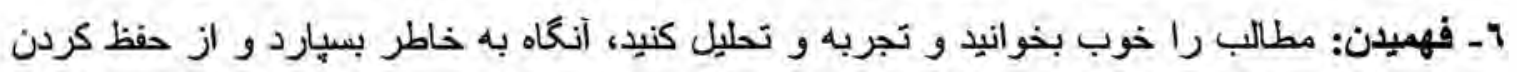
بدون درك معنى خوددارى كنيد.

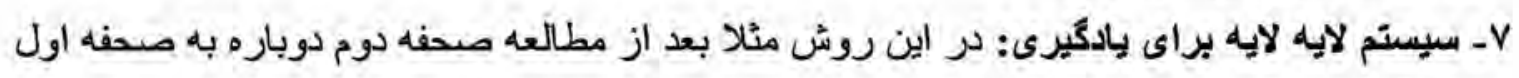
رجوع كنيد.

Aـ تنفس عميق: يكى از روش هاى مهم براى تقويت حافظهف تنفس عميق استبا كمك تنفس عميق

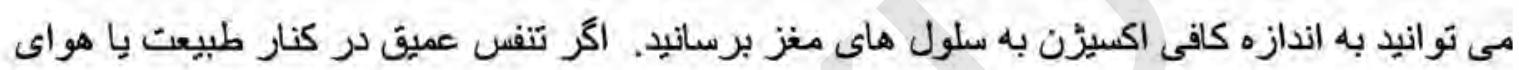

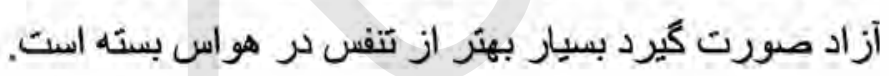

9- تعيين هاف: يكى از عوامل مهم عوامل ايجاد تمركز حواس و افزايش دقت در هئكام مطالعه،

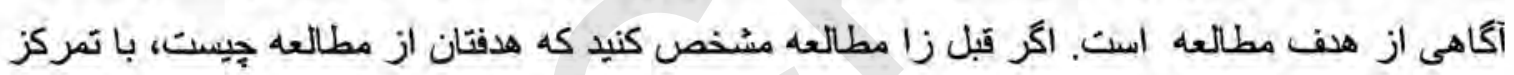
و كنجكاوى بيشترى مطالعه خواهيد كرد.

\section{راههاى تقويت حافظه كوتاه مدت}

حافظه كوتاه مدت، اطلاعاتى كه تنها به مدت كوتاهى مورد نياز است را در خود جاى ميدهد. اين نوع

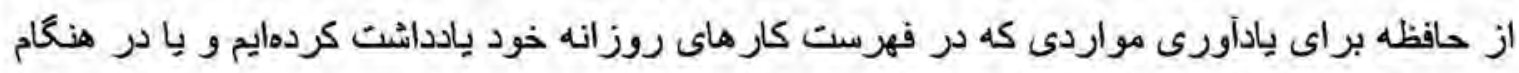

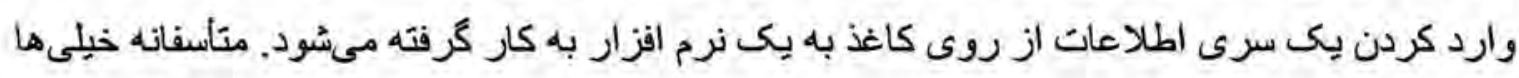

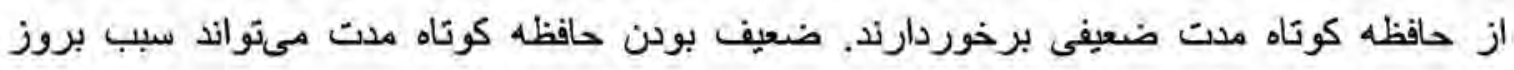

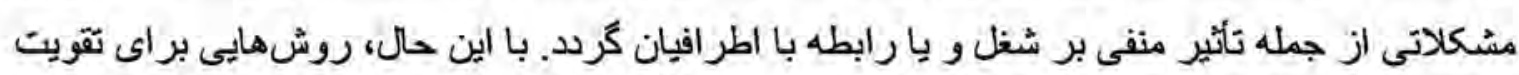

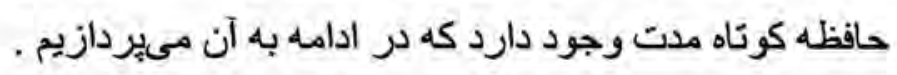

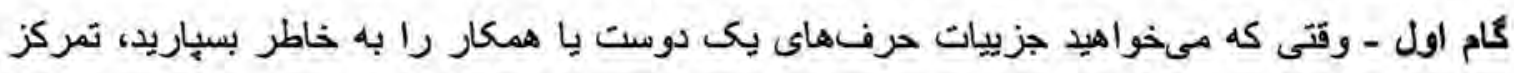

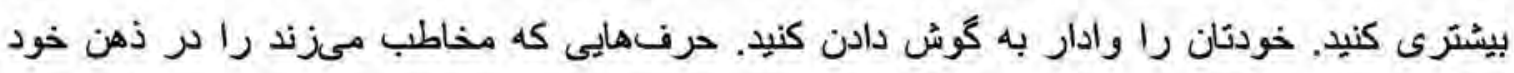

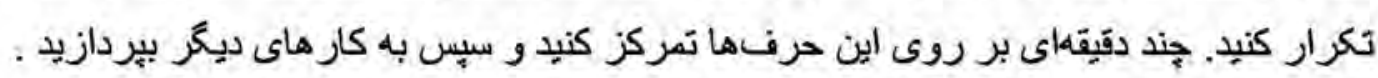

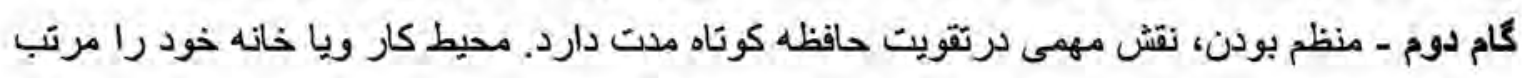

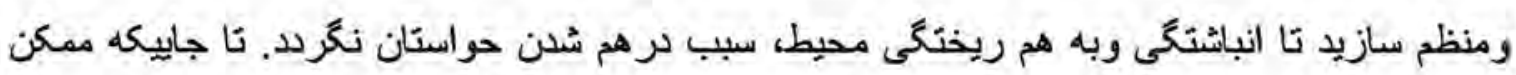


است محيط خانه يا كار خود را ازنظم دهيد تا بدين شكل ذهن تان آماده دريافت اطلاعات و فراخوانى

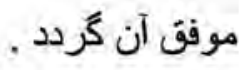
كام سوم - بين اطلاعات جديد و اطلاعاتى كه در كذشته داشتهايد، ارتباط برقرار كنيد بمثلا اكر قرار

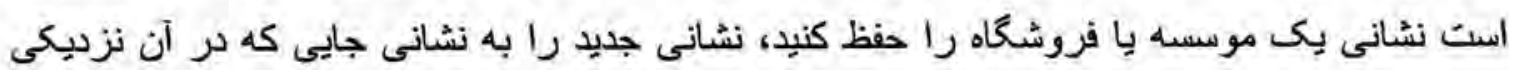

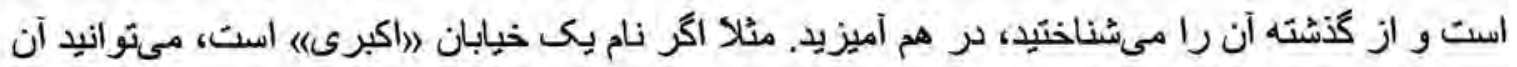

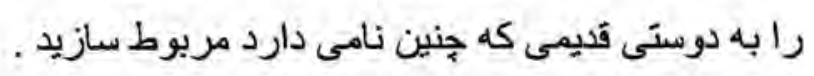

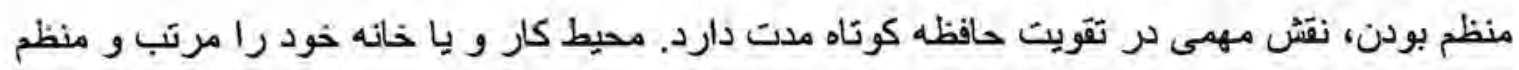
سازيد تا انباشتكى و به هم ريختخى محيط، سبب برت شندن حواس تان نكردد .

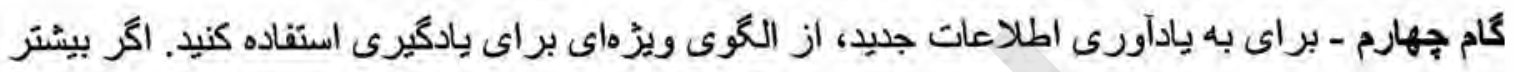

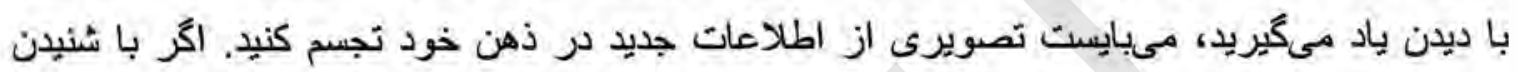

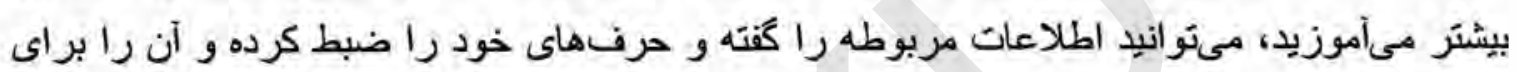

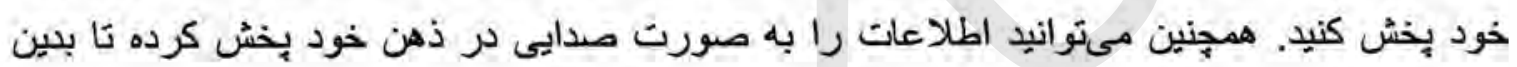

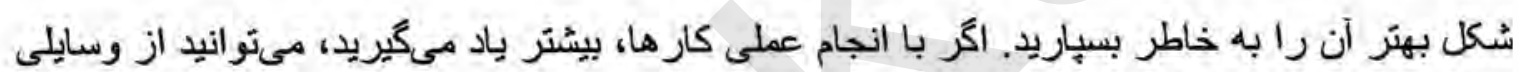
كه قابل لمس هنتند، نظير فلش كارت استفاده كنيد.

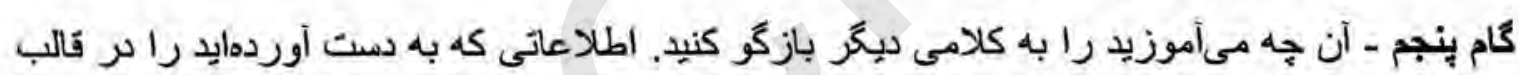

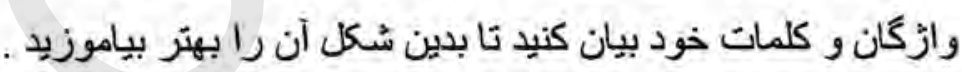

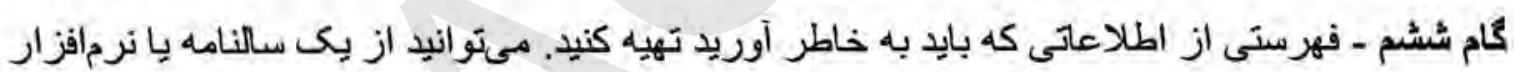

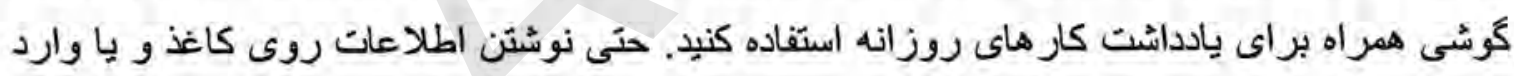

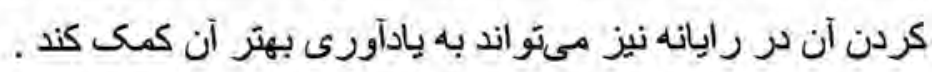

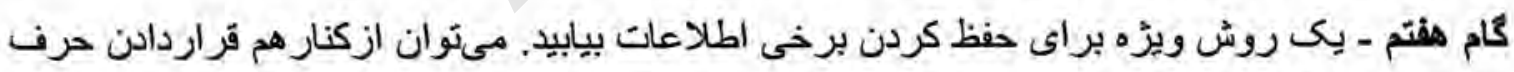

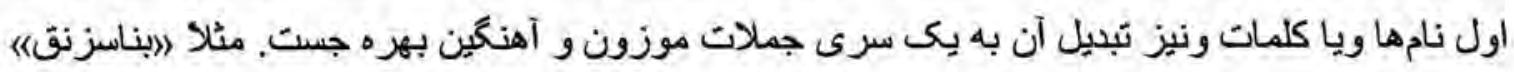

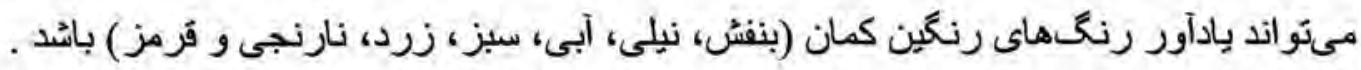

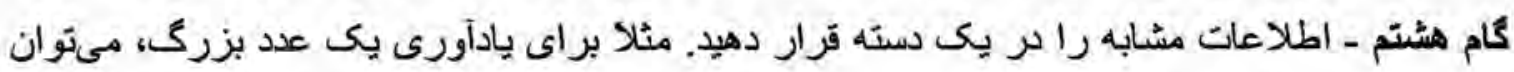

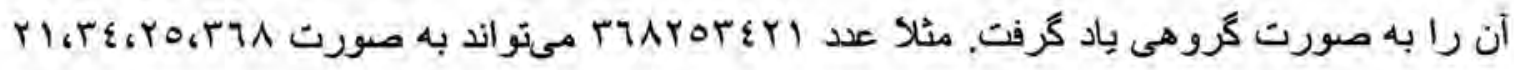
باشُ (9): (170) (170). 


\section{روش هاى تقويت حافظه با مواد غذاى و ويتامين ها}

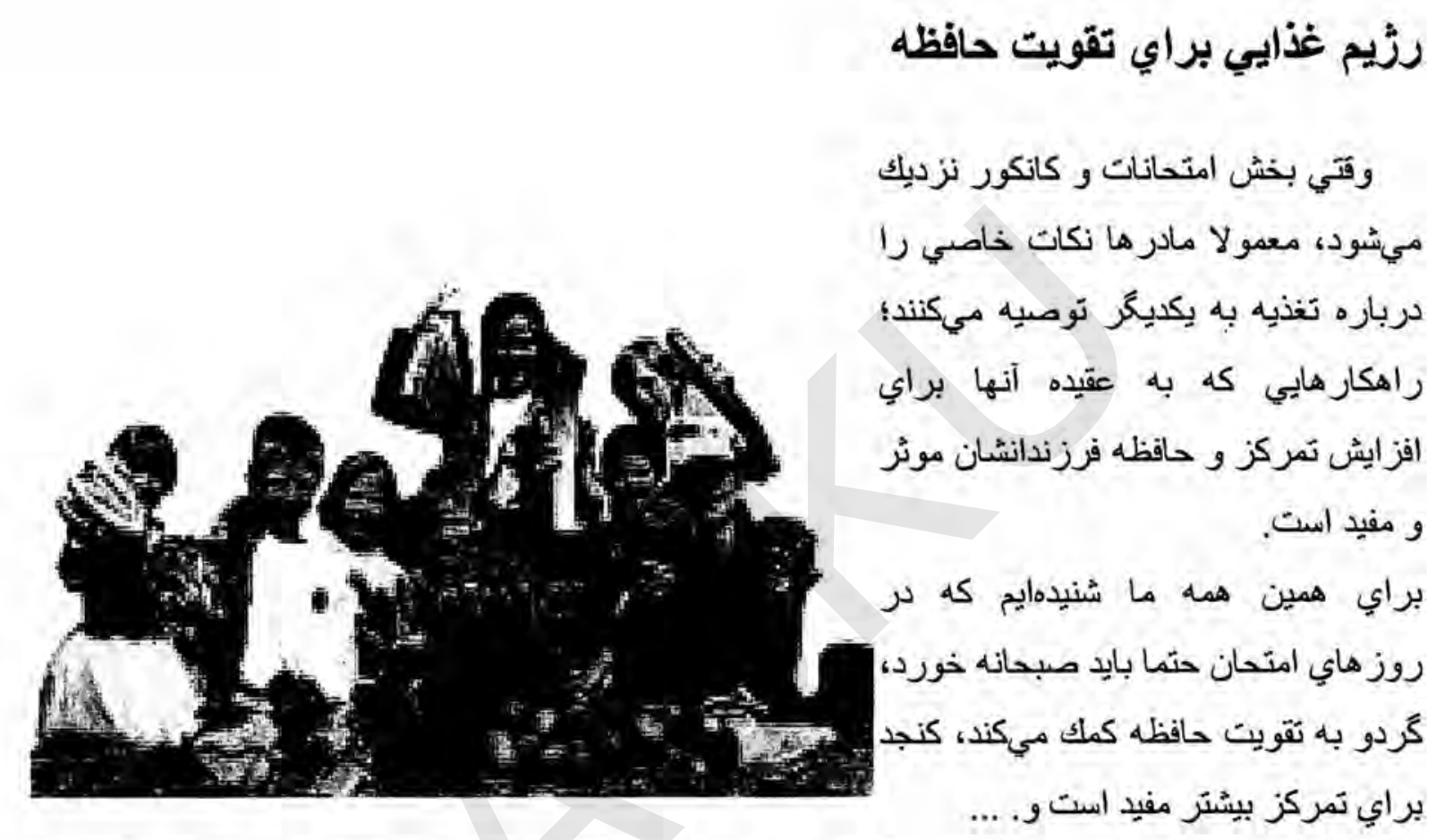

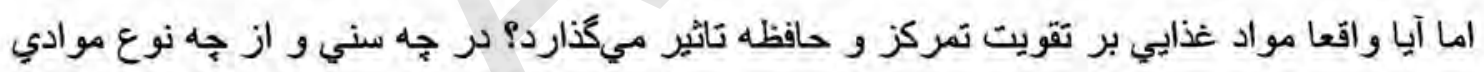

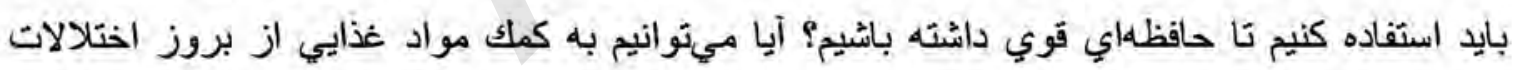
حافظه بيشخكيري كنيم؟

\section{خوردنى ها}

به طور كلى آنجه كه مهم است خورنى هاى است كه از طريق روايات براى تقويت حافظه به ما

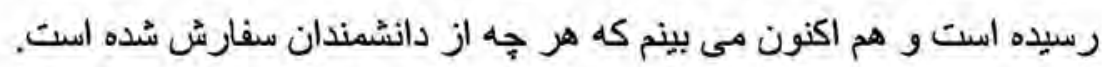

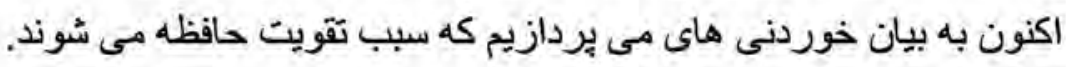

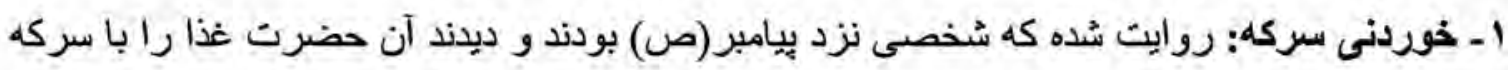

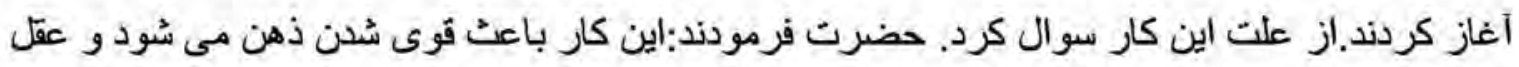
رازياد مى كند. r ـ انار: انار را با يبيه اش بخوريد كه همانا باعث بيبر استه شدن معده مى شود و حافظه رازياد مى كند. 
rا- خوردن عل :امام صادق(ع) فرموده :عسل شفاى هر دردى است و هر كس ناشتا بك انكشت عسل را بليسد بلغم را از بين مى برد و ذهنش را صفا مى دهد و باعث تقويت حافظه مى شود.

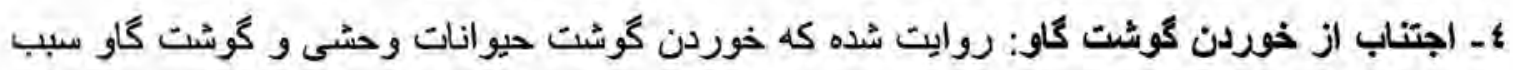

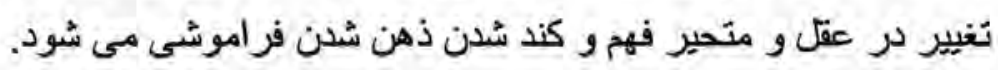

\section{ويتامين ها}

ويتامنى ها و تغذيه مناسب اثر بسزاى رر تقويت حافظه افراد به حصوص در كودكان دارد.اغلب

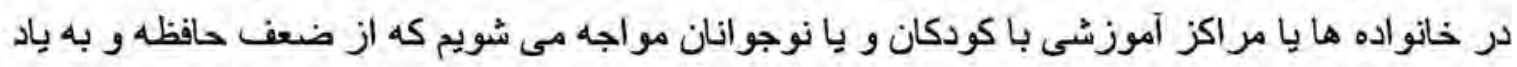

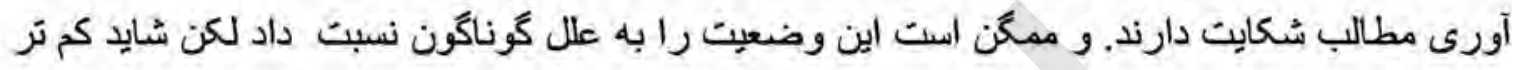

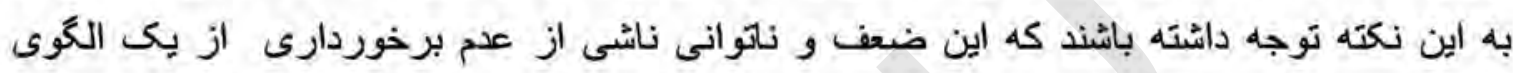

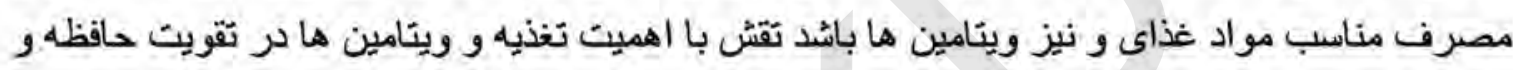

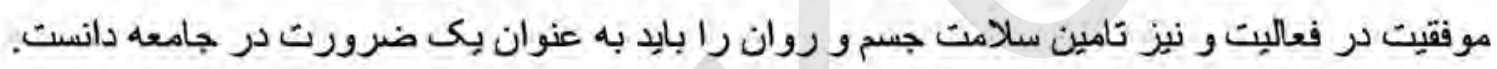

\section{ويتامين B B مجموعه ويتامين هاى كروه}

اين ويتامين انتقال جريان عصبى را تامين مى كند. در صورتى كه شخص به مقدار مناسب و كافى ستى

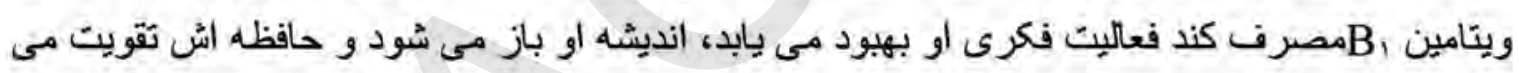
كردد.

نياز متوسط يكى فرد بزركسال به ويتامين B. ميلى كرم مر روز بوده در نوجوان، كاركز، خانم

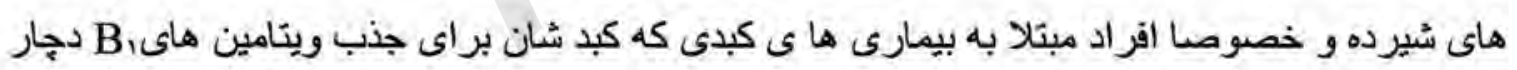

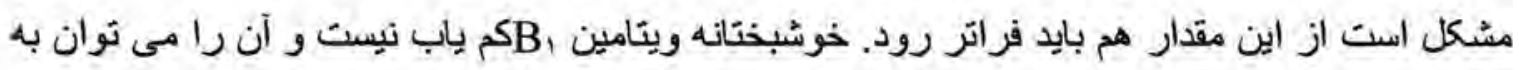

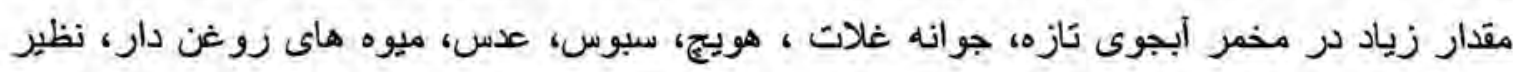

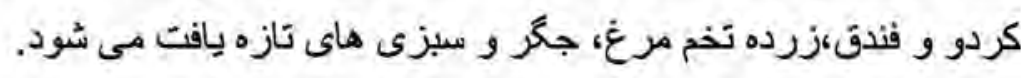

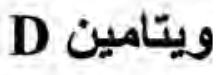

ويتامين D ماده ديكرى است كه بهتر است ان را ناديده نكيريم زيرا قسمت مهمى از عناصرى كه.

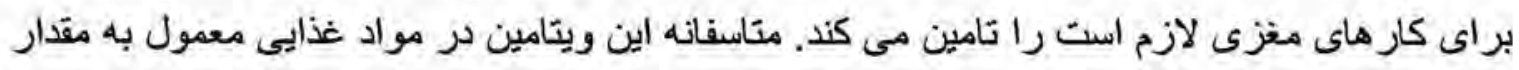

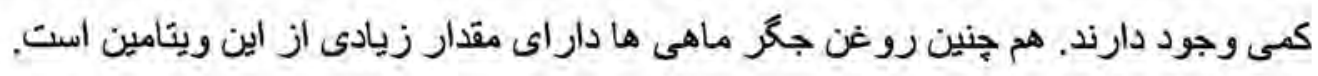




\section{ويتامين A}

به نظر نمى رسد كه اين ويتامين نقش ههمى درعملكرد فكرى حافظه داشنه باشد ولى به طور غير

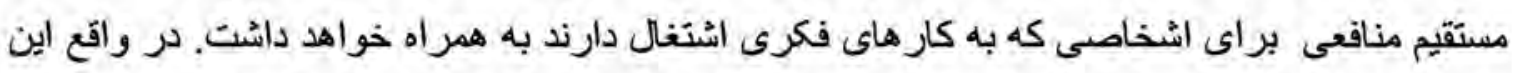

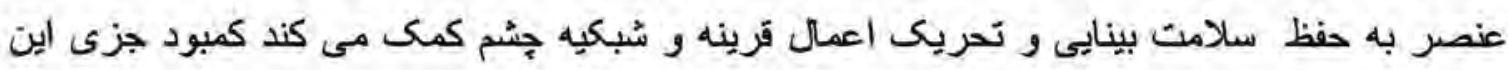

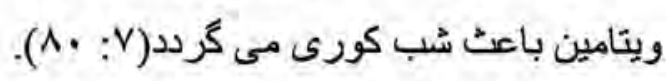

\section{تاثير ميوه هاو سبزى ها}

افر ادى كه از قدرث حافظه و يادكيرى خود رضايت ندارند با رعايت بعضى از نكات مى توانتد

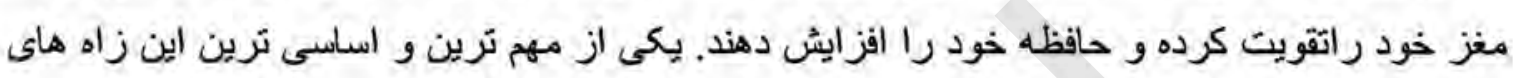
داشتن تغذيه صيحيح است. تحقيقات نشان داده كه ميوه ها و سيزيجات علاوه بر تندرسنى جسم بر سلامتى روح افراد نقش

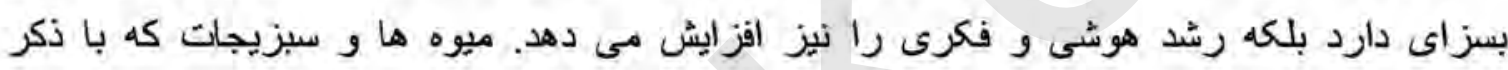

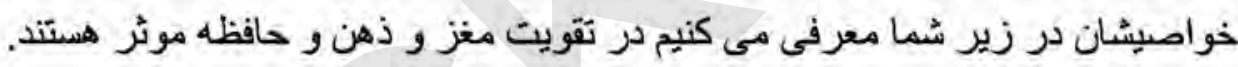

ا- سيب: سيب را يه عنوان ميوه اثى معجزه گر مى دانند.اين ميوه خاصيت خنثى كردن و از بين بردن

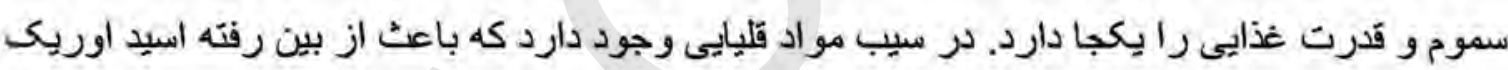

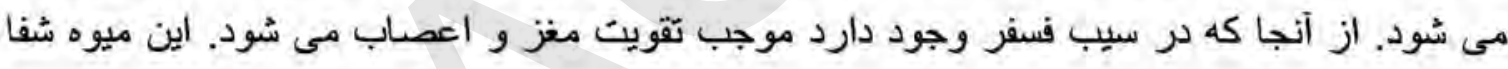

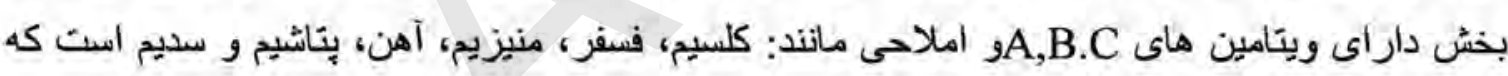
در رشد كودكان و حفظ قواى بدنى بزركسالان مفيد است.

افرادى كه احساس خستخى مفرط فشار هاى ذهنى و كمبود مواد معدنى دارند حتما روزانه از ميب

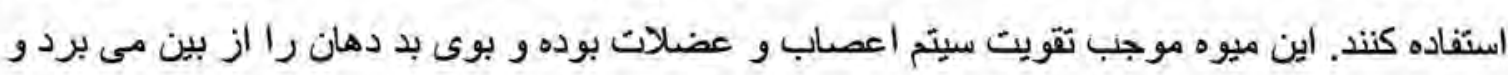

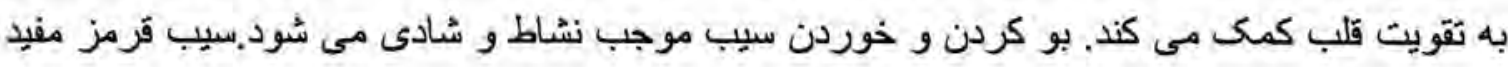
تر از سيب زرد است به شرطى كه تازه باتشد.

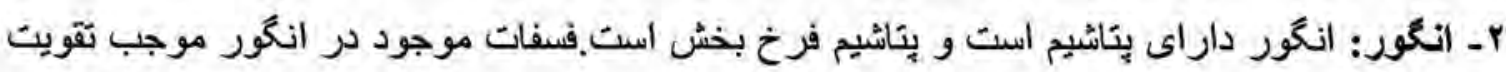

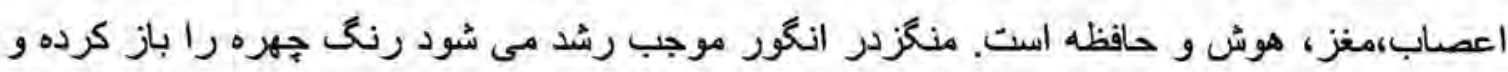

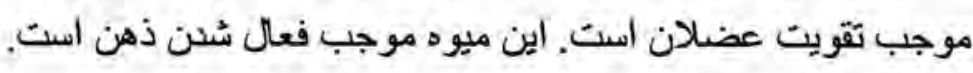

r- خرما: مقدار فسفر و كلسيم موجود در خرما با مقدار اين دو ماده در بدن ما برابرى مى كند اين ميوه. هوجب سرزندگى سلول هاى عصبى شُده و تقويت كنده مغز و كار هاى فئ فكرى است. 
عـ انجير: انجير كلسيم و فسفر فراوانى دارد كه باعث رشد استخوان ها رشد بيشتر و بهتر در

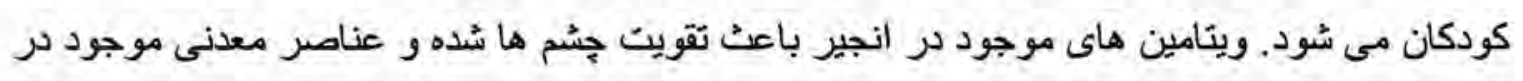

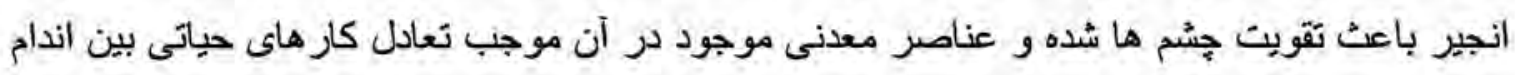

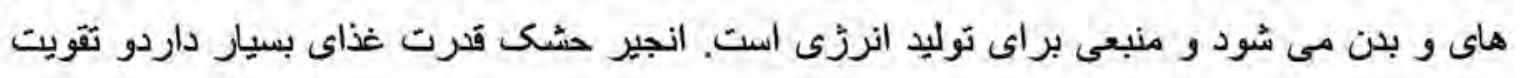

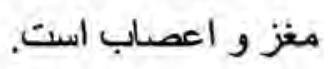
هـ انار: اين ميوه ذهن را تقويت مى كند و باكى كننده معده و روده است. سموم موجود در بدن را از

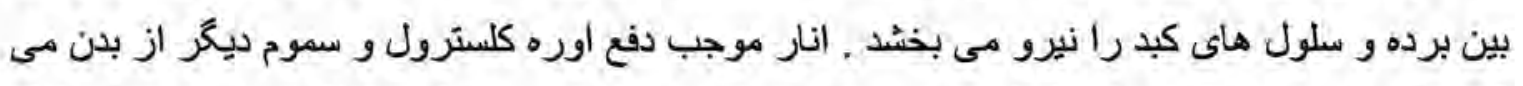

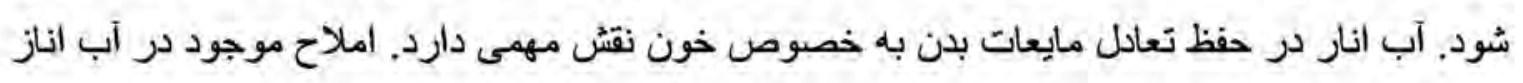
سريعا جذب بدن مي شود.

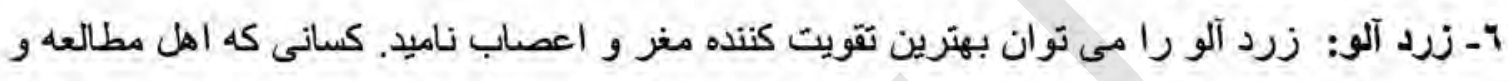

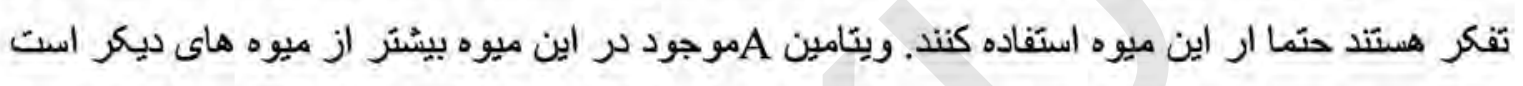

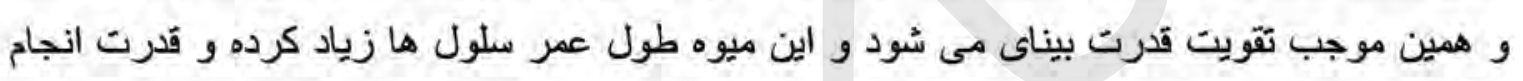

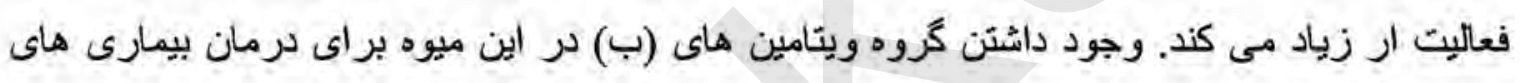

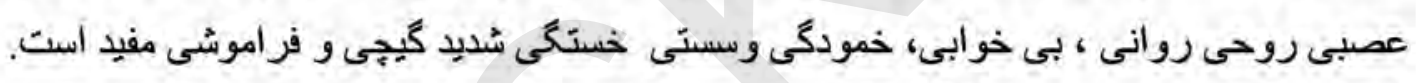

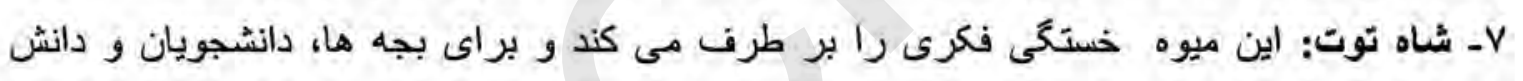

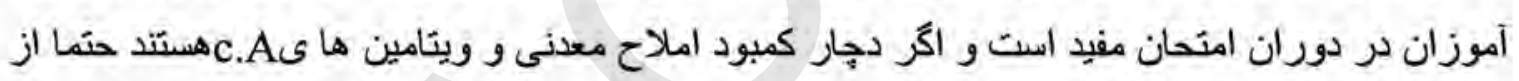
اين ميوه استفاده كثن.

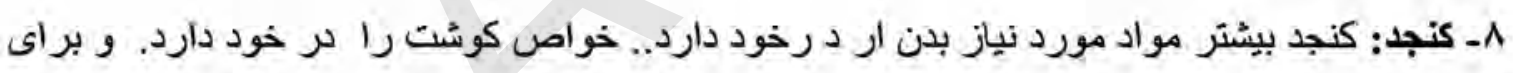

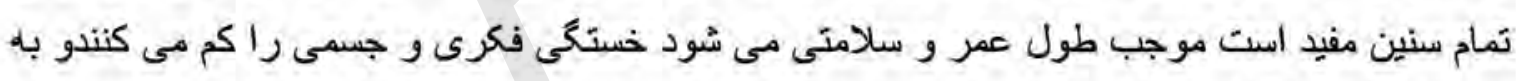
تقويت حافظه كمك مى كند

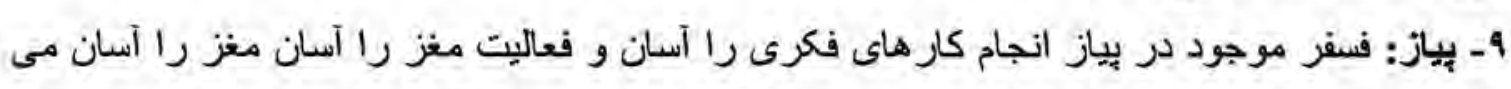

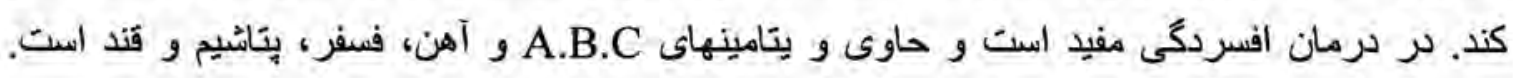

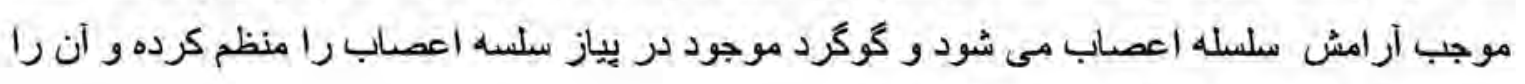

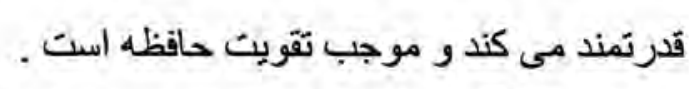

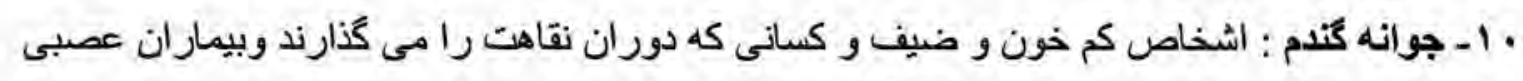

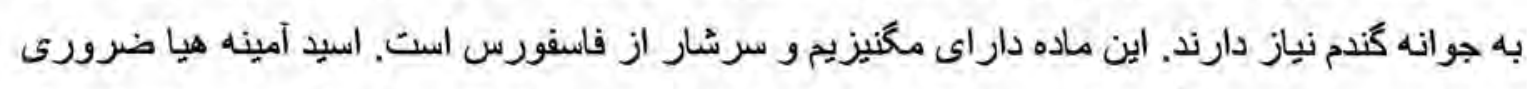

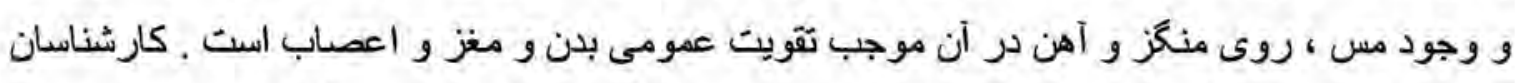

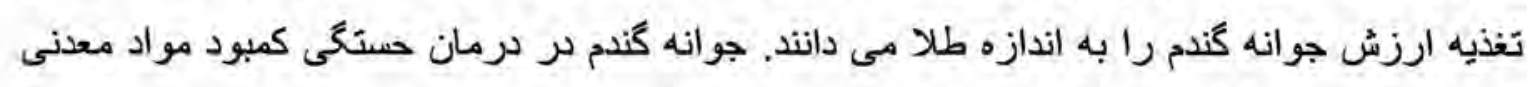

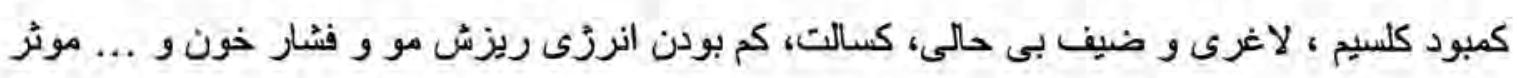


ا إـ عسل :عسل داراى همه ويتامين ها، املاح معدنى و آنزيم ها است و اين ماده براي سالخورده كان

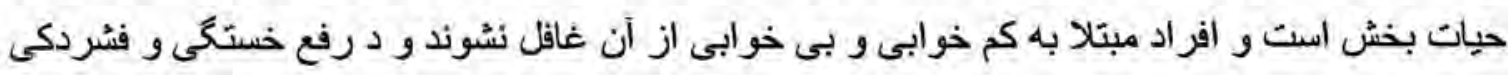

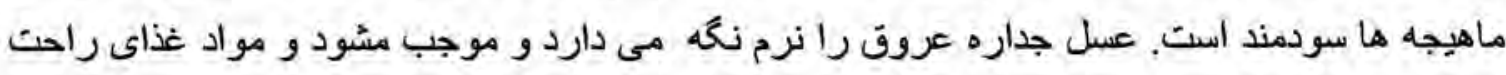

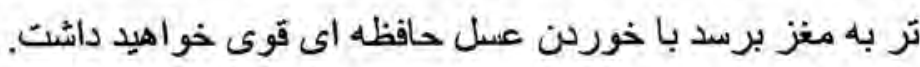

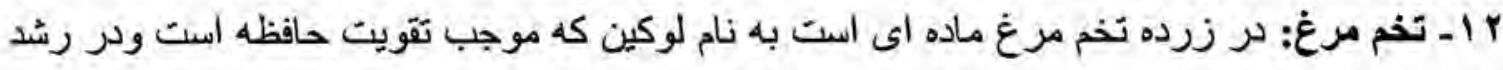

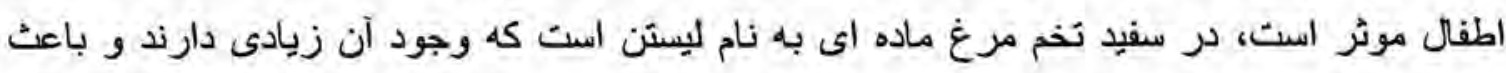

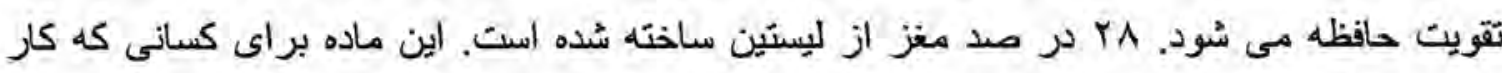

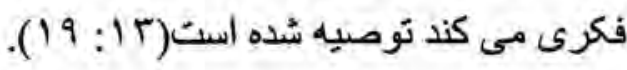

\section{تقويت حافظه از دوران جنيني}

ميترا زراتي، كارشناس ارشد تغذيه درباره اين موضوع به جامجم ميكويد: راكر بخواهِيح درباره

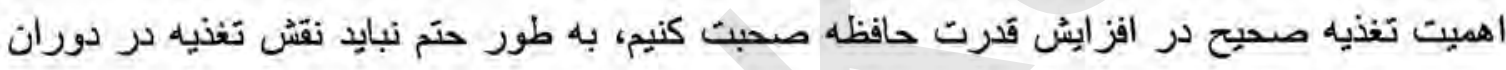

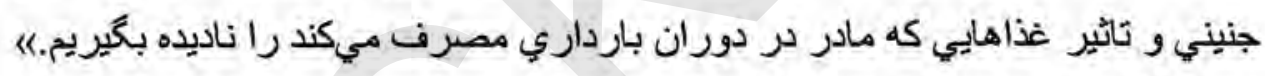

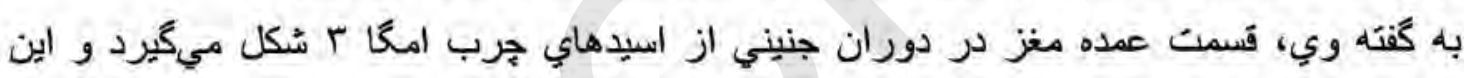

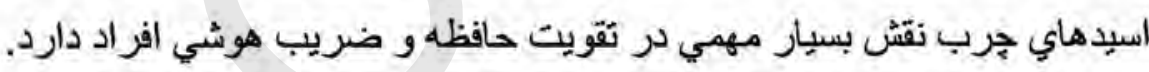

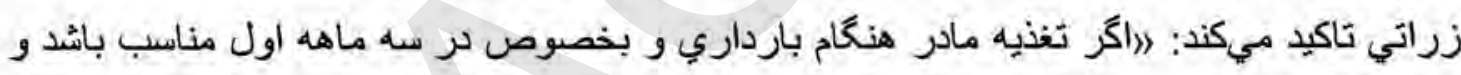

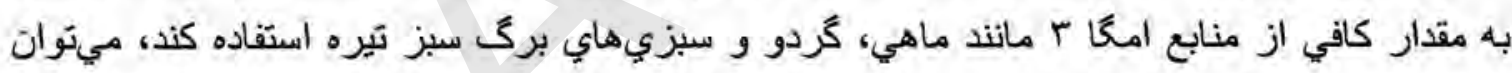

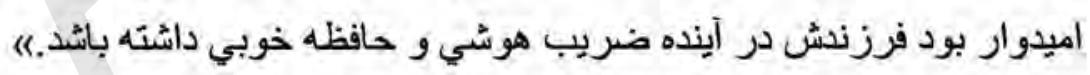

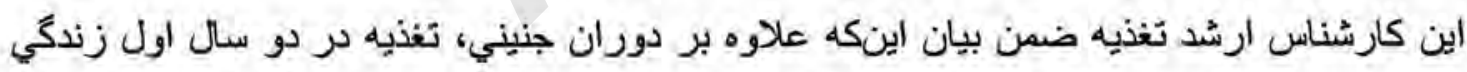

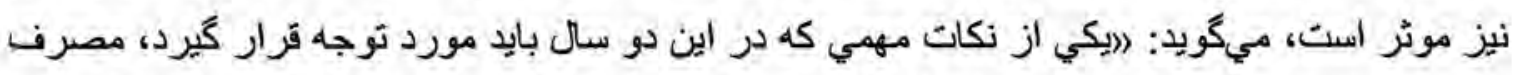

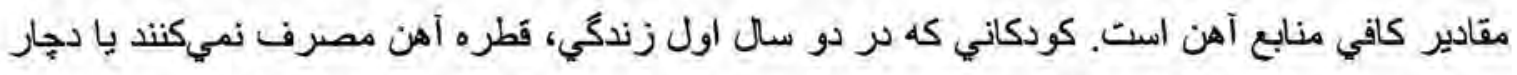

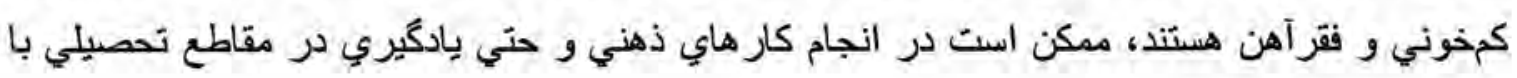

$$
\text { مشكل روبامرو شوند.ی }
$$

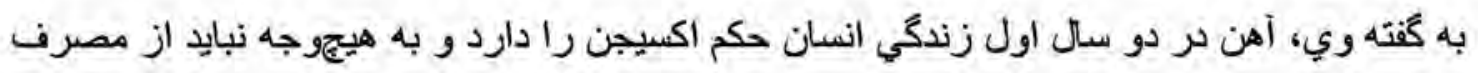

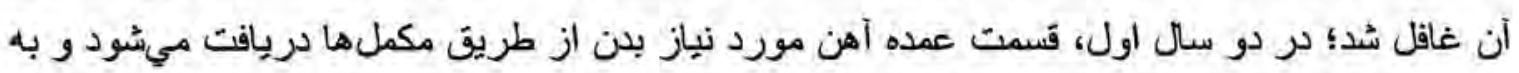
همين دليل نبايد در اين روند وقفهاي ايجاد كرد.

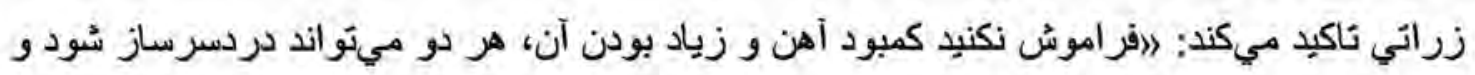

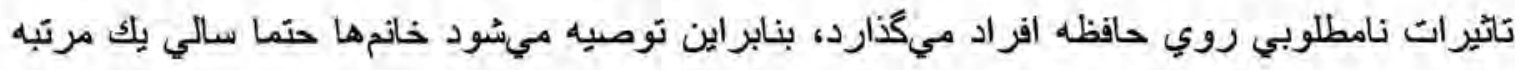

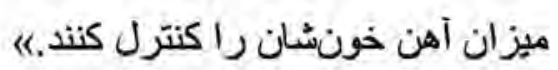


به كفته وي، بِ از له سالكي در صورتيكه از ميزان آهن خونتان اطلاعي نذاريد، خودسرانه از مكمل هاي حاوي آهن استفاده نكنيد.

\section{سرب و آلومينيوم؛ دشمنان حافظه}

بدون ترديد هيج كس دوست ندارد به بيماري آلزايمر مبتّلا شود و به همين دليل مردم هر كاري

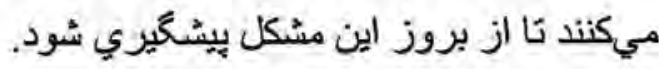

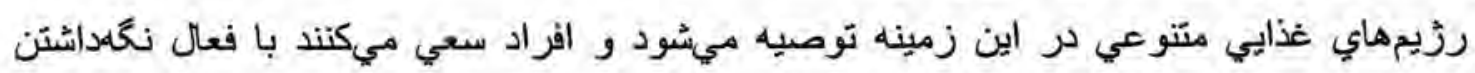

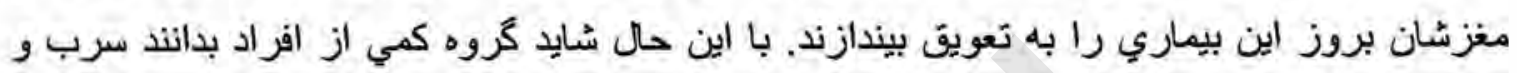

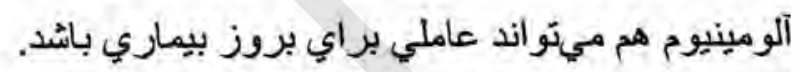

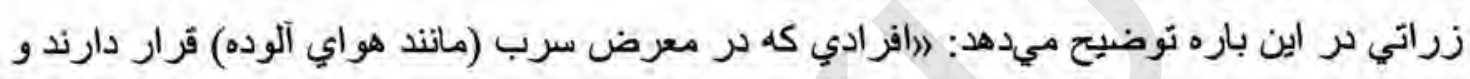

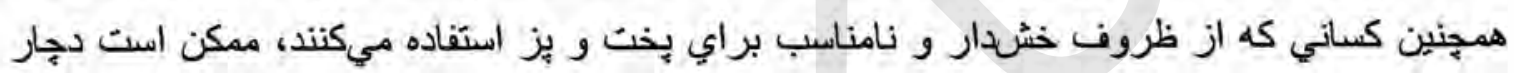
مسموميت با آلومينيوم و سرب شوند.ه وي تاكيد ميكند: (اوجود مقادير زياد سرب و آلومينيوم در سيستم مغزي، عصبي انسان ميتو اند او

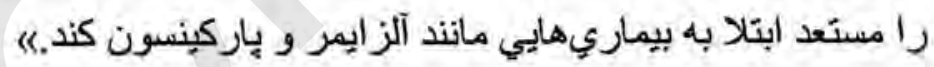

\section{تقويت حافظه به كمك خوراكي هاي رنغارنغ}

بارها متخصصان توصيه كردماند بيشتر از ميوهها و سبزيجات رنكي استفاده كنيد تا سالمثر بمانيد.

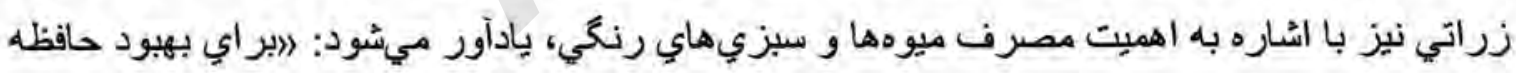

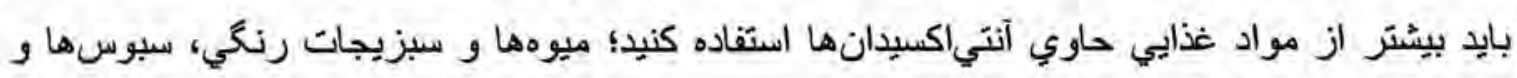

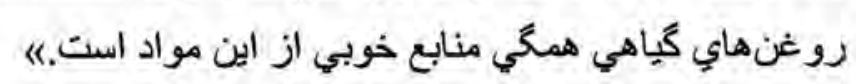

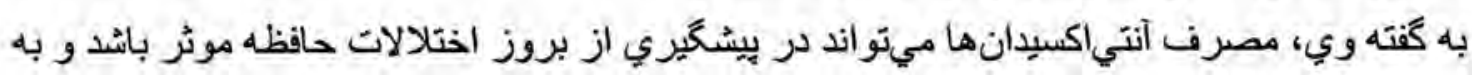

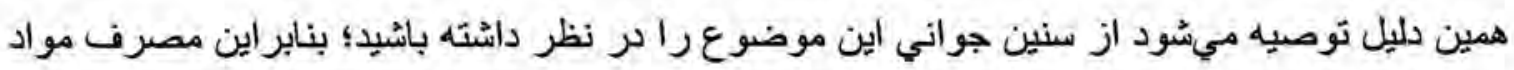

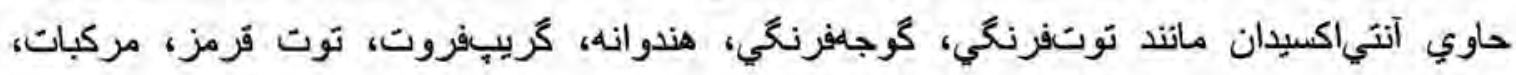

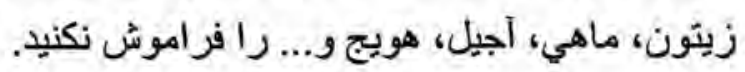

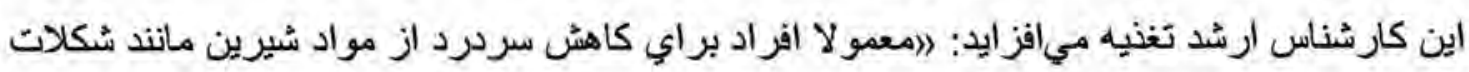

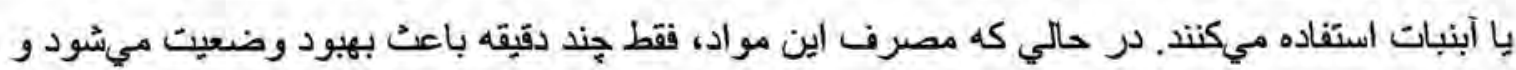

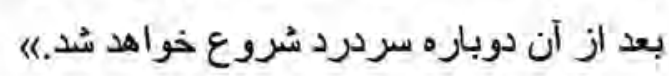


به كفته وي، براي بهيود حافظه در كوتاه مدت، بايد سعي كنيد قند خونتان را طوري تنظيم كنيد كه نوسان نداشته باشد؛ بنابراين رر جنين شرايطي به جاي اينكه از قندهاي ساده مانند شكلات و آبنبات كمك بكيريد، بهتر است از موادي استفاده كنيد كه همراه قند، حاوي فيير هم باشد تا از نوسانات قند خون جلو گيري كند؛ انواع ميوههاي خشك مانند توث يا انجير بهترين انتخاب در اين شرايط است. زراتي با اشاره به كروههاي خاصي كه بيشتر در معرض اختلالات حافظه قرار دارند، توضيح ميدهد: إبيمار ان مبتلا به ديابت در اين زمينه بايد دقت بيشتري داشتهه باثُند. مصرف بعضي از داروها نيز با اختلالات حافظه مرثبط است و به همبن دليل قبل از مصرف حثما بايد بركه راهنماي دارو مطالعه شود. افسردكي هم عاملي تاثيركذار بر قدرت حافظه است؛ به اين معني كه افراد افسرده، تمركز خوبي ندارند. علاوه بر اين، كودكان بيشفعال كروه ديكري هستند كه مدكن است با اختلالات حافظه و

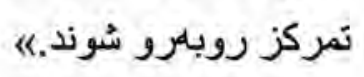

وي به افرادي كه از داروهاي لاغري غيرمجاز اسنفاده ميكند، هشدار ميدهد: 》(متاسفانه بسياري از دارو هايِي كه افراد به صورت غبر مجاز براي كاهش وزن استفاده ميكند نيز ميثو اند موجب بروز

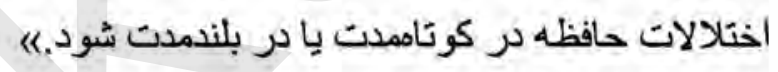

\section{هواي آلوده و كاهش ضريب هوشي}

به كَته اين كارشناس ارشد تغذيه، قرار كرفتن مر معرض دود ماشينها و آلودكي هوا يكي از علل بروز كمخوني فقر آهن است. بنابراين جنانجه شما هم در شهر هاي بزرگ و صنعتي زندكي ميكنيد و ناجاريد در هواي آلوده نفس بكشيد، بسيار مهم است كه هر از كاهي ميزان آهن خونتان را كنترل كنيد. وي تاكيد ميكند: خانو ادهايِي كه به بهانه فوايد شير، بيش از حد نياز به كودك شير ميدهند نيز ممكن است با اين مشكل روبهرو شوند، جون دريافت زياد كلسيم از طريث شير ميثو اند موجب كاهش جذب آهن شُود.

زراتي تاكيد ميكند: افراد جاق و كساني كه سيحار ميكشند يا در معرض دود آن قرار دارند، بيشتر احتمال دارد با اختلالات حافظه روبامرو شوند. به همين دليل كاهش وزن و ترك سيگار شيوههايي موثر براي بيشگيري از بروز مشكل است. همجنين اكر اطر افيان شما سيخار ميكشند و نميثو انيد كاري در

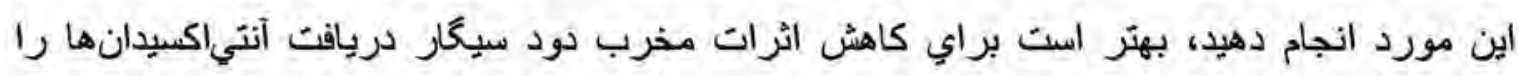
افزايش دهيد. صبحانه همجنان در تقويت حافظه رول مهم را دارا ميباشد. زراتي با اشاره به اهميت مصرف صبحانه، توضيح ميدهد: كرسنكي بيشتر از هشت ساعث ميتواند نقش موثري در كاهش قدرت حافظه 


\section{نتيجه كيرى}

حافظه يكى از موضوعات مهم است كه در اين مونوكراف بطور واضح براى تان بيان نمودم البته

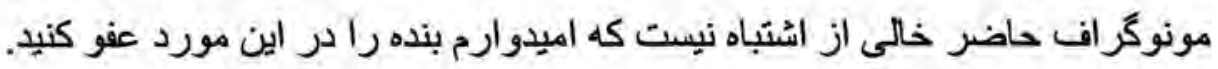

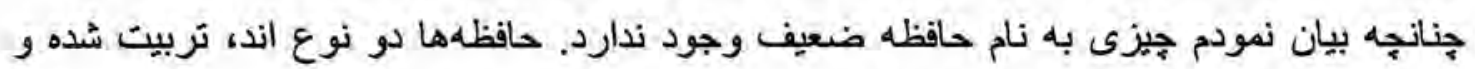

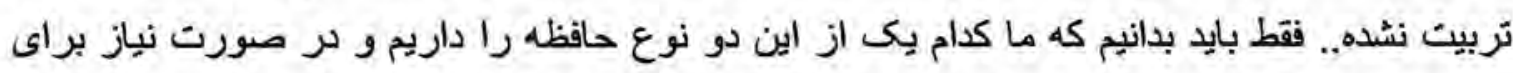

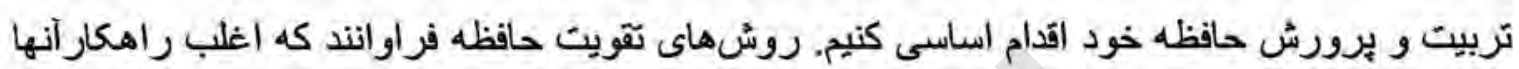

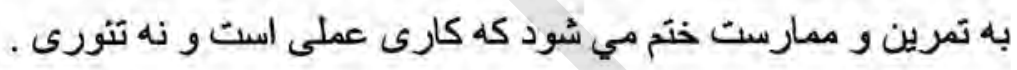

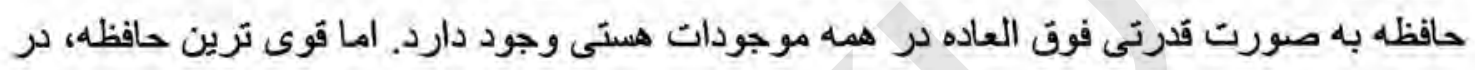

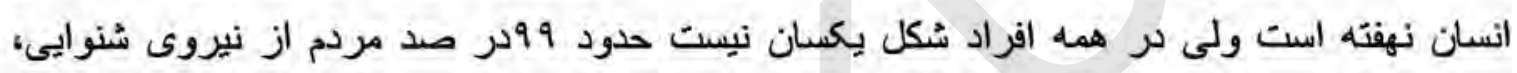

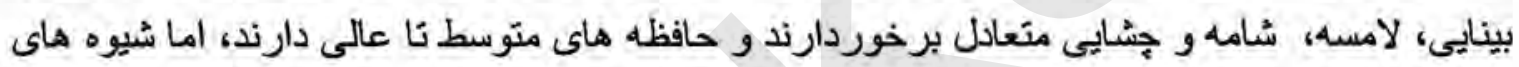

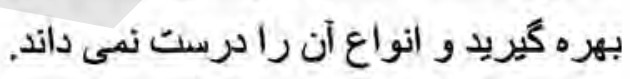

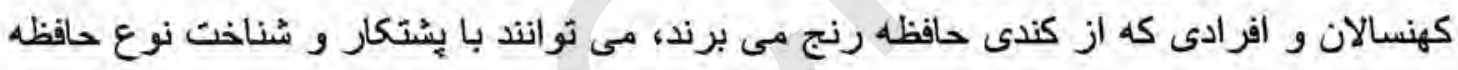

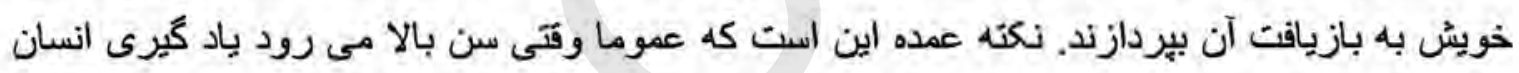

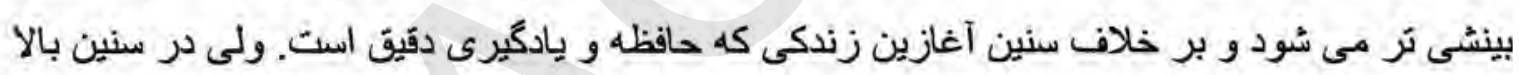

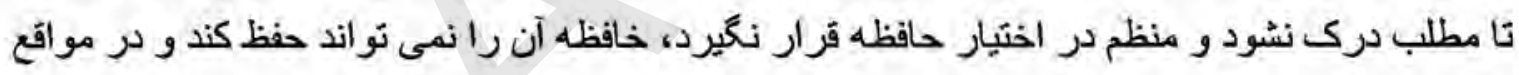
لزوم تحويل دهد.

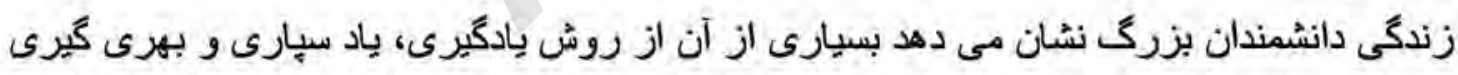

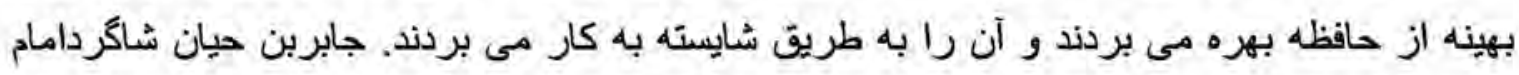

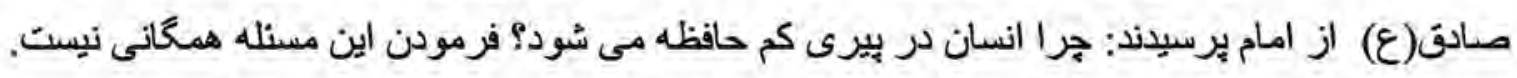

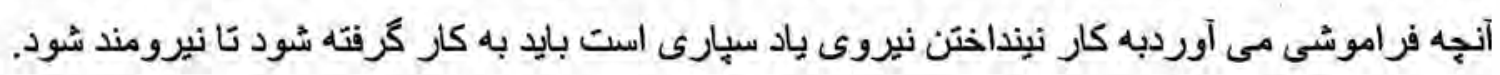

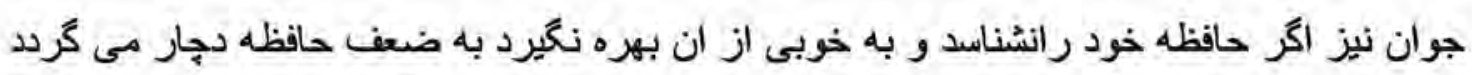

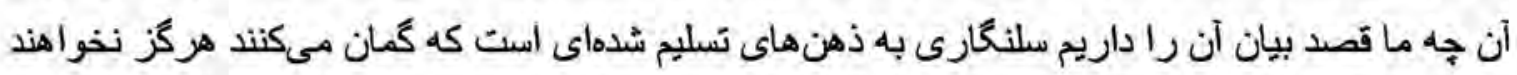

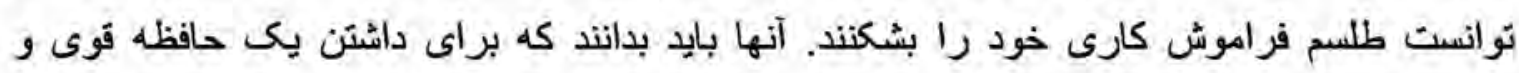
نيرومند، لازم است زحمت بكشند و با روشهاى علمى و مجرب، از سرمايه وجودى خود استفاده كنند .

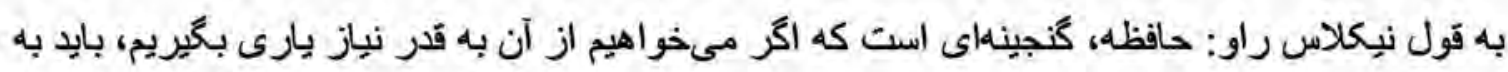
أن بها بدهيِ و برايش سرمايه كذارى كنيم. 


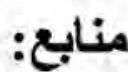

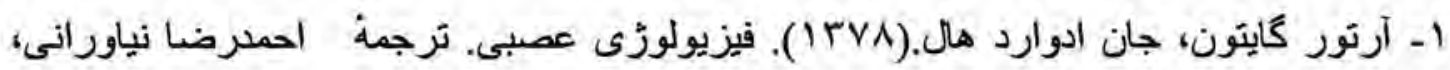

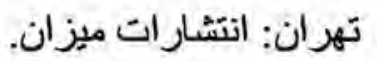

Y- احمدى، علىاصغر و محمدتقى فر اهانى.(ITVY). روانشناسى عمومى. تهران: مركز تربيت معلم.

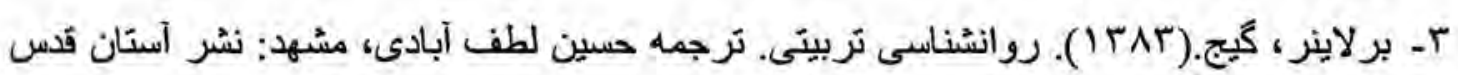
رضوى.

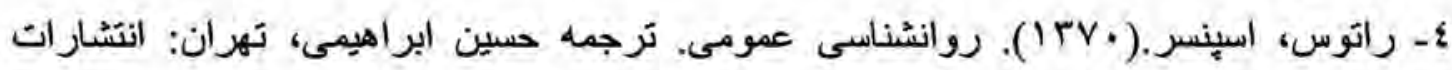
ساورالان.

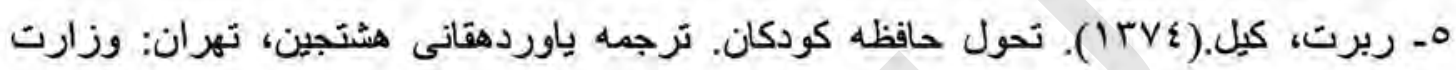
فرهن و ارشاد اسلامى، سازمان جابِ و انتشار ات.

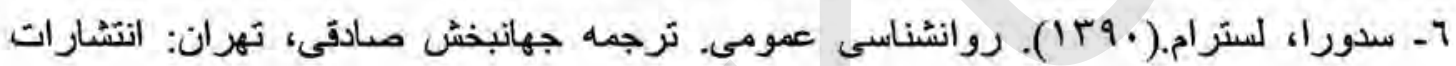

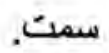

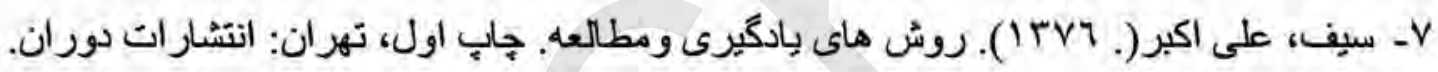

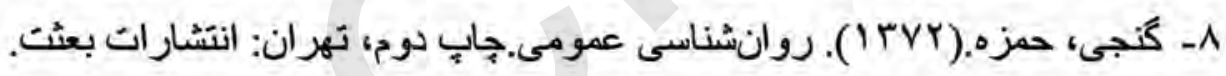

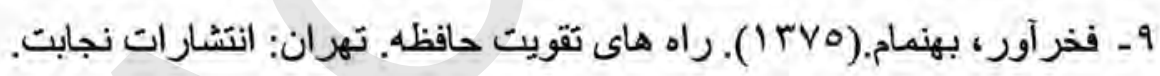

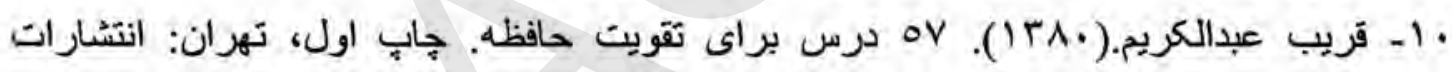

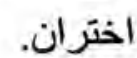

1)

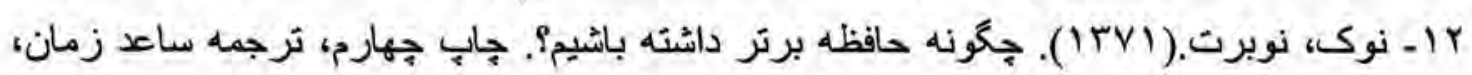

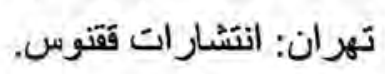

rا - نياورانى، احمد رضا.(IrVo) راهنتان 


$$
\begin{aligned}
& 100
\end{aligned}
$$

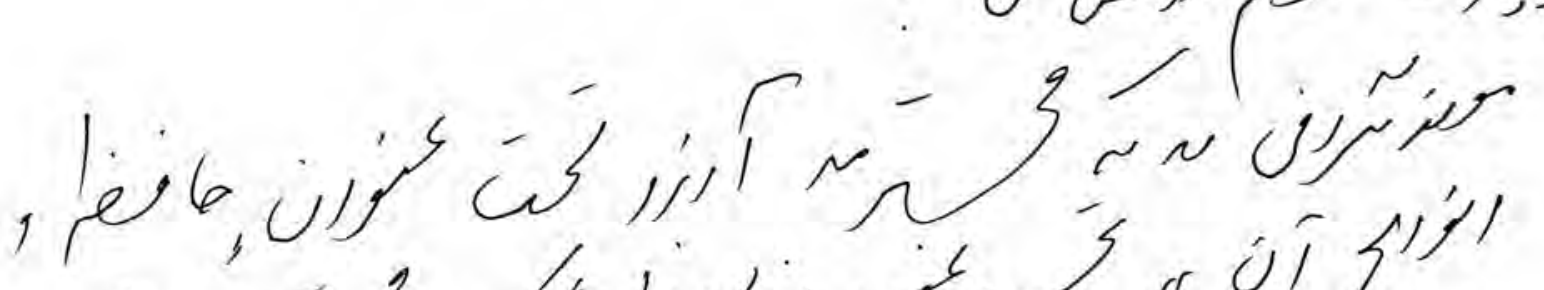

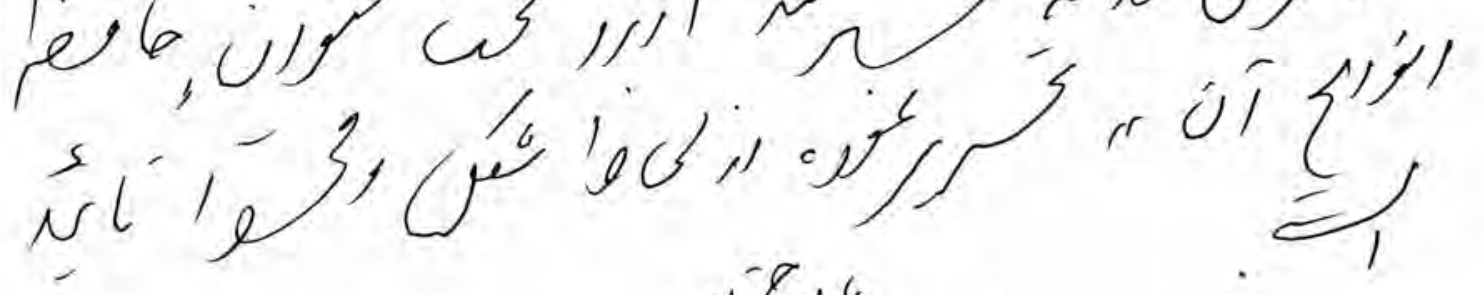

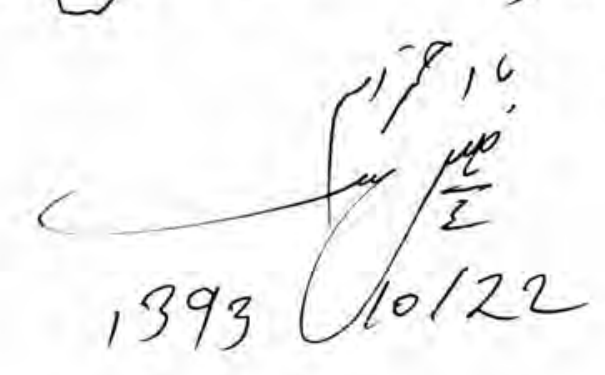

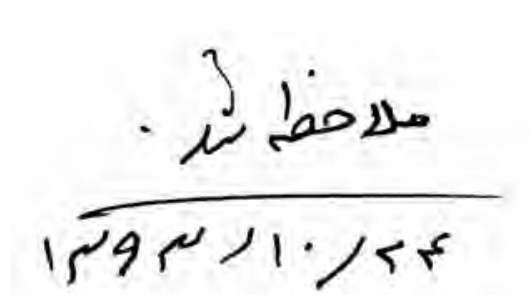

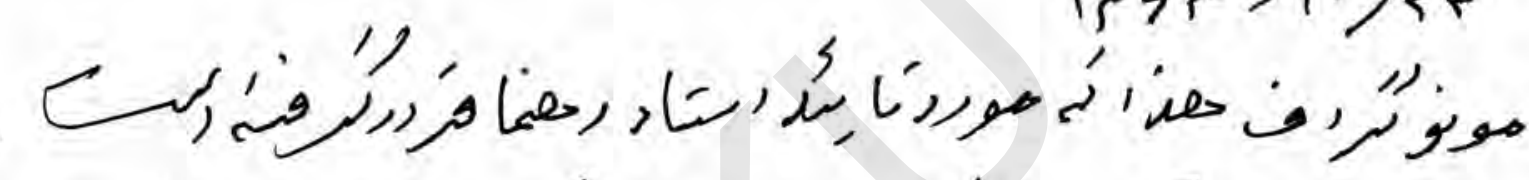
ए"

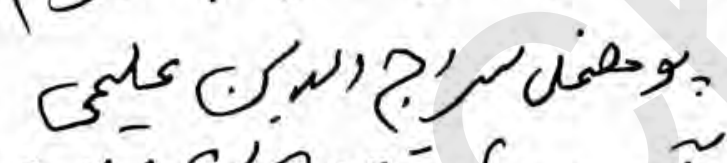

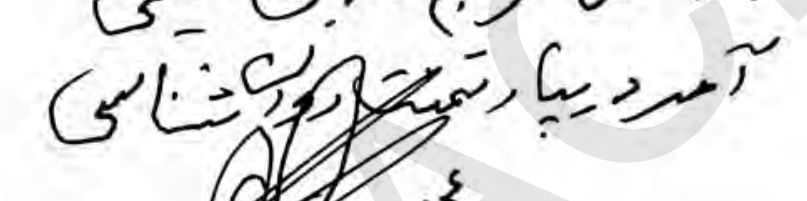

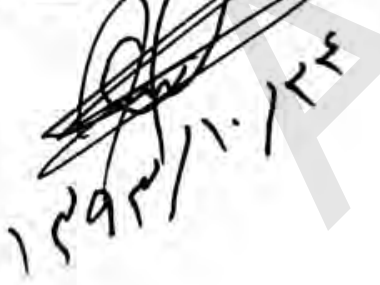

$$
\begin{aligned}
& 18,5,350 \\
& \text { Es ine } \\
& \text { - } \\
& \text { 393 to tan }
\end{aligned}
$$

